\title{
HYDROGEOLOGY AND SIMULATION OF GROUND- WATER FLOW, PICATINNY ARSENAL AND VICINITY, MORRIS COUNTY, NEW JERSEY
}

By Lois M. Voronin and Donald E. Rice

U.S. GEOLOGICAL SURVEY

Water-Resources Investigations Report 96-4061

Prepared in cooperation with the

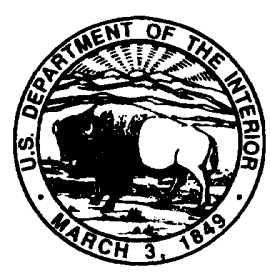

U.S. ARMY ARMAMENT RESEARCH DEVELOPMENT AND ENGINEERING CENTER

West Trenton, New Jersey 


\title{
U.S. DEPARTMENT OF THE INTERIOR \\ BRUCE BABBIT, Secretary
}

\author{
U. S. GEOLOGICAL SURVEY
}

Gordon P. Eaton, Director

For additional information write to:

District Chief

U. S. Geological Survey

Mountain View Office Park

810 Bear Tavern Road

Suite 206

West Trenton, NJ 08628
Copies of this report can be purchased from:

U. S. Geological Survey

Earth Science Information Center

Open-File Reports Section

Box 25286, MS 517

Denver Federal Center

Denver, CO 80225-0046 


\section{CONTENTS}

Abstract

Page

Abstran

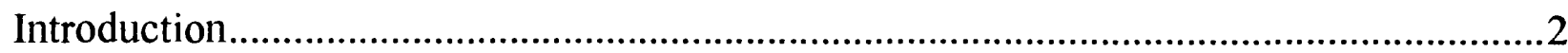

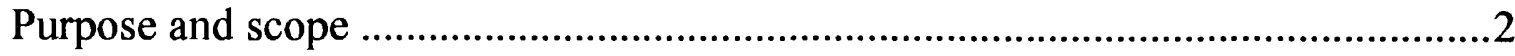

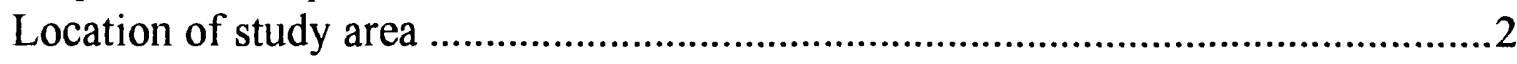

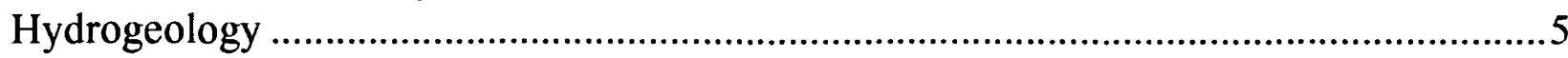

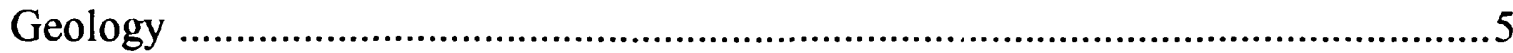

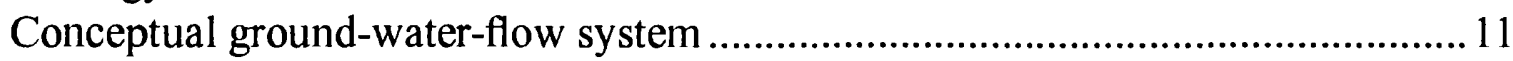

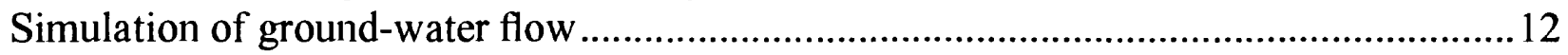

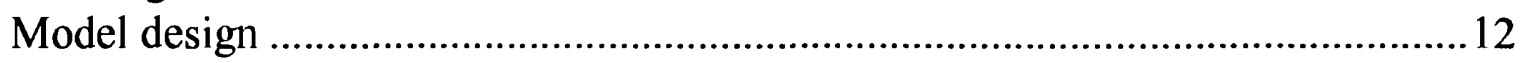

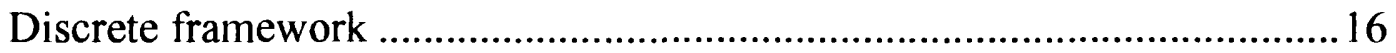

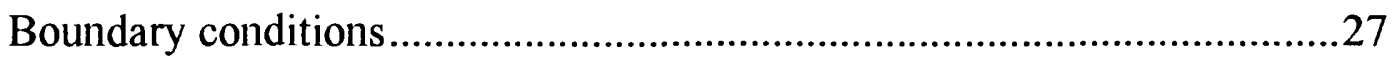

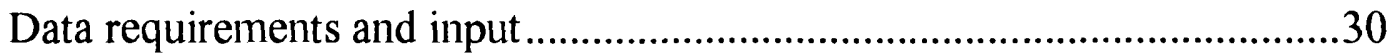

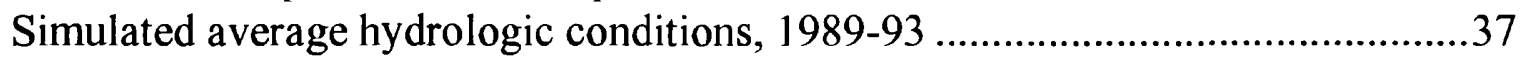

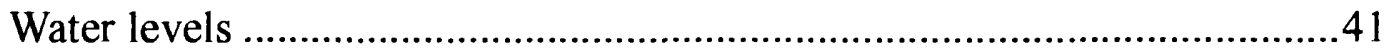

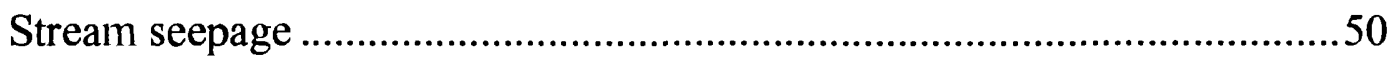

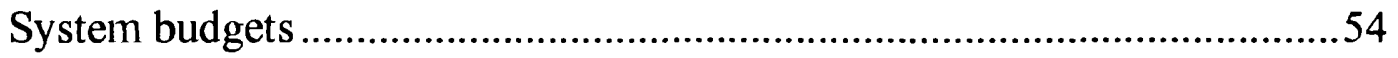

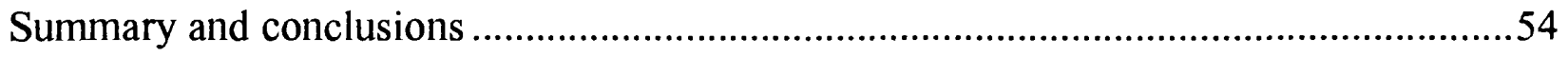

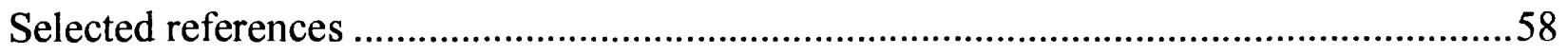

\section{ILLUSTRATIONS}

Plate 1. Location of streamflow-measurement sites, January 19 and 20, 1993, and wells used to calibrate the valley-wide ground-water-flow model, Picatinny Arsenal, New Jersey in pocket

Figure 1. Location of Picatinny Arsenal, New Jersey................................................. 3

2. Map showing the area of the valley-wide ground-water-flow model and locations of hydrogeologic sections, selected observation wells, streamflow-gaging stations, and water-supply wells, Picatinny Arsenal and vicinity, New Jersey.

3-4. Maps showing:

3. Physical features in the vicinity of Picatinny Arsenal, New Jersey ......6

4. Bedrock geology of Picatinny Arsenal, New Jersey ..............................8

5. Hydrogeologic section A - A' (down the valley), Picatinny Arsenal,

New Jersey

6. Hydrogeologic section B - B' (across the valley), Picatinny Arsenal,

New Jersey

7. General hydrogeologic sections through the ground-water-flow system at Picatinny Arsenal, New Jersey (A) north of First Street and (B) at the southern boundary of the arsenal 


\section{ILLUSTRATIONS--Continued}

Figure 8. Water-level hydrograph of wells at the landfill at Picatinny Arsenal,

New Jersey, June 1985 through March 1987

Page

9. Map showing finite-difference grid used to simulate ground-water flow

at Picatinny Arsenal and vicinity, New Jersey.... 14

10. Section A - A' (down the valley) showing model layers used in the valley-

wide ground-water-flow model, Picatinny Arsenal, New Jersey.

11-18. Maps showing thickness of:

11. Model layer A1, Picatinny Arsenal and vicinity, New Jersey

12. Model layer A2, Picatinny Arsenal and vicinity, New Jersey

13. Model layer A3, Picatinny Arsenal and vicinity, New Jersey 21

14. Model layer A4, Picatinny Arsenal and vicinity, New Jersey .22

15. Model layer A5, Picatinny Arsenal and vicinity, New Jersey .23

16. Model layer $\mathrm{Cl}$, Picatinny Arsenal and vicinity, New Jersey .24

17. Model layer C2, Picatinny Arsenal and vicinity, New Jersey ..............25

18. Model layer C3, Picatinny Arsenal and vicinity, New Jersey ..............26

19. Map showing finite-difference grid and location of model boundaries for the water-table aquifer used in the valley-wide ground-waterflow model, Picatinny Arsenal and vicinity, New Jersey..... 28

20. Diagrammatic vertical section showing model boundaries used in the valleywide ground-water-flow model, Picatinny Arsenal and vicinity, New Jersey

21-25. Maps showing areal distribution of horizontal hydraulic conductivities used to simulate ground-water flow in:

21. Model layer A1, Picatinny Arsenal and vicinity, New Jersey.............32

22. Model layer A2, Picatinny Arsenal and vicinity, New Jersey ...............33

23. Model layer A3, Picatinny Arsenal and vicinity, New Jersey..............34

24. Model layer A4, Picatinny Arsenal and vicinity, New Jersey..............35

25. Model layer A5, Picatinny Arsenal and vicinity, New Jersey ...............36

26-27. Maps showing areal distribution of vertical hydraulic conductivities used to simulate ground-water flow in:

26. Model layer C1, Picatinny Arsenal and vicinity, New Jersey ..............38

27. Model layer C2, Picatinny arsenal and vicinity, New Jersey ...............39

28. Water-level hydrograph of well 27-95 (9C), June 1988-March 1993,

and water level measured on January 20, 1993, Picatinny Arsenal,

New Jersey

29-34. Maps showing simulated potentiometric surface of:

29. Model layer A1, Picatinny Arsenal and vicinity, New Jersey 42

30. Model layer A2, Picatinny Arsenal and vicinity, New Jersey 43

31. Model layer A3, Picatinny Arsenal and vicinity, New Jersey .44 


\section{ILLUSTRATIONS--Continued}

Figures--Continued

Page

29-34. Maps showing simulated potentiometric surface of--Continued:

32. Model layer A4, Picatinny Arsenal and vicinity, New Jersey 45

33. Model layer A5, Picatinny Arsenal and vicinity, New Jersey 46

34. Model layer A6, Picatinny Arsenal and vicinity, New Jersey

35. Map showing steady-state simulated flow at each model node for Bear Swamp Brook, Green Pond Brook, and the Rockaway River, Picatinny Arsenal and vicinity, New Jersey 53

\section{TABLES}

Table 1. Stratigraphic and geohydrologic characteristics of geologic units at Picatinny Arsenal, New Jersey

2. Wells and types of data used to delineate the hydrologic units at Picatinny Arsenal and vicinity, New Jersey.

3. Simulated and measured water levels for wells measured during January 20-22, 1993, for all simulated aquifers, Picatinny Arsenal, New Jersey

4. Steady-state simulated flows for selected reaches and measured discharge at selected sites, Green Pond Brook, Picatinny Arsenal, New Jersey .......52

5. Simulated steady-state ground-water budget of the glacial sediments and bedrock aquifer at Picatinny Arsenal and vicinity, New Jersey 


\section{CONVERSION FACTORS AND VERTICAL DATUM}

Multiply

foot (ft)

mile (mi)
By

Length

0.3048

1.609

Area

square foot $\left(\mathrm{ft}^{2}\right)$

square foot $\left(\mathrm{ft}^{2}\right)$

square mile $\left(\mathrm{mi}^{2}\right)$

gallon (gal)

gallon (gal)

cubic foot $\left(\mathrm{ft}^{3}\right)$

cubic foot per second $\left(\mathrm{ft}^{3} / \mathrm{s}\right)$

gallon per minute (gal $/ \mathrm{min}$ )

gallon per day (gal/d)

million gallons per day (Mgal/d)

Hydraulic conductivity

foot per day $(\mathrm{ft} / \mathrm{d})$

0.3048

\section{Transmissivity}

square foot per day $\left(\mathrm{ft}^{2} / \mathrm{d}\right)^{1}$
929.0

0.09294

2.590

Volume

3.785

0.003785

0.02832

Flow

0.02832

0.06308

0.003785

0.04381
0.09290 $\underline{\text { To obtain }}$

meter

kilometer

square centimeter

square meter

square kilometer

cubic meter

cubic meter

cubic meter per second liter per second cubic meter per day cubic meter per second square meter per day

Sea level: In this report "sea level" refers to the National Geodetic Vertical Datum of 1929-- a geodetic datum derived from a general adjustment of the first-order level nets of the United States and Canada, formerly called Sea Level Datum of 1929.

${ }^{1}$ This unit is used to express transmissivity, the capacity of an aquifer to transmit water. Conceptually transmissivity is cubic feet (of water) per day per square foot ( of aquifer area) times feet (of aquifer thickness), or $\left(\mathrm{ft}^{3} / \mathrm{d}\right) / \mathrm{ft}^{2} \times \mathrm{ft}$. In this report, this expression is reduced to its simplest form, $\mathrm{ft}^{2} / \mathrm{d}$. 


\title{
HYDROGEOLOGY AND SIMULATION OF GROUND-WATER FLOW, PICATINNY ARSENAL AND VICINITY, MORRIS COUNTY, NEW JERSEY
}

\author{
By Lois M. Voronin and Donald E. Rice
}

\begin{abstract}
Ground-water flow in glacial sediments and bedrock at Picatinny Arsenal, N.J., was simulated by use of a three-dimensional finite-difference ground-water-flow model. The modeled area includes a 4.3-square-mile area that extends from Picatinny Lake to the Rockaway River. Most of the study area is bounded by the natural hydrologic boundaries of the ground-water system.

Geophysical logs, lithologic logs, particle-size data, and core data from selected wells and surface geophysical data were analyzed to define the hydrogeologic framework. Hydrogeologic sections and thickness maps define six permeable and three lowpermeability layers that are represented in the model as aquifers and confining units, respectively.

Hydrologic data incorporated in the model include a rate of recharge from precipitation of 22 inches per year, estimated from long-term precipitation records and estimates of evapotranspiration. Additional recharge from infiltration along valleys was estimated from measured discharge of springs along the adjacent valley walls and from estimates of runoff from upland drainage that flows to the valley floor. Horizontal and vertical hydraulic conductivities of permeable and low-permeability layers were estimated from examination of aquifer-test data, gamma-ray logs, borehole cuttings, and previously published data. Horizontal hydraulic conductivities in glacial sediments range from 10 to 380 feet per day. Vertical hydraulic conductivities of the low-permeability layers range from 0.01 to 0.7 feet per day.
\end{abstract}

The model was calibrated by simulating steady-state conditions during 1989-93 and by closely matching simulated and measured ground-water levels, vertical groundwater-head differences, and streamflow gain and loss. Simulated steady-state potentiometric-surface maps produced for the six permeable layers indicate that ground water in the unconfined material within Picatinny Arsenal flows predominantly toward the center of the valley, where it discharges to Green Pond Brook. Beneath the upper confining unit, ground water flows southwestward, down the valley. Between First Street and Farley Avenue, the upper confining unit pinches out near the valley walls, resulting in 
a major input of water to, and causing a local potentiometric high in, the underlying aquifer layers. Ground-water-flow directions southwest of the southern arsenal boundary are predominantly to the Rockaway River.

\section{INTRODUCTION}

Picatinny Arsenal (fig. 1) has been a site of the manufacture of explosives since the mid-1800's and, in 1908, was designated a U.S. Army Arsenal. The ground-water resources of the arsenal area are affected by numerous point sources of contamination as a result of these activities (Benioff and others, 1991). Effective resource management, which can minimize these problems, requires definition of the regional hydrogeologic framework and ground-water-flow system. Therefore, the U.S. Geological Survey began a study in cooperation with the U.S. Army Armament Research Development and Engineering Center. The objectives of this study were to (1) describe the hydrogeologic framework of Picatinny Arsenal and vicinity and (2) construct a valley-wide groundwater-flow model that simulates the ground-water-flow system in a $4.3-\mathrm{mi}^{2}$ area centered on the arsenal (fig. 2). This model integrates all available hydrologic data for Picatinny Arsenal and vicinity into a consistent representation of the flow system. The results of the ground-water-flow simulation can be used as a tool to evaluate potential advective transport of contaminants throughout the valley.

\section{Purpose and Scope}

This report describes the development and application of the ground-water-flow model for the Picatinny Arsenal area. Specifically, the report describes (1) the hydrogeologic framework at Picatinny Arsenal and vicinity, (2) the conceptual hydrogeologic model used to simulate the ground-water-flow system in the modeled area, (3) the methods and approach used to simulate ground-water flow, and (4) the results of the flow simulations.

The report includes (1) hydrogeologic sections; (2) thickness maps of the permeable and low-permeability layers; (3) maps of horizontal and vertical hydraulic conductivities for the permeable and low-permeability layers, respectively;(4) a map of simulated flow between the glacial sediments and Bear Swamp Brook, Green Pond Brook, and the Rockaway River; (5) a table of ground-water budgets; and (6) maps of potentiometric surfaces in the permeable layers.

\section{Location of Study Area}

Picatinny Arsenal is just north of the Wisconsin terminal moraine in north-central New Jersey, in the Highlands Physiographic Province (fig. 1). The arsenal is situated in an elongated valley that extends northeast-southwest. The valley is bounded by Green Pond 


\section{EXPLANATION}

Picatinny Arsenal boundary

Note: Broken drainage lines at

Bear Swamp Brook indicate flow through underground culverts

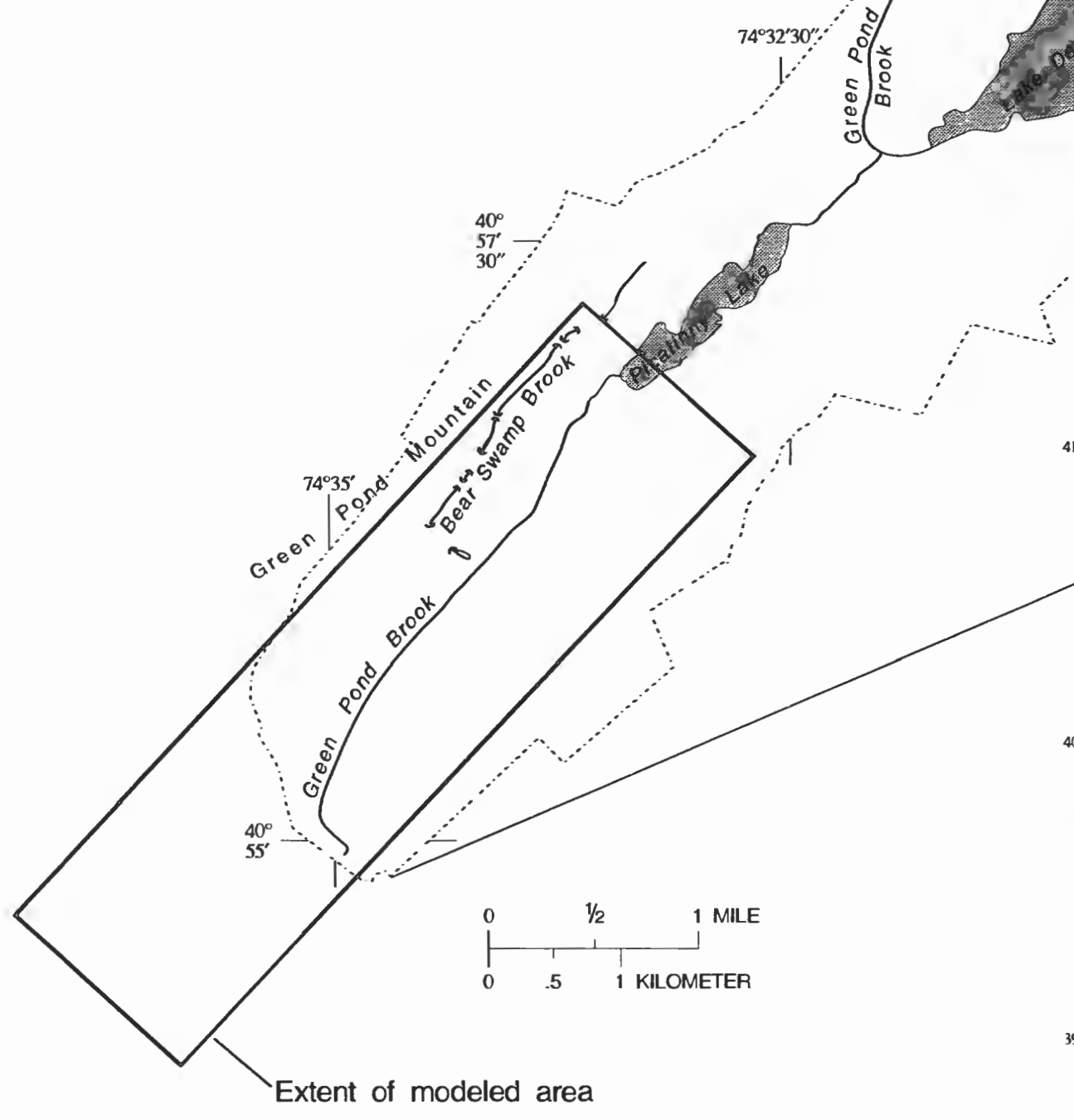




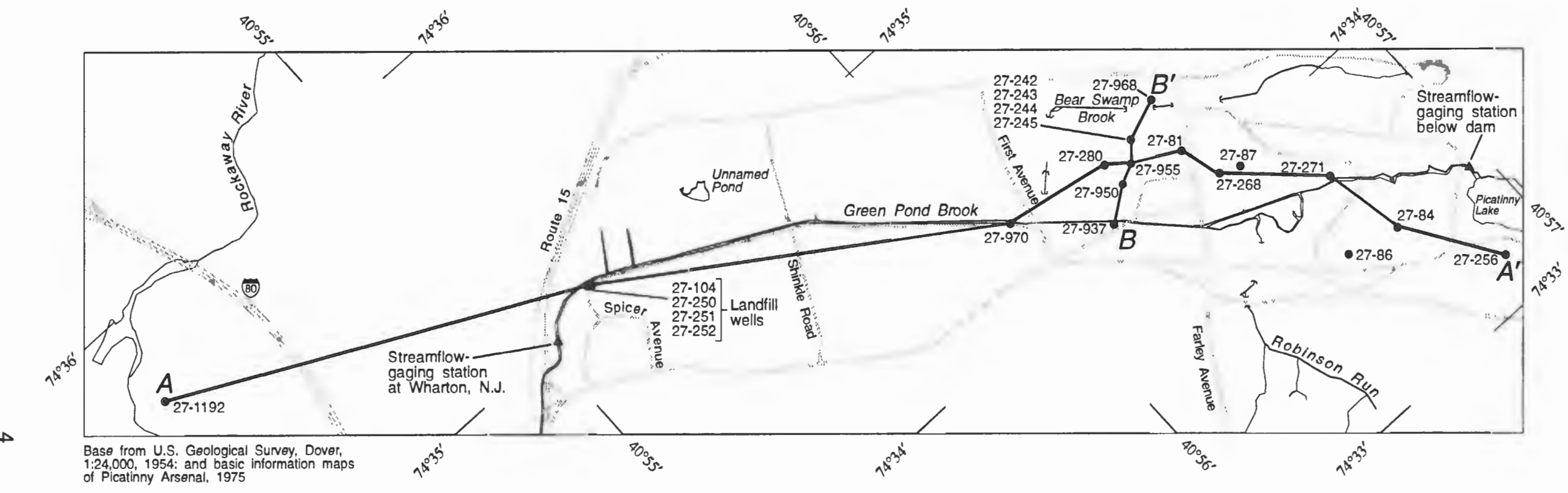

EXPLANATION
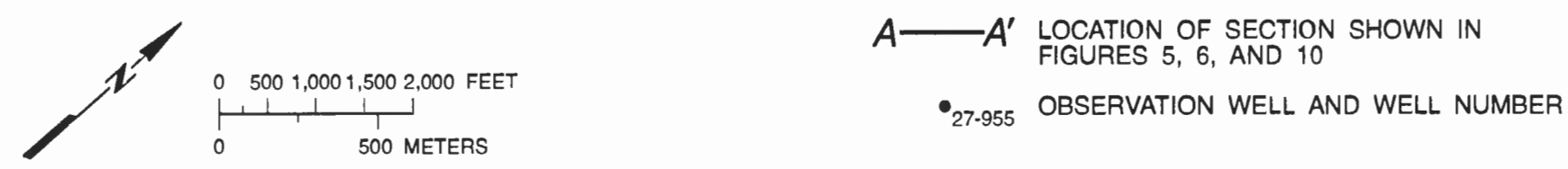

Figure 2. Area of the valley-wide ground-water-flow model and locations of hydrogeologic sections, selected observation wells, streamflow-gaging stations, and water-supply wells, Picatinny Arsenal and vicinity, New Jersey. 
Mountain on the west, Copperas Mountain on the northeast, and an unnamed mountain on the east (fig. 3). Green Pond and Copperas Mountains are rugged and have steep, rocky slopes; altitudes of their summits exceed 1,200 ft. The slopes on the eastern boundary are less rugged and less steep; maximum altitudes are about $1,100 \mathrm{ft}$. The valley is drained by Green Pond Brook.

\section{HYDROGEOLOGY}

The arsenal is in the central part of the New Jersey Highlands (fig. 1). The Highlands are a northeast-southwest-trending system composed of folded and faulted Precambrian to Devonian rocks that form a sequence of broad level highlands separated by long narrow valleys (Wolf, 1977). Stratigraphy and related lithology and geohydrologic units in the area are listed in table 1.

\section{Geology}

Precambrian gneiss, the oldest bedrock unit, is subdivided into three mineralogic rock types (Sims, 1958, pl. 1), as shown in table 1. The gneiss crops out along the eastern part of the arsenal and in part of the valley (fig. 4). The Hardyston Quartzite (Lower Cambrian) unconformably overlies the Precambrian Gneiss (Drake, 1969, p. 77). In New Jersey, the Hardyston Quartzite varies from a quartzite to a conglomerate and ranges in thickness from a few feet to about $200 \mathrm{ft}$ (Drake, 1969, p. 78). In the southeastern part of the arsenal, the Hardyston Quartzite underlies a small area of glacial deposits (fig. 4).

The Leithsville Formation is a Lower to Middle Cambrian unit that conformably overlies the Hardyston Quartzite (Drake, 1969, p. 79). In general, this formation consists of dolomite and some thin interbeds of quartzitic and dolomitic sandstone (Drake, 1969, p. $80)$.

The Green Pond Conglomerate of Silurian age is the youngest bedrock unit. Although the conglomerate crops out along Green Pond Mountain, the contact with the underlying Leithsville Formation is not exposed. The Leithsville is interpreted to be unconformably separated from the Green Pond Conglomerate by the steeply dipping Green Pond Fault (Sims, 1958, pl. 1). The Green Pond Conglomerate is a very coarse quartz conglomerate interbedded with and grading upward into quartzite and sandstone (Bayley and others, 1914, p. 33).

Continental ice sheets advanced across the study area at least twice during the Quaternary Period (Stanford, 1989). As a result, the bedrock surface is mantled by unconsolidated glacial deposits, predominantly till in the upland areas and stratified drift in the valleys. The various types of sediment deposited during the last glaciation are shown in figures 5 and 6 . In the study area, the distribution and characteristics of the stratified drift reflect the manner in which the area was deglaciated. Deglaciation began 


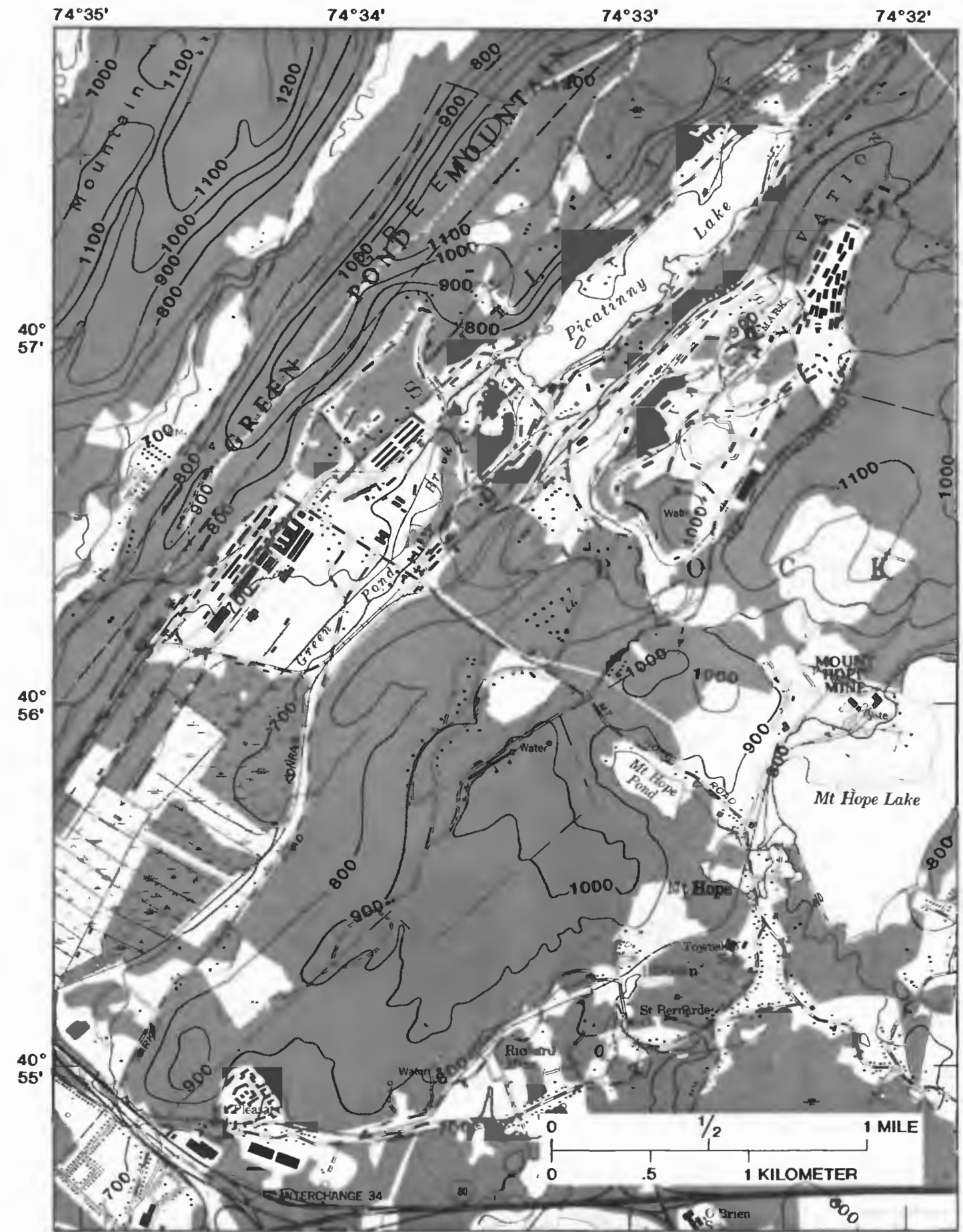

Base from U.S. Geological Survey.

1:24,000, quadrangle. Dover. 1954

\section{EXPLANATION}

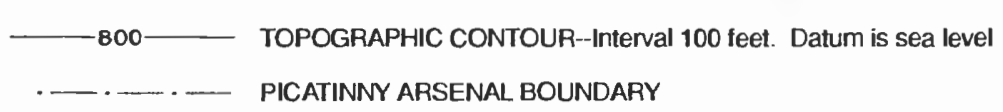

Figure 3. Physical features in the vicinity of Picatinny Arsenal, New Jersey (Modified from Sargent and others, 1990, fig. 2). 
Table 1. Stratigraphic and geohydrologic characteristics of geologic units at Picatinny Arsenal, New Jersey [Modified from Drake, 1969, table 20; Sims, 1958, pl. 1; Gill and Vecchioli, 1965, table 3]

\begin{tabular}{|c|c|c|c|c|c|c|}
\hline \multicolumn{3}{|c|}{ Time-stratigraphic unit } & \multirow{2}{*}{$\begin{array}{c}\text { Geologic unit } \\
\text { Formation or } \\
\text { lithnlogic unit } \\
\end{array}$} & \multirow{2}{*}{$\begin{array}{l}\text { Maximum } \\
\text { thickness } \\
\text { (in feet) }\end{array}$} & \multirow[b]{2}{*}{ Lithology } & \multirow[b]{2}{*}{ Geohydrologic characteristics } \\
\hline Era & System & Series & & & & \\
\hline \multirow{3}{*}{ 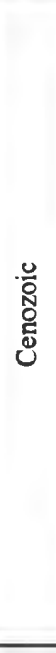 } & \multirow{3}{*}{ Quaternary } & Holocene & $\begin{array}{l}\text { Alluvium } \\
\text { Swamp deposits } \\
\text { (muck) }\end{array}$ & 10 & $\begin{array}{l}\text { Ranges from a sandy loam in the valley to } \\
\text { a stony gravel on hillsides } \\
\text { Black, brown, and gray organic material }\end{array}$ & $\begin{array}{l}\text { Too thin to be tapped } \\
\text { Permeability high along organic layers }\end{array}$ \\
\hline & & \multirow[t]{2}{*}{ Pleistocene } & Stratified drift & $200+$ & $\begin{array}{l}\text { Present in the form of glaciofluvial and } \\
\text { glaciolacustrine deposits. mostly sand- to } \\
\text { clay-size sediments; exhibits stratification } \\
\text { and in some cases rythmic laminations } \\
\text { (varves) }\end{array}$ & $\begin{array}{l}\text { Yield depends on degree of sorting and } \\
\text { grain size; the well-sorted and coarse- } \\
\text { grained deposits are productive aquifers } \\
\text { with yields up to } 2,200 \text { gallons per minute: } \\
\text { clay and silt deposits generally are unsuit- } \\
\text { able as aquifers }\end{array}$ \\
\hline & & & Unstratified drift & $100+$ & $\begin{array}{l}\text { Present in the form of ground, terminal, } \\
\text { and recessional moraine. Deposits gener- } \\
\text { ally are tightly packed and poorly sorted, } \\
\text { grain sizes ranging from boulders to clay } \\
\text { Unconfornity }\end{array}$ & $\begin{array}{l}\text { Yield depends on degree of sorting and } \\
\text { packing; generally low yields }\end{array}$ \\
\hline \multirow{3}{*}{$\begin{array}{l}\frac{\mathscr{O}}{8} \\
\frac{0}{0} \\
\frac{d}{0}\end{array}$} & Silurian & Upper & $\begin{array}{l}\text { Green Pond } \\
\text { Conglomerate }\end{array}$ & $1.500+$ & $\begin{array}{l}\text { Coarse quartz conglomerate interbedded } \\
\text { with and grading upward into quartzite and } \\
\text { sandstone, generally massive and red but } \\
\text { may contain white and green beds } \\
\text { Unconformity }\end{array}$ & $\begin{array}{l}\text { Generally yields small amount of water } \\
\text { from fractures and joints }\end{array}$ \\
\hline & \multirow[t]{2}{*}{ Cambran } & \multirow{2}{*}{$\begin{array}{l}\text { Middle } \\
\\
\text { Early } \\
\text { Lower }\end{array}$} & $\begin{array}{l}\text { Leithsville } \\
\text { Formation }\end{array}$ & $1.000+$ & $\begin{array}{l}\text { Predominantly a light- to medium-gray, } \\
\text { microcrystalline. locally stylolitic rock to a } \\
\text { fissile, siliceous to dolomitic micrite-tex- } \\
\text { ture rock; commonly highly weathered to a } \\
\text { medium-yellow, silty clay } \\
\text { Gradational }\end{array}$ & $\begin{array}{l}\text { Contains water-bearing fractures and solu- } \\
\text { tion cavities that generally have moderate } \\
\text { yields of up to } 380 \text { gallons per minute }\end{array}$ \\
\hline & & & Hardyston Quartzıte & 200 & $\begin{array}{l}\text { Orthoquartzite to conglomeratic; generally } \\
\text { well indurated }\end{array}$ & $\begin{array}{l}\text { Generally few fractures; yields small } \\
\text { amounts of water }\end{array}$ \\
\hline 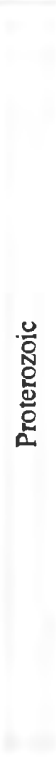 & & & $\begin{array}{l}\text { Hornblende } \\
\text { granite }\end{array}$ & & $\begin{array}{l}\text { Medium- to coarse-grained, predominantly } \\
\text { granitoid gneiss composed principally of } \\
\text { microperthite, quartz, and oligoclase: } \\
\text { includes local bodies of microantiperthite } \\
\text { granite and granite pegmatite; amphibolite } \\
\text { inclusions are common } \\
\text { Medium- to coarse-grained; predominantly } \\
\text { granitoid gneiss composed principally of } \\
\text { microperthite, quartz oligoclase, and horn- } \\
\text { blende; includes local bodie of biotite } \\
\text { granite, horneblended granite gneiss, gran- } \\
\text { odidrite, and granite pegmatite: amphibo- } \\
\text { lite inclusions are common } \\
\text { Medium- } 10 \text { coarse-grained gneiss of } \\
\text { widely varying composition; the predomi- } \\
\text { nant facies is composed of biotite. quartz, } \\
\text { and oligoclase: minor facies are character- } \\
\text { ized by abundant garnet and microperthite. } \\
\text { and locally by sillimanite and graphite }\end{array}$ & $\begin{array}{l}\text { All three lithologic units have similar } \\
\text { hydrologic characteristics; ground water } \\
\text { occurs in fractures and joints; yields gener- } \\
\text { ally are low, ranging from } 26 \text { to } 75 \text { gallons } \\
\text { per minute }\end{array}$ \\
\hline
\end{tabular}




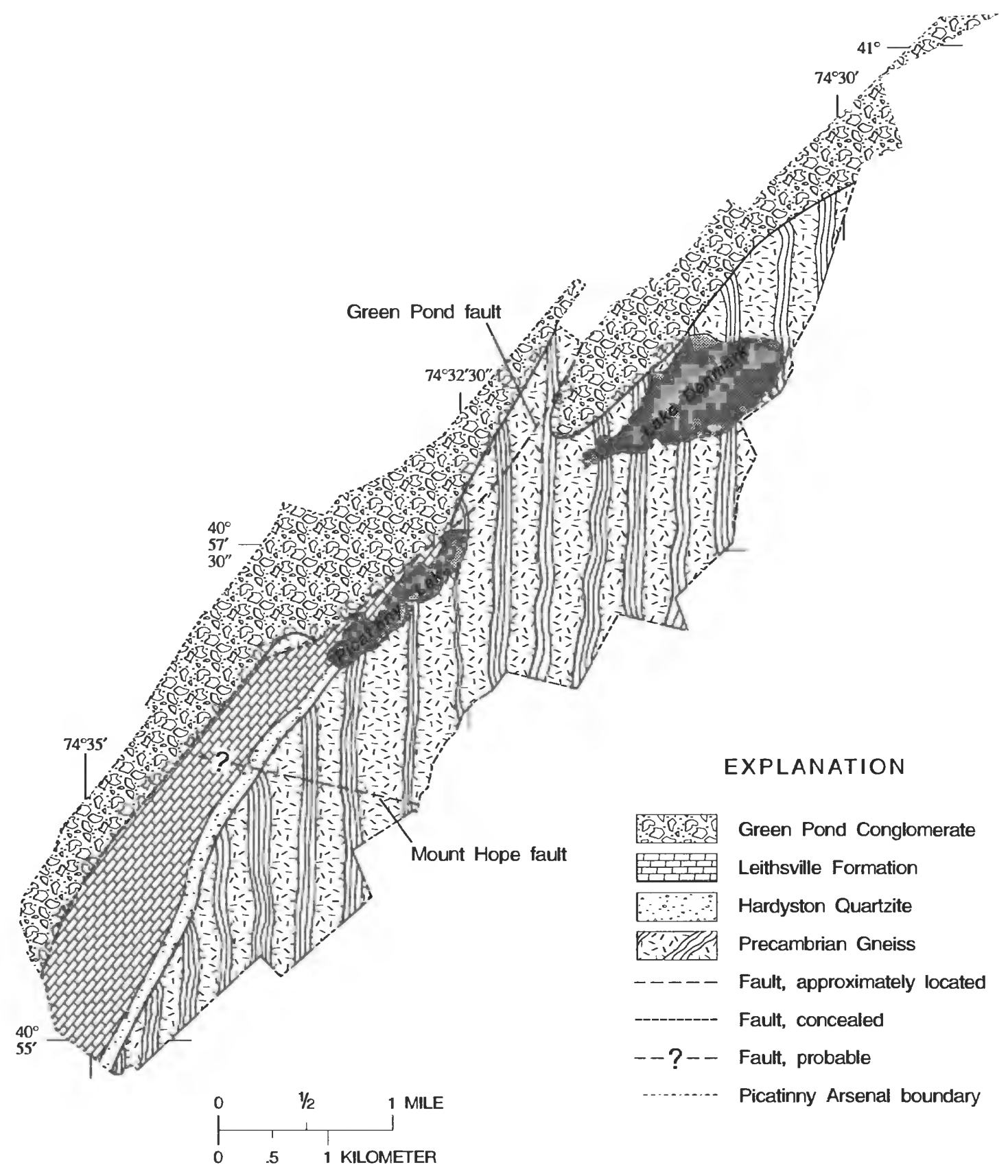

Base from U.S. Geological Survey 1:24,000 quadrangles

Geology moditied from Sims, 1958; and Bayley and others, 1914

Figure 4. Bedrock geology of Picatinny Arsenal, New Jersey (Modified from Lacombe and others, 1986, fig. 2). 


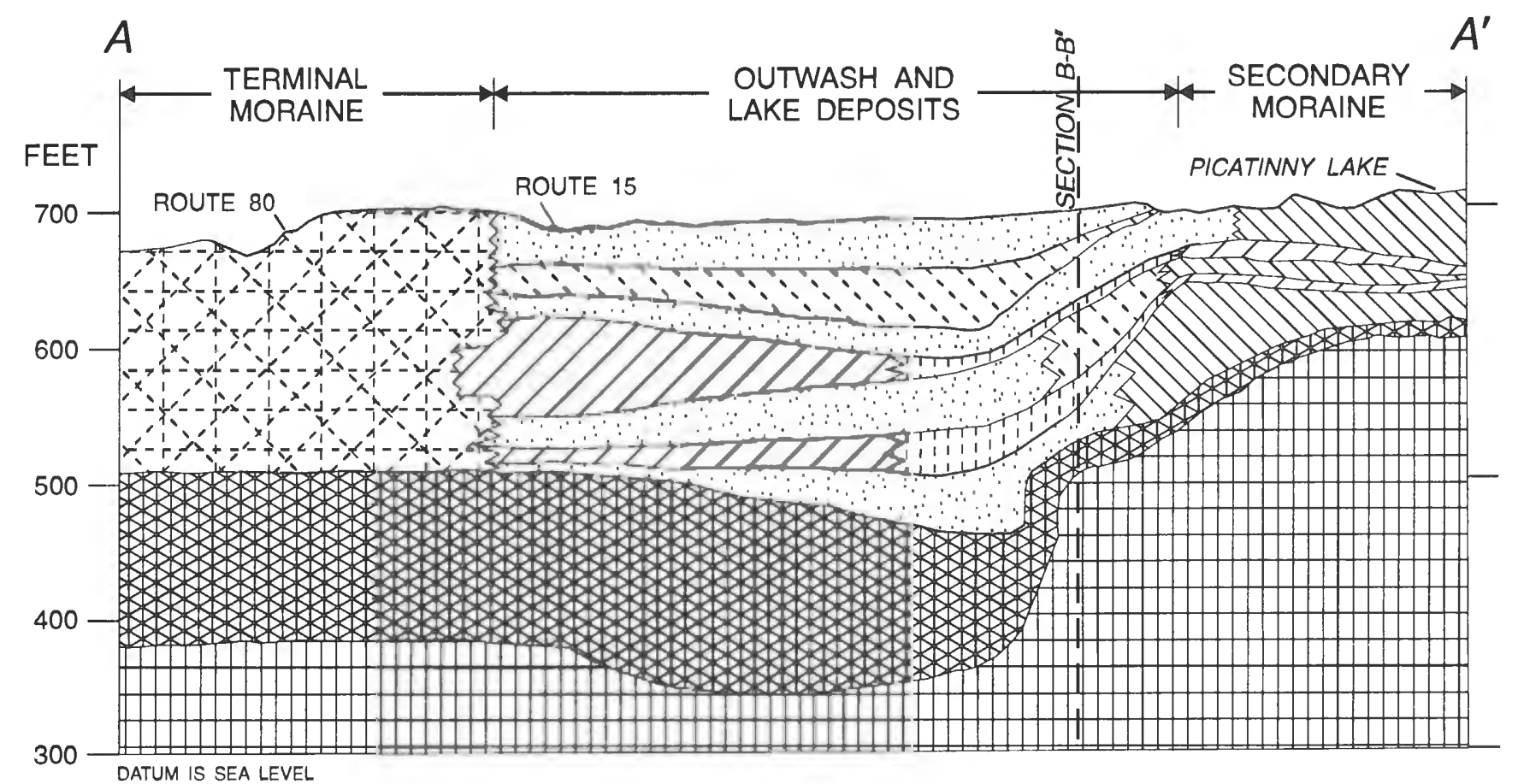

EXPLANATION

\begin{tabular}{|c|c|c|}
\hline SAND & AV & TILL, SAND, GRAVEL, AND BOULDERS \\
\hline SILT AND CLAY & & TILL, SAND, AND GRAVEL \\
\hline SAND AND SILT & O & WEATHERED BEDROCK (DOLOMITE) \\
\hline SILT AND SAND & 11 & BEDROCK (DOLOMITE) \\
\hline
\end{tabular}

2,000 FEET

0300600 METERS

Figure 5. Hydrogeologic section A-A' (down the valley), Picatinny Arsenal, New Jersey (location of section shown in fig. 2). 
FEET

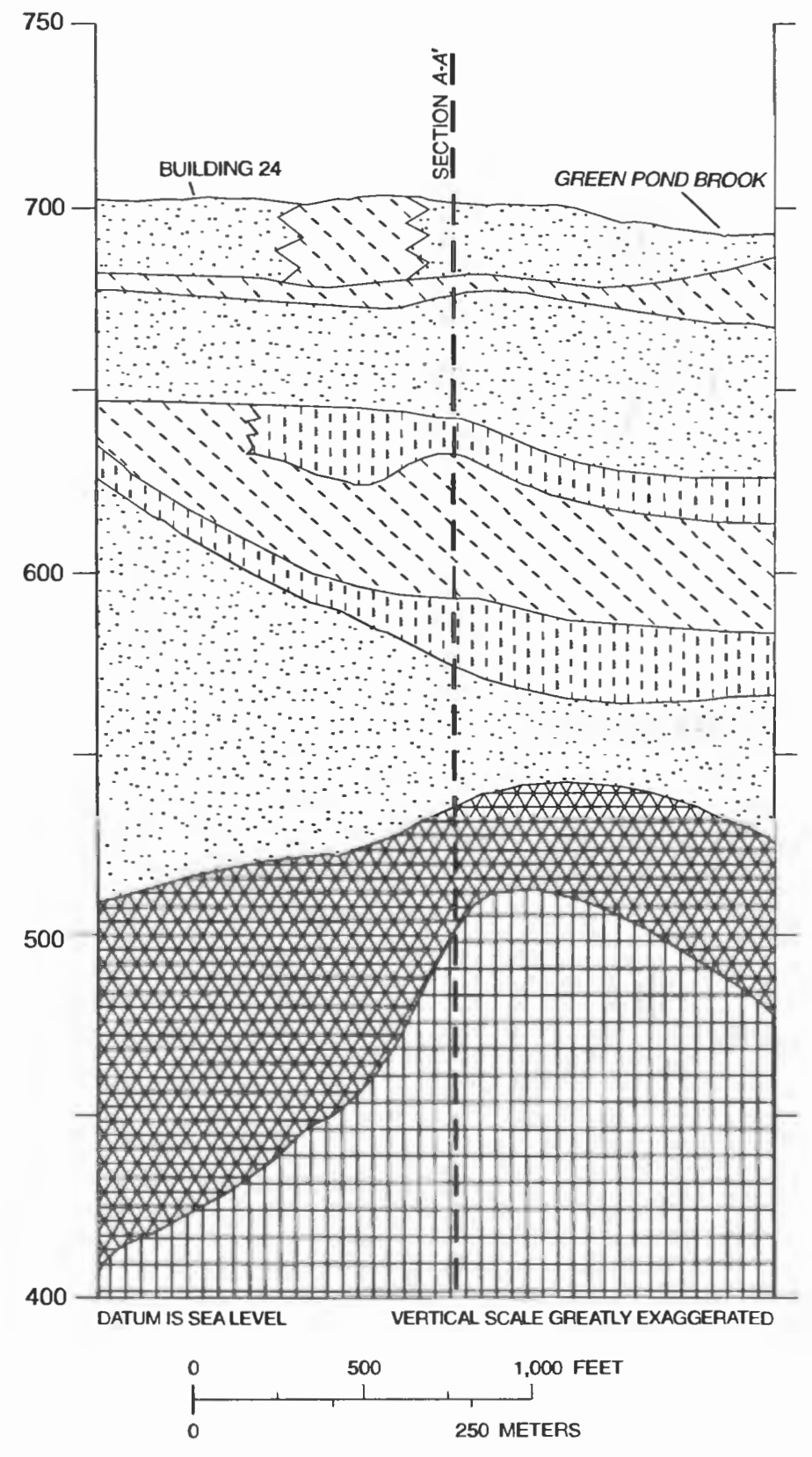

EXPLANATION

SAND
BEATHERED BEDROCK (DOLOMITE)
BEDROCK (DOLOMITE)
SIITI AND CLAY SILT

Figure 6. Hydrogeologic section B-B' (across the valley), Picatinny Arsenal, New Jersey (location of section shown in fig. 2). 
approximately 18,000 years ago and progressed in stages. The southernmost extent of glaciation is delineated by the terminal moraine at the southwestern boundary of the arsenal (fig. 1, inset map). The initial melting of ice north of the terminal moraine caused the formation of a temporary proglacial lake, Lake Picatinny. Glacial Lake Picatinny was dammed across the southern end by the moraine, and the glacier blocked northward drainage. The glacier receded to the southern end of the present-day Picatinny Lake, depositing a ridge of till. The lake drained to the southeast through a gap in a bedrock ridge at an altitude of about $700 \mathrm{ft}$ and was filled with a sequence of sediments: sublacustrine sand and gravel was overlain by lake-bottom and deltaic fine sand and silt and capped by deltaic sands and gravels. After deglaciation, deposits first of silt and clay and then peat formed in flood plains along Green Pond Brook and in large, ice-blocked depressions south of the terminal moraine (Stanford, 1989).

The hydrogeologic framework of the valley is depicted in two sections, one down the valley (section A-A'; fig. 5) and one across the valley (section B-B'; fig. 6). Till associated with terminal moraines is found at both ends of the valley (fig. 5). The sediments between the moraines are characterized by alternating lithologies indicating the varying stages of deposition from proglacial lake to outwash plain. The zone of weathered bedrock is thicker at the terminal moraine than under Picatinny Lake. Finer grained lithologies pinch out near the valley walls, leaving more homogeneous, coarser grained material throughout the section near the valley walls (fig. 6).

The altitude of the weathered bedrock in figure 5 is modified from that shown in Stanford (1989) on the basis of a seismic-refraction survey (P.J. Lacombe, U.S. Geological Survey, written commun., 1993). The thickness of the weathered zone of the bedrock either was determined from drillers' logs or was estimated for areas where data were unavailable. The thickness of the weathered zone ranges from $15 \mathrm{ft}$ at well 27-84 near Picatinny Lake to $130 \mathrm{ft}$ at well 27-250 near the southern boundary of the arsenal and Green Pond Brook. (Well locations are shown in figure 2.) The dolomite bedrock beneath the glacial sediments at Picatinny Arsenal weathers to a clay, which fills the fractures in the bedrock and impedes the flow of water; thus, the weathered zone of the bedrock is considered to be a confining unit.

\section{Conceptual Ground-Water-Flow System}

The principal source of ground water to Picatinny Arsenal and vicinity is local precipitation. The low permeability and the steep slopes of the adjacent mountains restrict the infiltration of precipitation, so that most of the precipitation that falls on the mountains flows overland to their base and infiltrates into the highly permeable glacial sediments near the valley walls. Effectively, all discharge from the ground-water system is to surface-water bodies, primarily the Rockaway River and Green Pond Brook. 
Figure 7 shows the generalized ground-water-flow paths in the bedrock and glacial sediments in cross-valley sections just north of First Street (fig. 2) and near the southern boundary of the arsenal. Near First Street (fig. 2), ground water generally flows into the glacial sediments at the base of the mountains; it then flows toward the center of the valley and from there flows upward beneath Green Pond Brook, where it discharges (fig. 7). This conceptual model is consistent with that described for sand and gravel aquifers in the glaciated northeastern United States by Lyford and Cohen (1988).

Ground-water flow at the arsenal's southern boundary differs from ground-water flow just north of First Street (fig. 7). Long-term water-level data (fig. 8) collected at a cluster of wells at the southern boundary landfill (27-104, 27-250, 27-251, and 27-252; fig. 2), near the valley axis show that water levels in well $27-250$ (open to the bedrock) are approximately $10 \mathrm{ft}$ lower than water levels in well 27-104 (screened in the water-table aquifer). These water-level data indicate that ground water near the southern boundary of the arsenal in the upper aquifer system is locally affected by seepage from Green Pond Brook, which is at an altitude of about $685 \mathrm{ft}$. At times, Green Pond Brook loses water to the underlying upper aquifer system; this flux of water keeps the water level in the upper aquifer system higher than the water level in the deeper aquifer system, which is hydraulically connected to the Rockaway River at an altitude of $660 \mathrm{ft}$.

\section{SIMULATION OF GROUND-WATER FLOW}

A three-dimensional finite-difference ground-water-flow model based on a computer code by McDonald and Harbaugh (1988) was used to simulate ground-water flow in the glacial sediments and the carbonate bedrock (Leithsville Formation) directly beneath the unconsolidated sediments at Picatinny Arsenal and vicinity. The modeled area was extended beyond the southern boundary of the arsenal to the Rockaway River (fig. 2), a major discharge area in the valley.

\section{Model Design}

A finite-difference grid consisting of 36 rows and 95 columns was used to discretize the glacial sediments and bedrock (fig. 9). The grid spacing ranges from 70 to $800 \mathrm{ft}$, and cell sizes range from 5,600 to $320,000 \mathrm{ft}^{2}$. The largest cell in the grid for Picatinny Arsenal represents an area near Spicer Road that measures $400 \mathrm{ft}$ on each side. The grid orientation is approximately parallel to the general flow direction of Green Pond Brook. The grid was designed to allow for an evaluation of alternative water-supply sources, an analysis of advective contaminant transport by use of flow-path tracking methods, and the simulation of two aquifer tests done at the arsenal. 
A

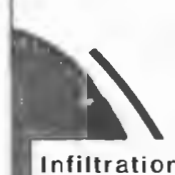

upland runof

th

precipitation
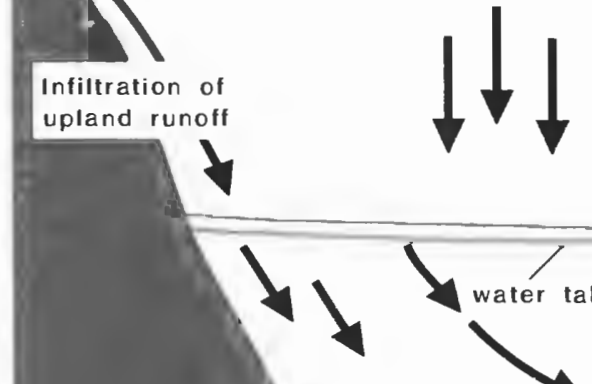

Green Pond Brook
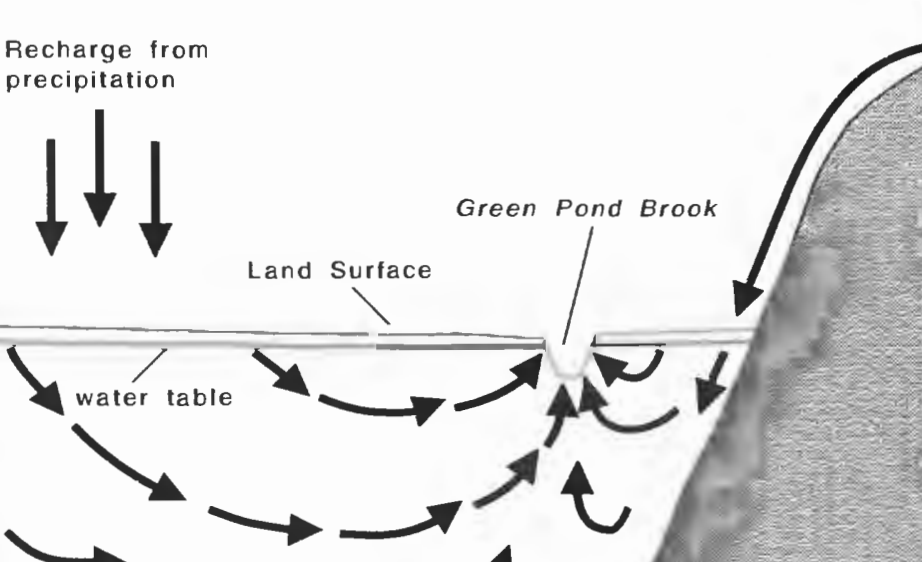

Glacial Sediments

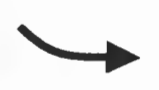

$\sqrt{7}$

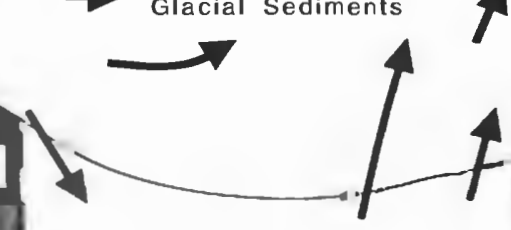

Leithsville Formation

(dolomite)

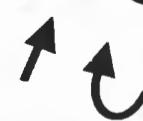

Proterozoic Gneiss

Green Pond Conglomerate

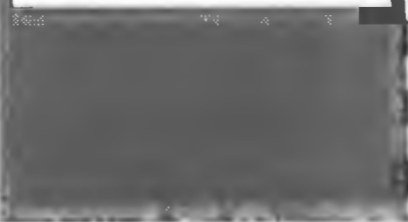

NOT TO SCALE

EXPLANATION

4 General direction of ground-water flow
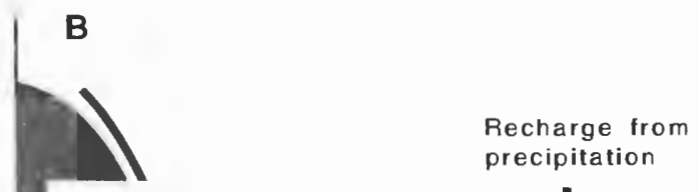

Infiltration of

upland runoff
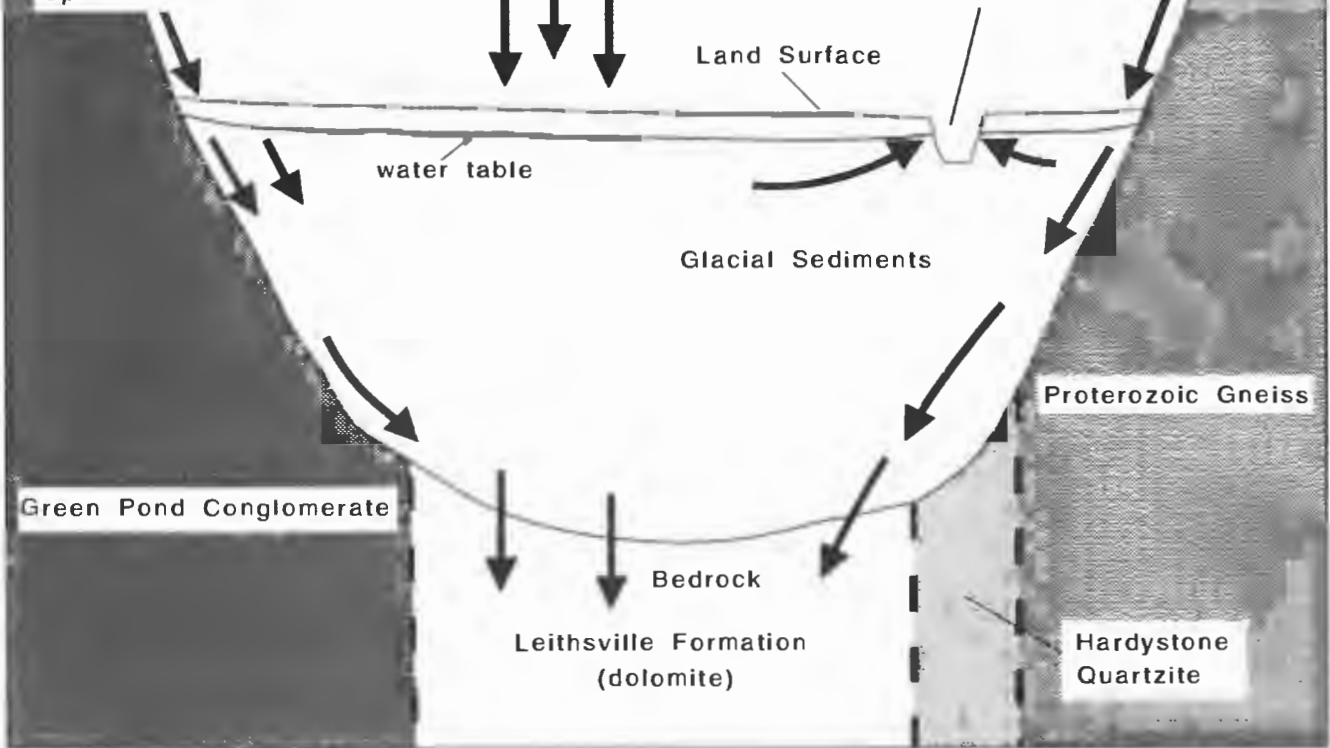

precipitation

NOT TO SCALE

Figure 7. General hydrogeologic sections through the ground-water-flow system at Picatinny Arsenal, New Jersey (A) north of First Street and (B) at the southern boundary of the arsenal. 


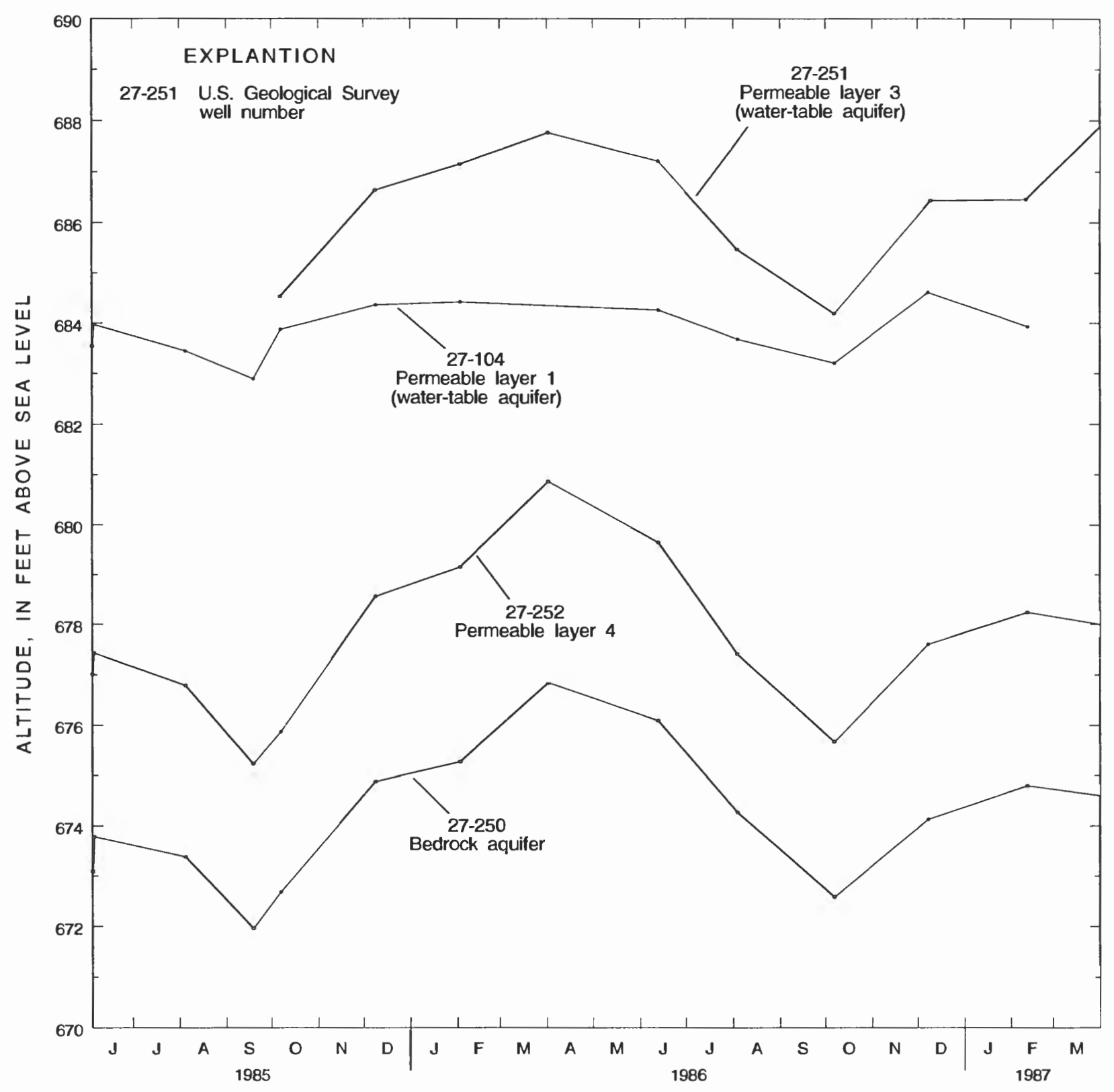

Figure 8. Water-level hydrograph of wells at the landfill at Picatinny Arsenal, New Jersey, June 1985 through March 1987 (well locations shown in fig. 2). 


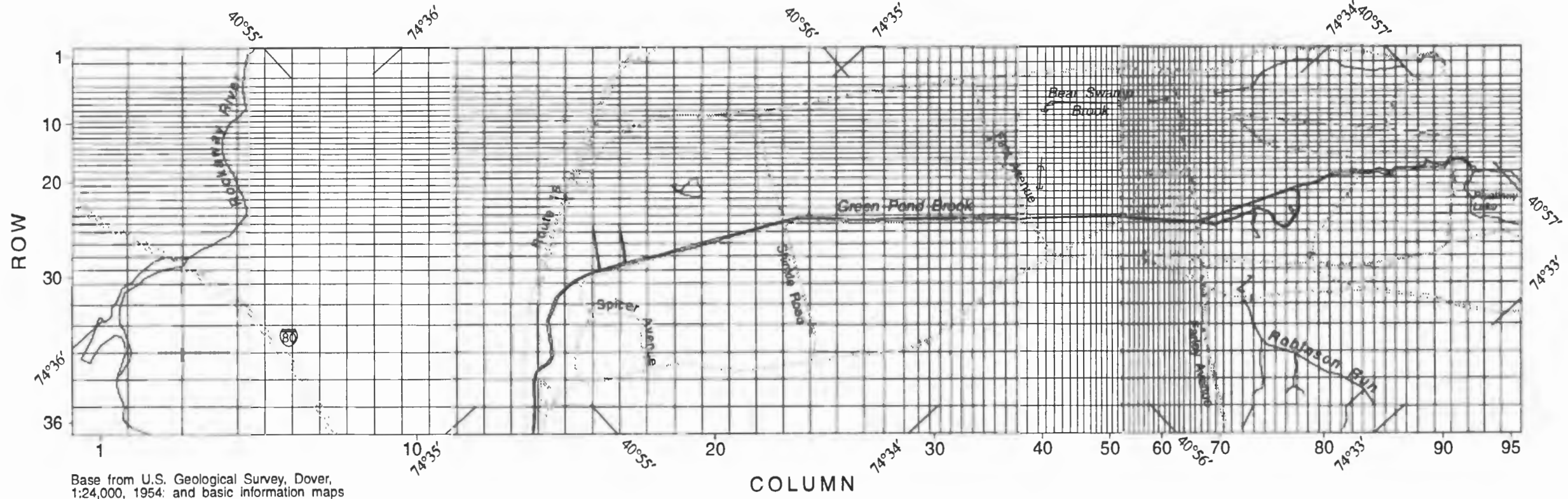

Base from U.S. Geological Survey, Dover,
1:24,000, 1954 : and basic intormation maps
of Picatinny Arsenal, 1975

o $5001,0001,5002,000$ FEET

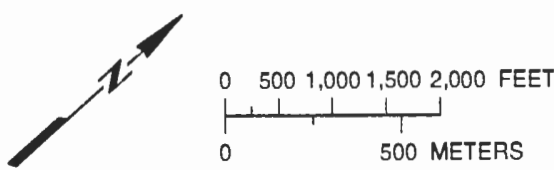

Figure 9. Finite-difference grid used to simulate ground-water flow at Picatinny Arsenal and vicinity, New Jersey. 


\section{Discrete Framework}

The discrete model representation of the aquifers and confining units at Picatinny Arsenal and vicinity (fig. 10) were delineated from the analysis of gamma-ray logs, particle-size data, and lithologic logs of wells at Picatinny Arsenal. The wells and the types of data used to define the surface altitude of these units are listed in table 2. Much of the data used is published in reports by Harte and others (1986), Sargent and others (1990), and Lacombe and others (1986). Some data were collected more recently and are on file at the U.S. Geological Survey office, West Trenton, N.J. The layering scheme of the model enabled simulation of horizontal flow within units having sufficient hydraulic conductivity and only vertical flow through confining layers. Some transmissive zones are represented by multiple layers to permit modeling of variations in hydraulic conductivity.

The bedrock and glacial sediments at Picatinny Arsenal were divided into a sequence of six permeable layers represented as aquifers and three low-permeability layers represented as confining units. Grain size and the general hydraulic properties of the sediments were the basis for this characterization. Virtually impermeable confining units, such as thick clay units, do not appear to be present at Picatinny Arsenal; however, units containing clay and silt that significantly impede the flow of ground water are present. A layer was designated as a confining unit if that layer's ability to transmit water was significantly lower than that of the aquifer units.

A relation between the size of the peak on the gamma-ray log and the type of sediment in a well was determined by a review of gamma-ray and lithologic logs and, if available, particle-size data. If only gamma-ray logs were available, permeable and lowpermeability layers of the glacial sediments were identified by use of the gamma-ray logs and the relation between peak size and sediment type. Layers containing fine sands and silts and sand layers consisting of 50 percent or more silt or clay were designated as lowpermeability layers; layers containing medium and coarse sands and (or) boulders were designated as permeable layers. Thickness maps for the permeable and low-permeability layers are shown in figures 11 through 18. The combined thickness of the glacial sediments ranges from $90 \mathrm{ft}$ at well 27-84 near Picatinny Lake to $185 \mathrm{ft}$ at well 27-250 near the southern boundary of the arsenal (fig. 10).

The sequence of permeable and low-permeability layers within the arsenal appears to be absent from the glacial sediments southwest of Route 15. Lithologic logs of wells in this area do not indicate any continuous layers of fine sediments within $90 \mathrm{ft}$ of land surface. Southwest of Route 15, a large mass of sediments was deposited at the terminal moraine by the last glacier. A glacial lake formed northeast of Route 15 and southwest of Picatinny Lake during the last glaciation, and a sequence of layers was deposited during that long period of time. For the purposes of this investigation, the permeable layers underlying Picatinny Arsenal were continued beyond the arsenal boundary to the Rockaway River (fig. 10); therefore, the moraine deposits in this area are represented as 


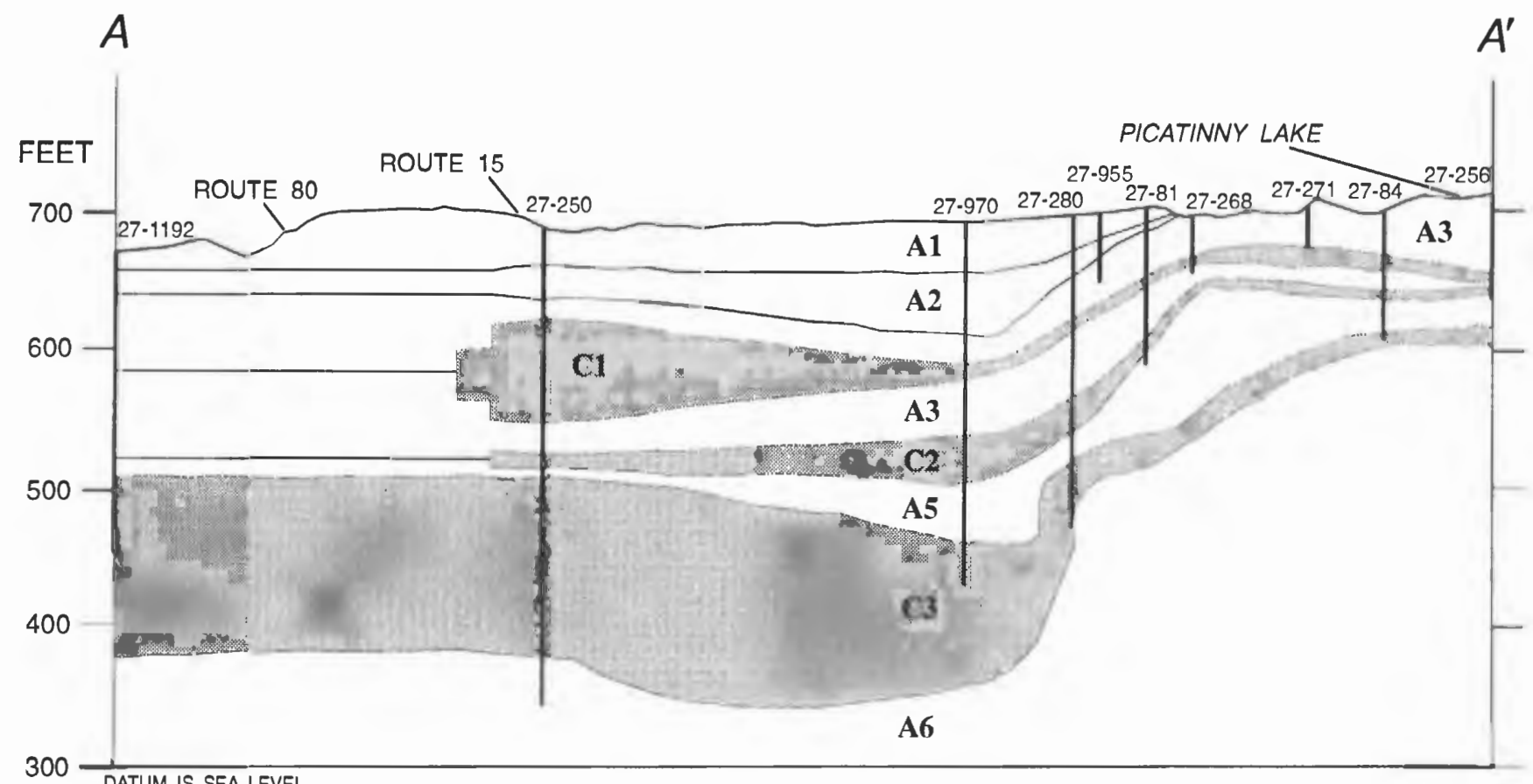

EXPLANATION

$\begin{array}{lll}0 & 1,000 & 2,000 \\ \end{array}$

300 TO0 METERS

A1 MODEL AQUIFER LAYER--Letter and number correspond tolayer designation used in model

C1. MODEL CONFINING UNIT--Letter and number correspond
to layer designation used in model

27-271 LOCATION OF WELL AND WELL NUMBER

(1)

Figure 10. Section A-A' (down the valley) showing model layers used in the valley-wide ground-waterflow model, Picatinny Arsenal, New Jersey (location of section shown in fig. 2). 
Table 2. Wells and types of data used to delineate the hydrologic units at Picatinny Arsenal and vicinity, New Jersey

[x, data available; --, no data available]

\begin{tabular}{|c|c|c|c|c|c|}
\hline \multirow[b]{2}{*}{$\begin{array}{c}\text { Well } \\
\text { number }\end{array}$} & \multirow[b]{2}{*}{$\begin{array}{l}\text { Local } \\
\text { name }\end{array}$} & \multicolumn{3}{|c|}{ Type of data } & \multirow{2}{*}{$\begin{array}{c}\text { Depth } \\
\text { of well } \\
\text { (feet below land } \\
\text { surface) }\end{array}$} \\
\hline & & $\begin{array}{c}\text { Lithologic } \\
\log \end{array}$ & $\begin{array}{c}\text { Gamma-ray } \\
\text { log } \\
\end{array}$ & $\begin{array}{c}\text { Particle } \\
\text { size }\end{array}$ & \\
\hline $27-81$ & 129 & $\mathbf{x}$ & .- & -- & 113 \\
\hline $27-82$ & 130 & $x$ & -- & -- & 117 \\
\hline $27-83$ & 302D & $\mathbf{x}$ & - & -- & 404 \\
\hline $27-84$ & $430 \mathrm{~A}$ & $\mathbf{x}$ & - & -- & 190 \\
\hline $27-85$ & 530 & $\mathbf{x}$ & -- & - & 109 \\
\hline $27-86$ & 410 & $\mathrm{x}$ & -- & - & 92.5 \\
\hline $27-242$ & Caf-1 & $\mathrm{x}$ & $\mathbf{x}$ & $\mathrm{x}$ & 268 \\
\hline $27-246$ & Bld 65-I & $\mathbf{x}$ & $\mathbf{x}$ & $\mathbf{x}$ & 287 \\
\hline $27-250$ & LF-1 & $\mathrm{x}$ & $\mathbf{x}$ & $\mathbf{x}$ & 345 \\
\hline $27-256$ & $507 \mathrm{~B}$ & $\mathbf{x}$ & $\mathbf{x}$ & & 80 \\
\hline $27-268$ & 151 & $\mathbf{x}$ & $\mathbf{x}$ & $\mathbf{x}$ & $1_{40}$ \\
\hline $27-280$ & H-Deep & $\mathbf{x}$ & $\mathbf{x}$ & $x$ & 223 \\
\hline $27-276$ & 178 & $\mathrm{x}$ & $\mathbf{x}$ & $\mathrm{x}$ & 74 \\
\hline $27-277$ & 176 deep & $\mathbf{x}$ & $x$ & $\mathbf{x}$ & 305 \\
\hline $27-937$ & 41-1 & $\mathbf{x}$ & $\mathbf{x}$ & -- & 44.6 \\
\hline $27-950$ & $112-7$ & $\mathbf{x}$ & $\mathbf{x}$ & -. & 51.1 \\
\hline $27-955$ & $92-3$ & $\mathbf{x}$ & $x$ & -- & 55.2 \\
\hline $27-963$ & $31-2 A$ & & & & 30.9 \\
\hline $27-968$ & $10-3 A$ & $\mathbf{x}$ & $\mathbf{x}$ & -- & 264 \\
\hline $27-970$ & $39-1$ & $\mathbf{x}$ & $x$ & -- & ${ }^{\prime} 258$ \\
\hline $27-973$ & $95-2$ & $\mathrm{x}$ & $\mathrm{x}$ & -- & 200 \\
\hline $27-1130$ & SB2-1A & $\mathbf{x}$ & $\mathbf{x}$ & - & 168 \\
\hline $27-1132$ & SB3-1A & $\mathbf{x}$ & $\mathrm{x}$ & - & 360 \\
\hline $27-1134$ & SB3-2 & $\mathbf{x}$ & $\mathbf{x}$ & -- & 180 \\
\hline $17-1192$ & $\begin{array}{l}\text { Morris Maint } \\
\text { Yd 22-Obs }\end{array}$ & $\mathrm{x}$ & $\mathbf{x}$ & -- & ${ }^{1} 191$ \\
\hline $27-1248$ & $1179-1$ & $\mathrm{x}$ & $\mathrm{x}$ & -- & 50.2 \\
\hline $27-1252$ & $1179-4 \mathrm{~B}$ & $\mathbf{x}$ & $\mathrm{x}$ & -- & 151 \\
\hline $27-1263$ & $1180-1$ & $\mathbf{x}$ & $\mathbf{x}$ & -- & 61.3 \\
\hline $27-1265$ & $1180-2 A$ & $\mathbf{x}$ & $\mathrm{x}$ & -- & 134 \\
\hline $27-1594$ & $\begin{array}{l}\text { Highland of } \\
\text { Morris-1 }\end{array}$ & $\mathbf{x}$ & -- & -- & 80 \\
\hline
\end{tabular}

${ }^{1}$ Depth to which well was drilled 


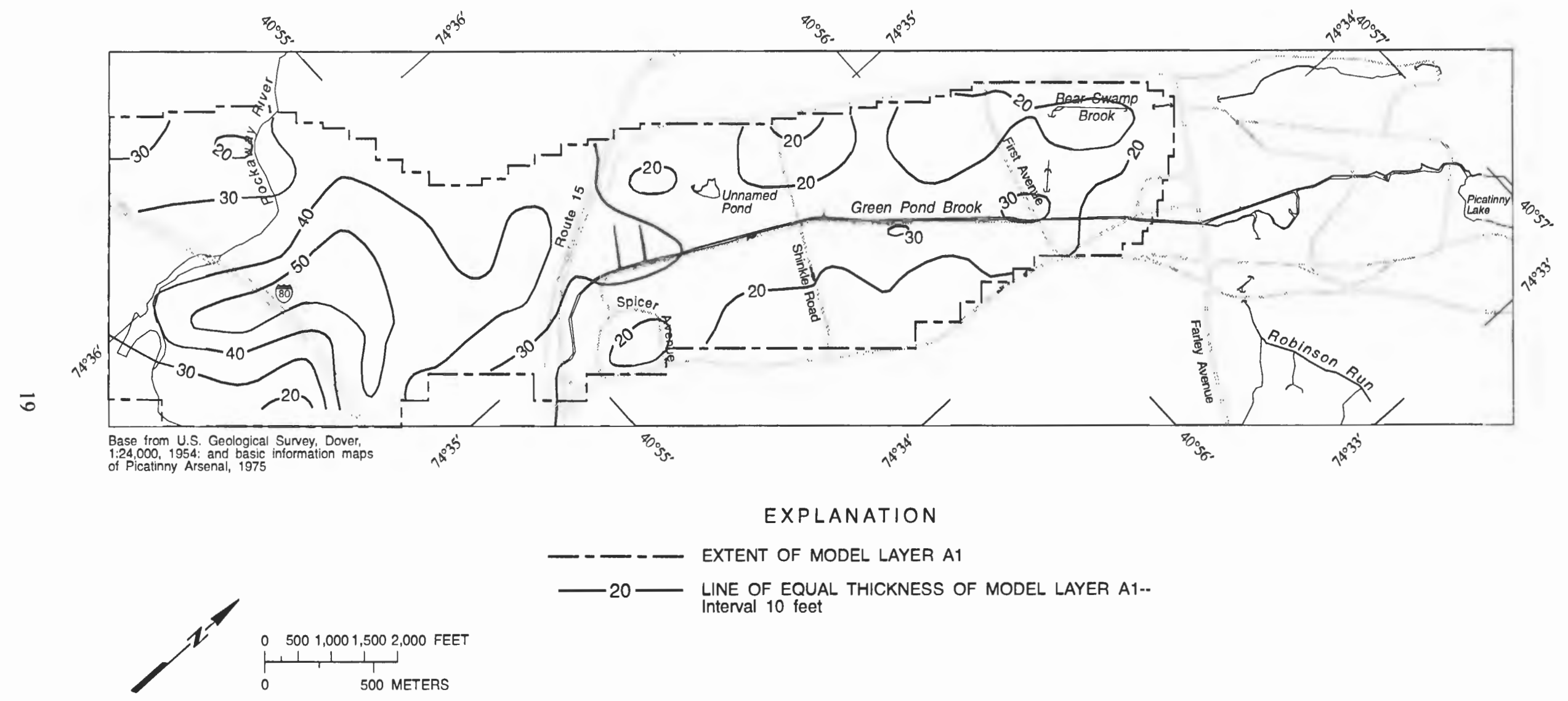

Figure 11. Thickness of model layer A1, Picatinny Arsenal and vicinity, New Jersey. 


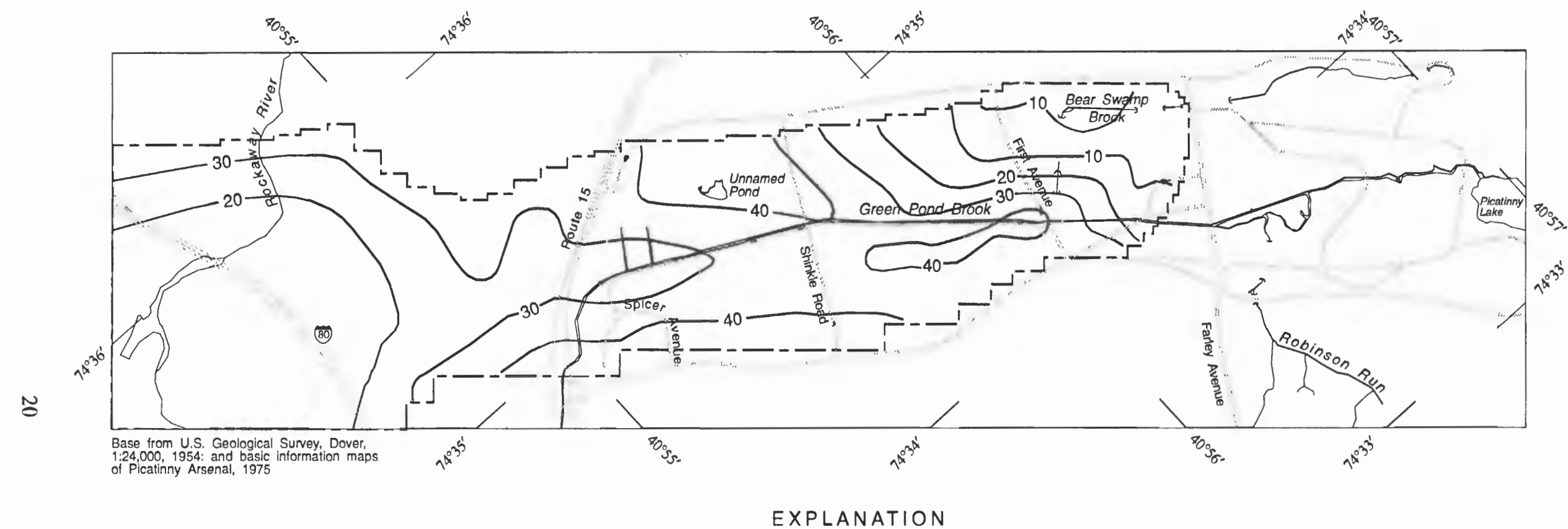

- - - - EXTENT OF MODEL LAYER A2

- $20-$ LINE OF EQUAL THICKNESS OF MODEL LAYER A2--

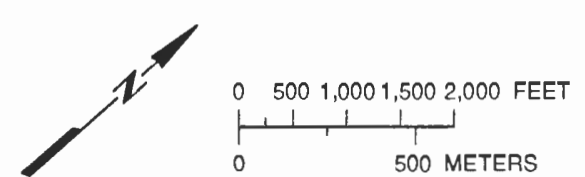

Figure 12. Thickness of model layer A2, Picatinny Arsenal and vicinity, New Jersey. 


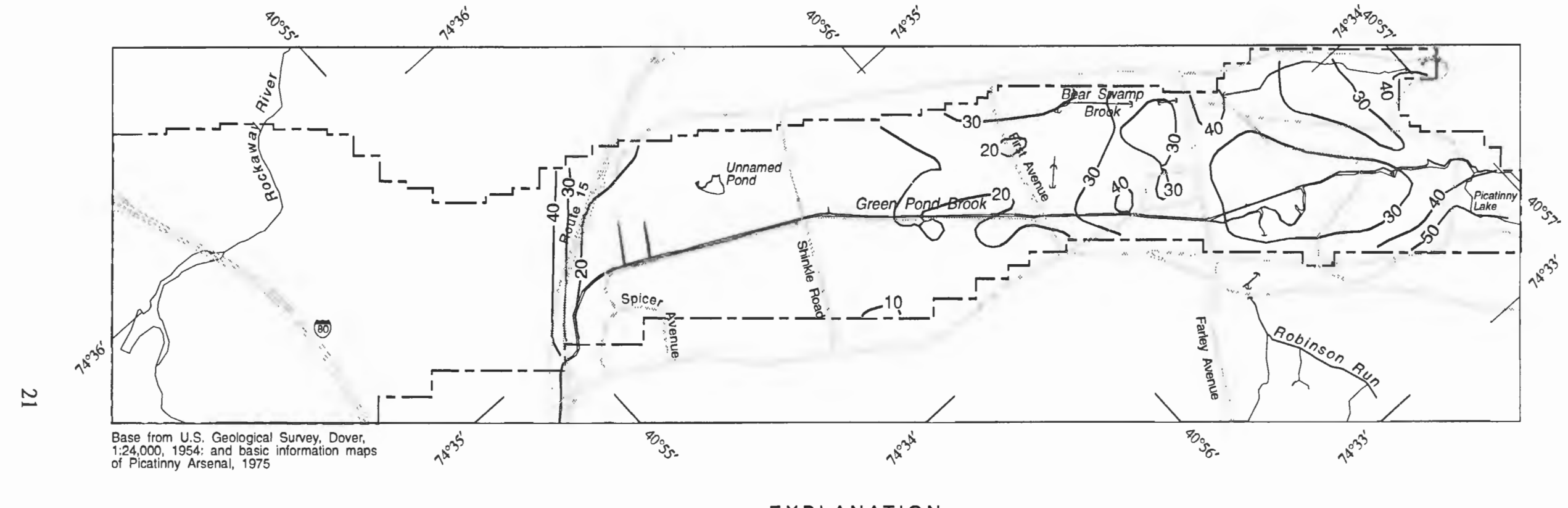

\section{EXPLANATION}

- - - - EXTENT OF MODEL LAYER A3

$-20-$ LINE OF EQUAL THICKNESS OF MODEL LAYER A3-Interval 10 feet

$0 \quad 5001,0001,5002,000$ FEET

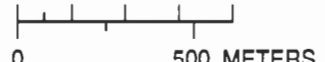

Figure 13. Thickness of model layer A3, Picatinny Arsenal and vicinity, New Jersey. 

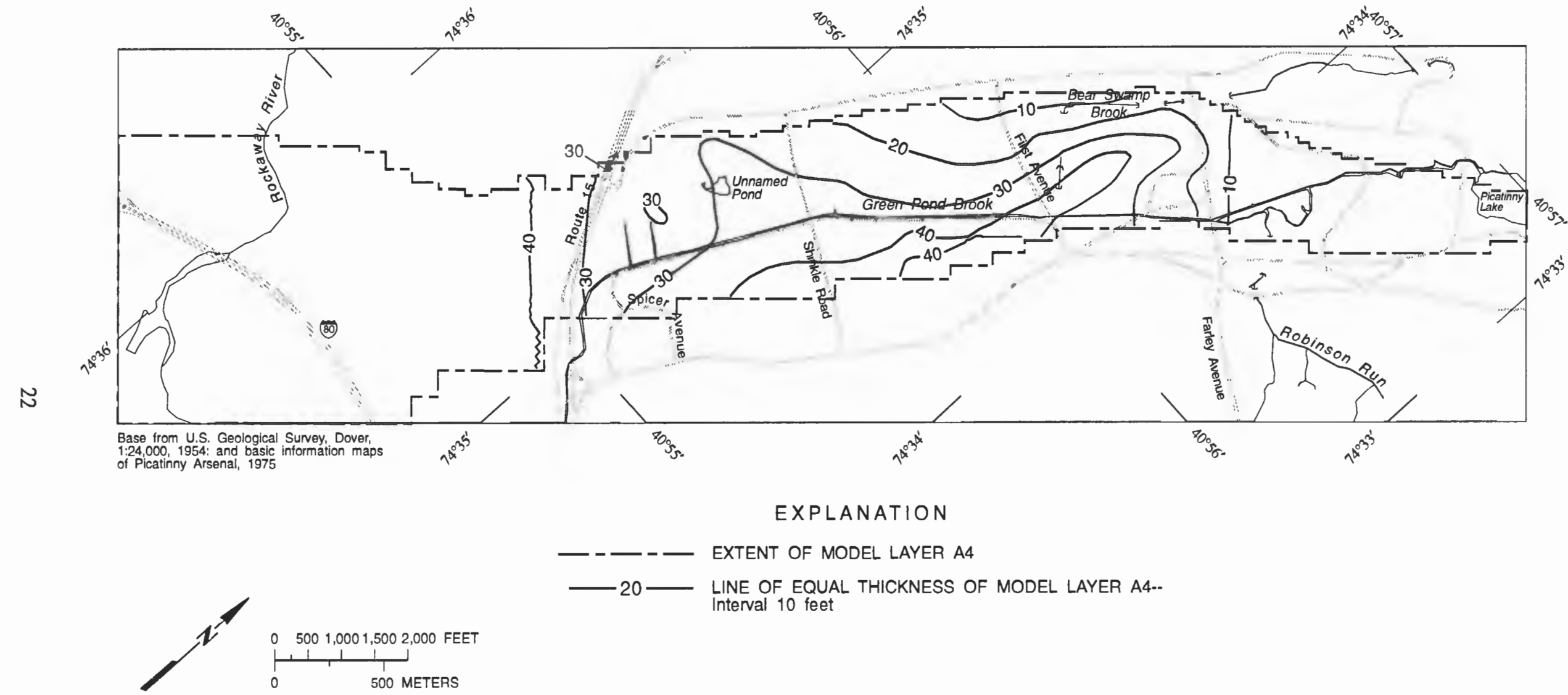

Figure 14. Thickness of model layer A4, Picatinny Arsenal and vicinity, New Jersey. 


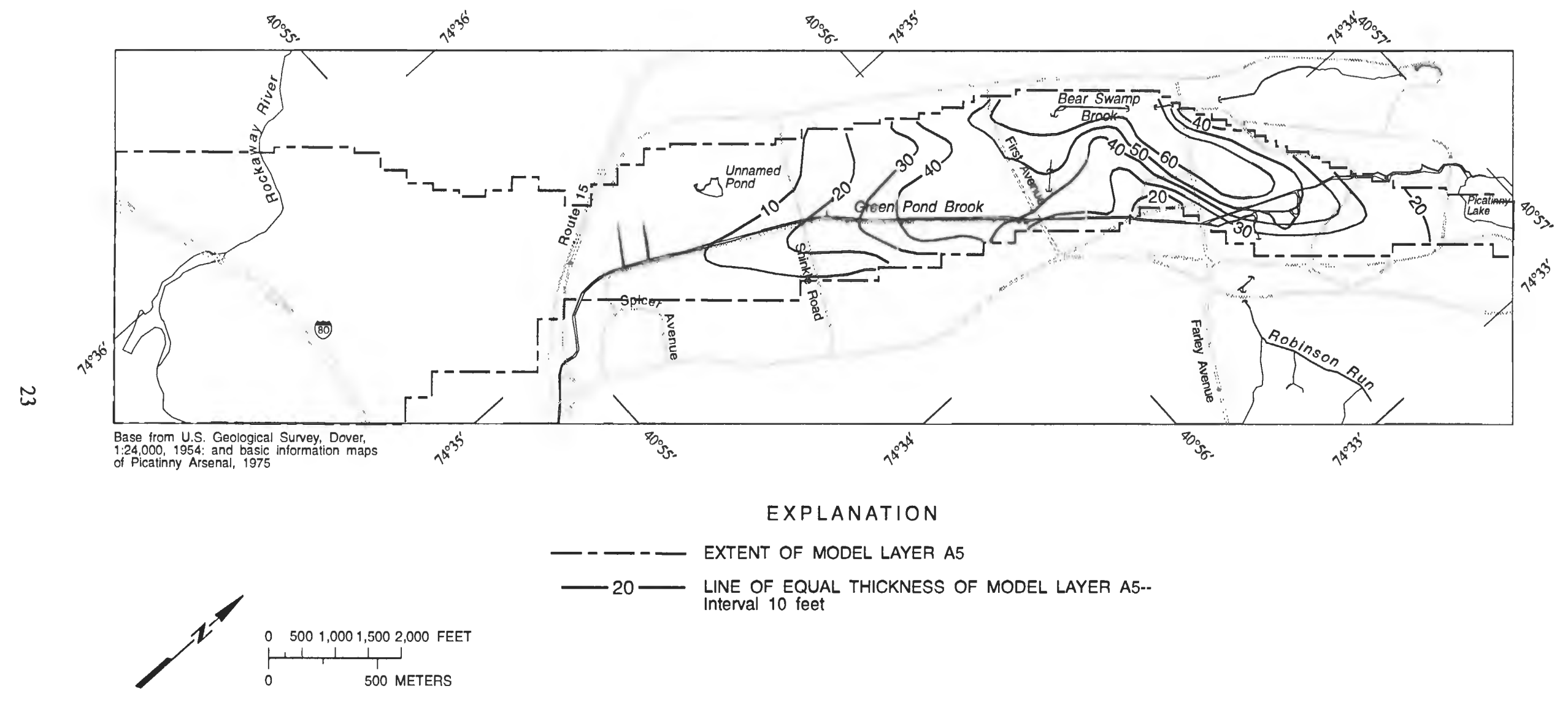

Figure 15. Thickness of model layer A5, Picatinny Arsenal and vicinity, New Jersey. 


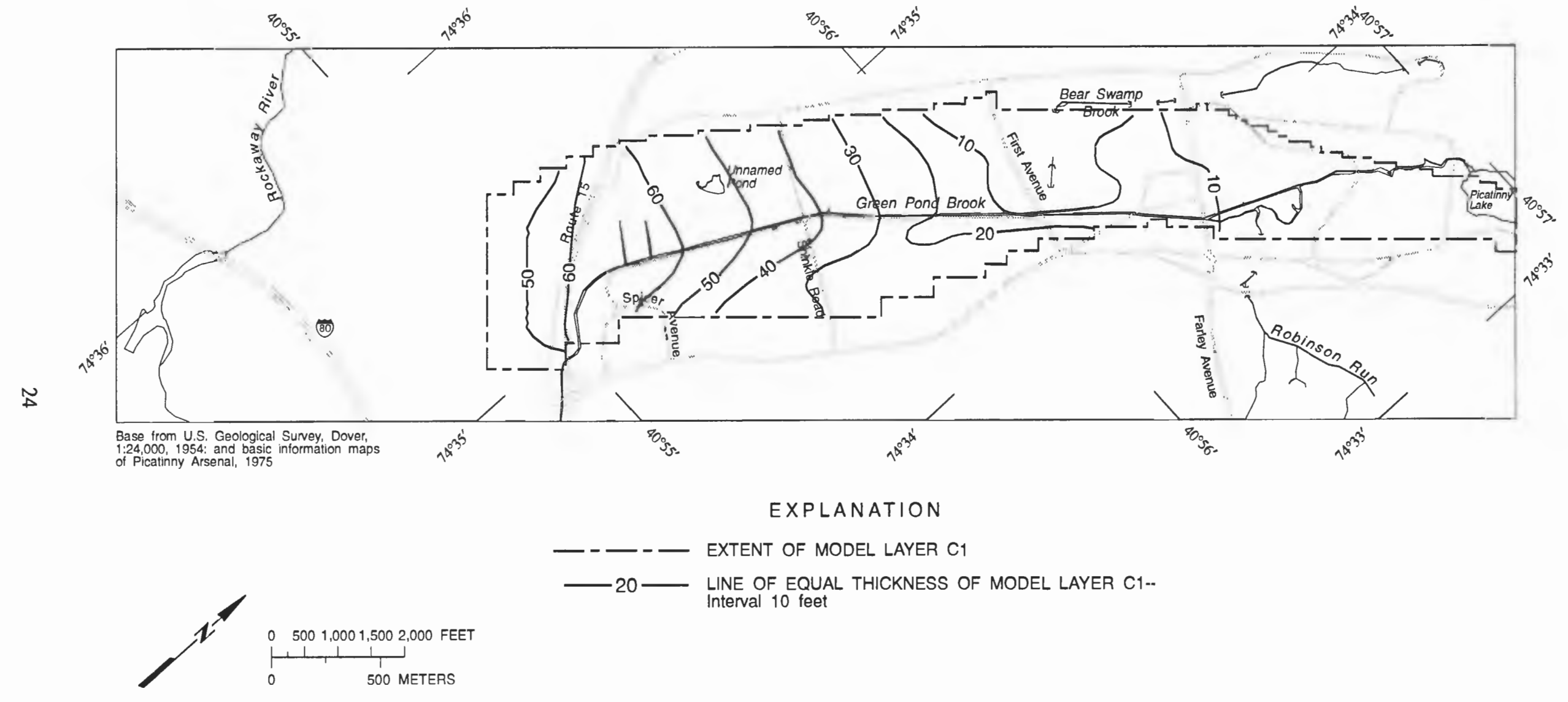

Figure 16. Thickness of model layer C1, Picatinny Arsenal and vicinity, New Jersey. 


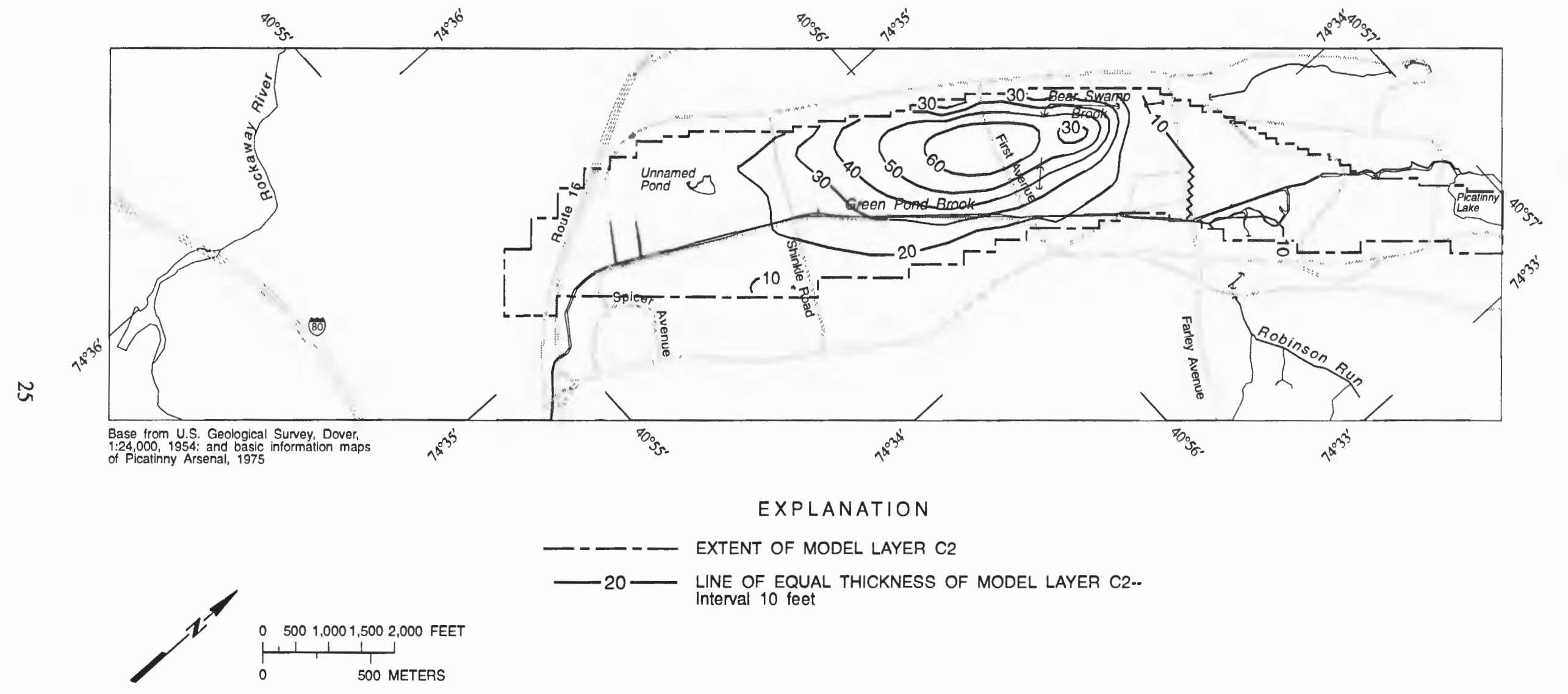

Figure 17. Thickness of model layer C2, Picatinny Arsenal and vicinity, New Jersey. 


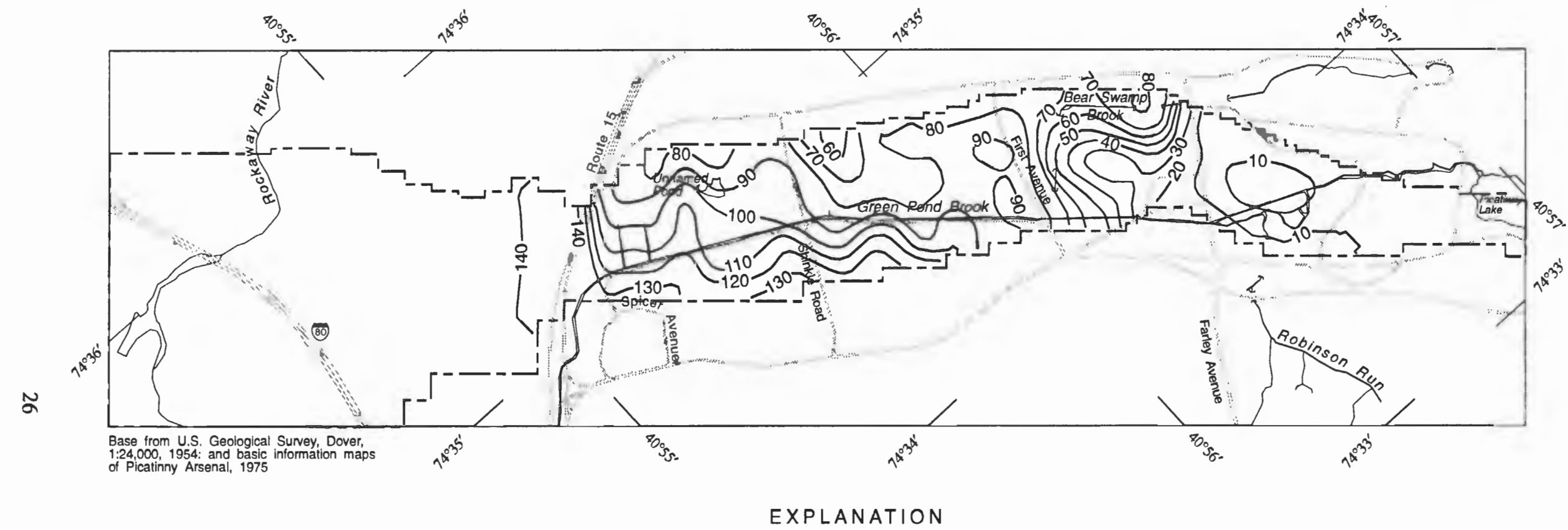

- - - - EXTENT OF MODEL LAYER C3

$-20-$ LINE OF EQUAL THICKNESS OF MODEL LAYER C3.Interval 10 feet

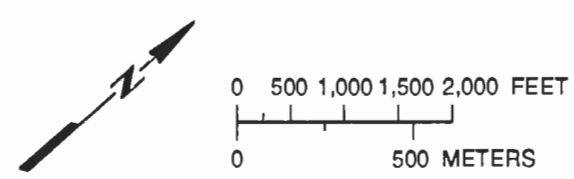

Figure 18. Thickness of model layer C3, Picatinny Arsenal and vicinity, New Jersey. 
five separate layers with similar hydraulic properties. This representation enables evaluation of vertical gradients in this thick sequence of unconsolidated sediments and of the interaction of flow between these sediments and the individual aquifers northwest of Route 15.

Model layer A1 was simulated as a water-table aquifer. Model layer A3 was simulated as a water-table aquifer northeast of Farley Avenue, where it is the uppermost layer, and as a confined aquifer southwest of Farley Avenue, where it is the third layer from the top (fig. 2 and 10). Layers A2, A4, A5, and A6 (the bedrock aquifer) were represented as confined-aquifer layers. The confined aquifers were represented so that they could be converted to unconfined aquifers if water levels were drawn down below the aquifer's upper surfaces. Model layers A1, A2, and A3 represent the water-table aquifer within the arsenal boundaries.

\section{Boundary Conditions}

Most of the model boundaries coincide with the natural hydrologic boundaries of this ground-water system. Figures 19 and 20 show the model boundaries in map view and vertical section. The upper model boundary at the water table includes areally distributed recharge. Surface runoff from the adjacent mountains was simulated as additional recharge (specified fluxes) along their base (the northwestern and southeastern parts of the modeled area), where the glacial sediments pinch out. Springs flowing from the adjacent mountains into the glacial sediments were represented in the model as specified fluxes. Picatinny Lake, the Rockaway River, Green Pond Brook, Bear Swamp Brook, and drainage ditches were represented as head-dependent leakage boundaries. A head value equal to the stream or lake-surface altitude and a hydraulic-conductance term representing the hydraulic connection between the stream or lake and the aquifer were assigned to control flow to this boundary. The lateral boundaries in the glacial sediments and bedrock at Picatinny Lake and southwest of the Rockaway River are no-flow boundaries. Ground water that does not discharge to Green Pond Brook, Bear Swamp Brook, or the unnamed pond flows down the valley (southwestward) and is assumed to discharge to the Rockaway River. Lateral flow from the bedrock to the glacial sediments at the valley wall was assumed to be negligible and was simulated as a no-flow boundary. The lower boundary, the bottom of the permeable bedrock, is a no-flow boundary. The thickness of the permeable-bedrock aquifer was assumed to be $300 \mathrm{ft}$ on the basis of the general tendency toward a decrease in the permeability of fractured bedrock with increasing depth. Results of previous work on carbonate terrain indicate that the number of fractures in the carbonate rock (the type of bedrock underlying Picatinny Arsenal) decreases with depth (R.S. Nicholson, U.S. Geological Survey, written commun., 1991). 

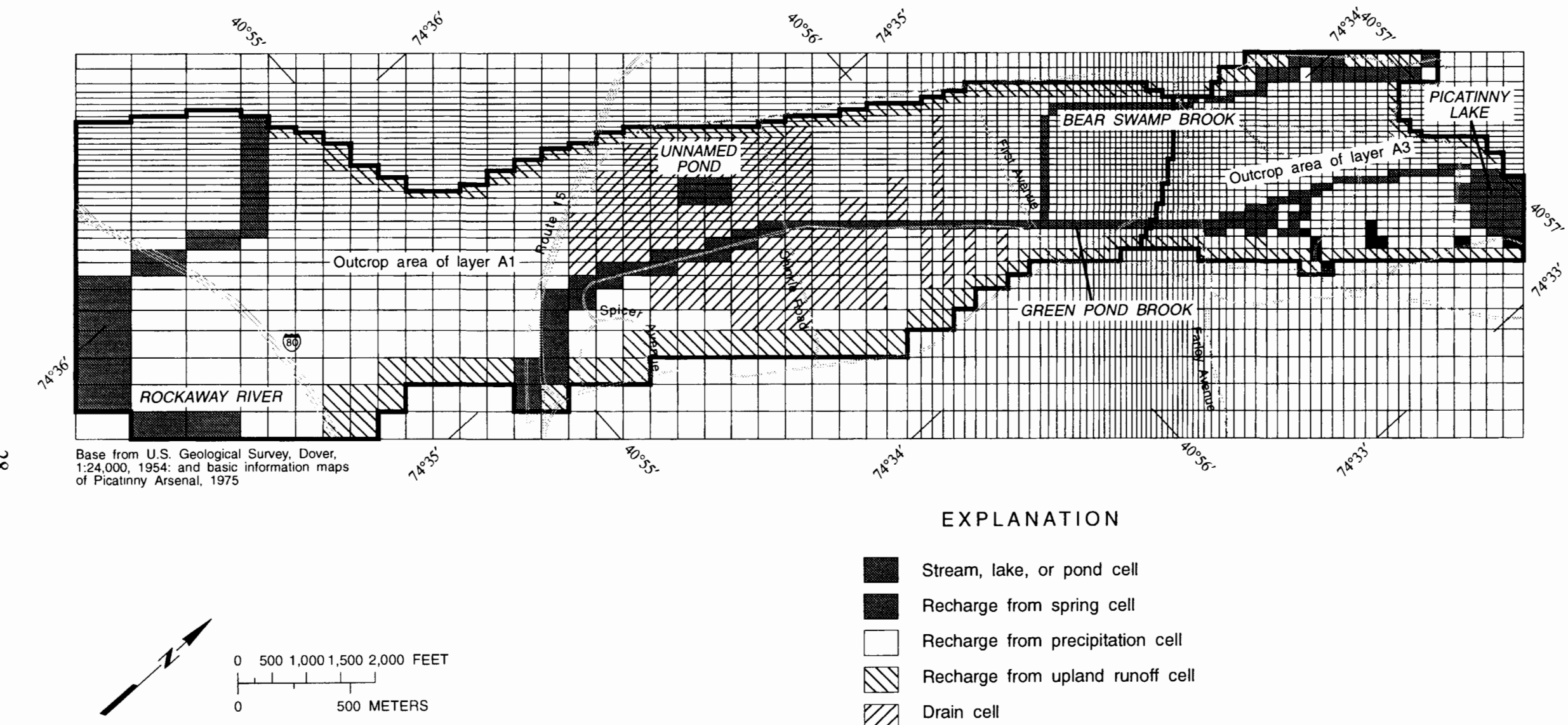

Stream, lake, or pond cell
Recharge from spring cell
Recharge from precipitation cell
Recharge from upland runoff cell
Drain cell

Figure 19. Finite-difference grid and location of model boundaries for the water-table aquifer used in the valley-wide ground-water-flow model, Picatinny Arsenal and vicinity, New Jersey. 


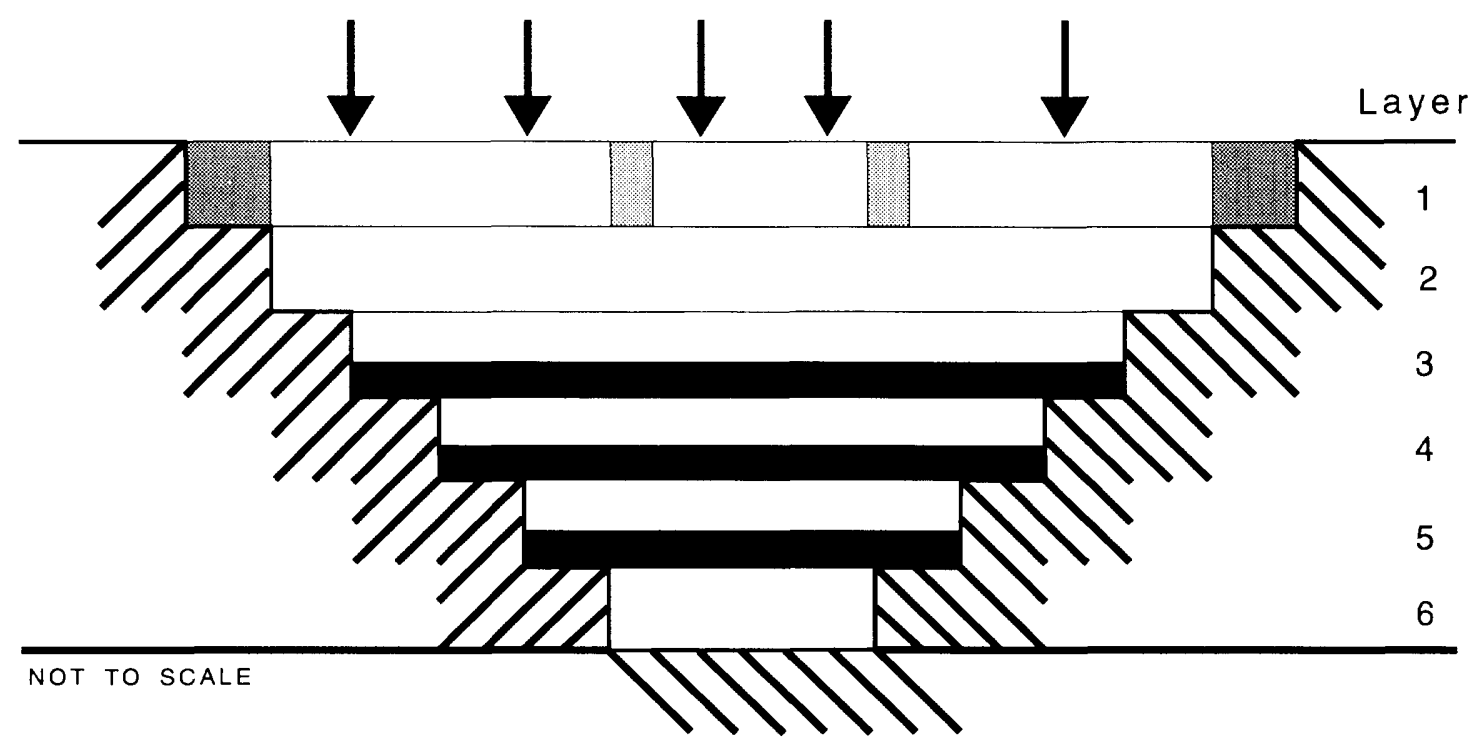

$$
\text { EXPLANATION }
$$

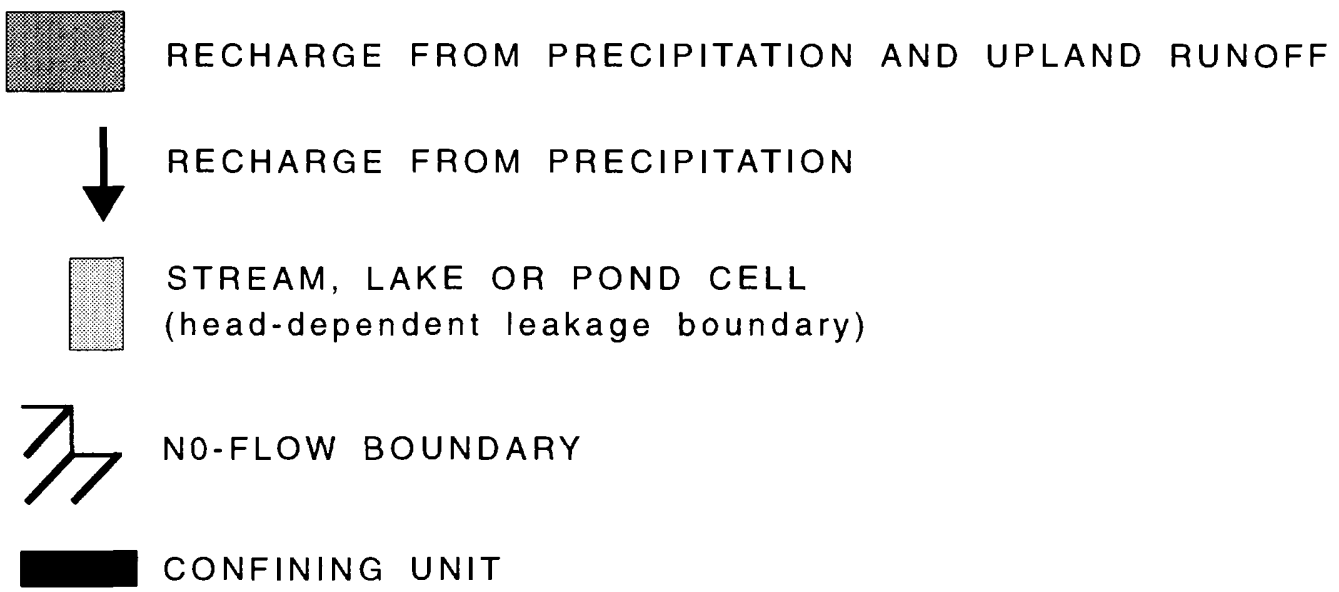

Figure 20. Diagrammatic vertical section showing model boundaries used in the valley-wide ground-water-flow model, Picatinny Arsenal and vicinity, New Jersey. 


\section{Data Requirements and Input}

The McDonald-Harbaugh modular three-dimensional finite-difference groundwater-flow model consists of a main program and a series of independent subroutines called modules. The construction of the ground-water-flow model for Picatinny Arsenal required the following modules: basic package, block-centered flow, output control, recharge, river, well, drain, and the Preconditioned Conjugate-Gradient 2 matrix-equation solver (Hill, 1990). Each of these modules requires specific data, which are discussed below.

Recharge.--Recharge from precipitation and recharge from upland runoff were simulated in the model. The recharge rate from precipitation for the model was estimated from precipitation and base-flow data and recharge rates reported by Lyford and Cohen (1988, table 1) for sand and gravel aquifers in the glaciated northeastern United States. The average amount of recharge entering the ground-water-flow system is approximately 45 percent of the average precipitation. The average precipitation calculated from data collected at the National Oceanic and Atmospheric Administration station at Split Rock, N.J., during 1948-92 is $50 \mathrm{in} / \mathrm{yr}$. A recharge rate of $22 \mathrm{in} / \mathrm{yr}$ was used in the model.

The second component of recharge is recharge from upland runoff. The topography of the adjacent mountains is such that the precipitation falling in this area is channeled down the slopes of the mountains in a specific path. Adequate representation of the additional recharge from upland runoff first required adequate representation of the drainage basins on the adjacent mountains. To begin, the model grid was overlain on a map of the drainage basins, and the model nodes that represented the area at the base of each basin were identified. The area of each drainage basin was then calculated. Runoff from each basin was estimated by multiplying the area of each basin by the average recharge rate ( $22 \mathrm{in} / \mathrm{yr})$. The estimated runoff was then applied as a specified flux to each of the model nodes that represented the area at the base of each basin. The specified fluxes used in the steady-state model to represent upland runoff ranged from $1.8 \times 10^{-6}$ to $0.09 \mathrm{ft}^{3} / \mathrm{s}$.

Lakes, streams, and springs.--The river module was used to simulate Picatinny Lake, the Rockaway River, Green Pond Brook, and Bear Swamp Brook in the model. This module provides the capability to represent the streams as gaining or losing and to convert from one to the other as hydrologic conditions change. Stream altitudes for Green Pond Brook and Bear Swamp Brook were estimated from a stream survey done in 1989. Constant heads for the Rockaway River were estimated from flood-insurance-study maps (Federal Emergency Management Agency, 1984). The hydraulic conductivity of the streambed material was initially assumed to be equal to the average horizontal hydraulic conductivity of the water-table aquifer, $200 \mathrm{ft} / \mathrm{d}$, and was later refined during model 
calibration. Model-calibrated hydraulic conductivity of the streambed material ranged from 0.86 to $172 \mathrm{ft} / \mathrm{d}$. The thickness of the streambed and the width of the streams were estimated from field inspection.

Springs on the adjacent mountains were located in the field, and the discharges from the springs were measured during January 1993. Spring discharge was represented as a specified flux (fig. 19). These specified fluxes ranged from 0.00875 to $0.085 \mathrm{ft}^{3} / \mathrm{s}$.

Drainage ditches.--The drain module was used to simulate the drainage ditches that drain the southern part of the arsenal. The drain module requires the following data: layer, row, column, and altitude of the drainage ditch; and the hydraulic conductance representing the hydraulic connection between the drainage ditch and the aquifer. The altitudes of the drainage ditches were estimated from a map of land-surface altitudes and were later selectively verified in the field. The vertical hydraulic conductivity of the bottom sediments of each drainage ditch was assumed to equal the horizontal hydraulic conductivity of the underlying aquifer layer.

Horizontal hydraulic conductivities.--Initial horizontal hydraulic conductivities of the permeable layers at Picatinny Arsenal and vicinity were estimated from the analysis of gamma-ray logs, aquifer-test results, cuttings from test borings, results of slug tests (Sargent and others, 1990), and horizontal hydraulic conductivities published for glacial sediments (Meisler, 1976). Results of slug tests done by Sargent and others (1990) indicate a large areal and vertical variation, 0.5 to $195 \mathrm{ft} / \mathrm{d}$, in the horizontal hydraulic conductivities of the water-table aquifer in the building 24 area (an area of approximately $0.2 \mathrm{mi}^{2}$ ). Hill and others (1990) also report a large areal variation in calibrated horizontal hydraulic conductivities of a water-table aquifer in a glaciated valley in the Ramapo River Valley, N.J.; horizontal hydraulic conductivities ranged from 100 to $1,700 \mathrm{ft} / \mathrm{d}$ for the simulated water-table aquifer and from 120 to $860 \mathrm{ft} / \mathrm{d}$ for the simulated confined aquifer. Sargent and others (1990) report a transmissivity of $6,867 \mathrm{ft}^{2} / \mathrm{d}$ for the confined glacial aquifer (A5; fig. 10) derived from an aquifer test done in 1983 at Picatinny Arsenal production well 129 (well 27-81 in this report; fig. 2). If an aquifer thickness of $60 \mathrm{ft}$ is assumed, then the horizontal conductivity of the confined glacial aquifer in the vicinity of well 129 is $114 \mathrm{ft} / \mathrm{d}$. Because horizontal hydraulic conductivities of the bedrock in this area were not available, this characteristic was estimated to be $10 \mathrm{ft} / \mathrm{d}$ on the basis of data for carbonate bedrock in other areas (Meisler, 1976). Initial horizontal hydraulic conductivities were adjusted during model calibration; final values are shown in figures 21 though 25 . Horizontal hydraulic conductivities as low as $10 \mathrm{ft} / \mathrm{d}$ are found in areas where the sediments contain some fine sand and (or) silts; horizontal hydraulic conductivities as high as $380 \mathrm{ft} / \mathrm{d}$ are found in areas where the sediments consist of coarse sand and (or) gravel and boulders. 


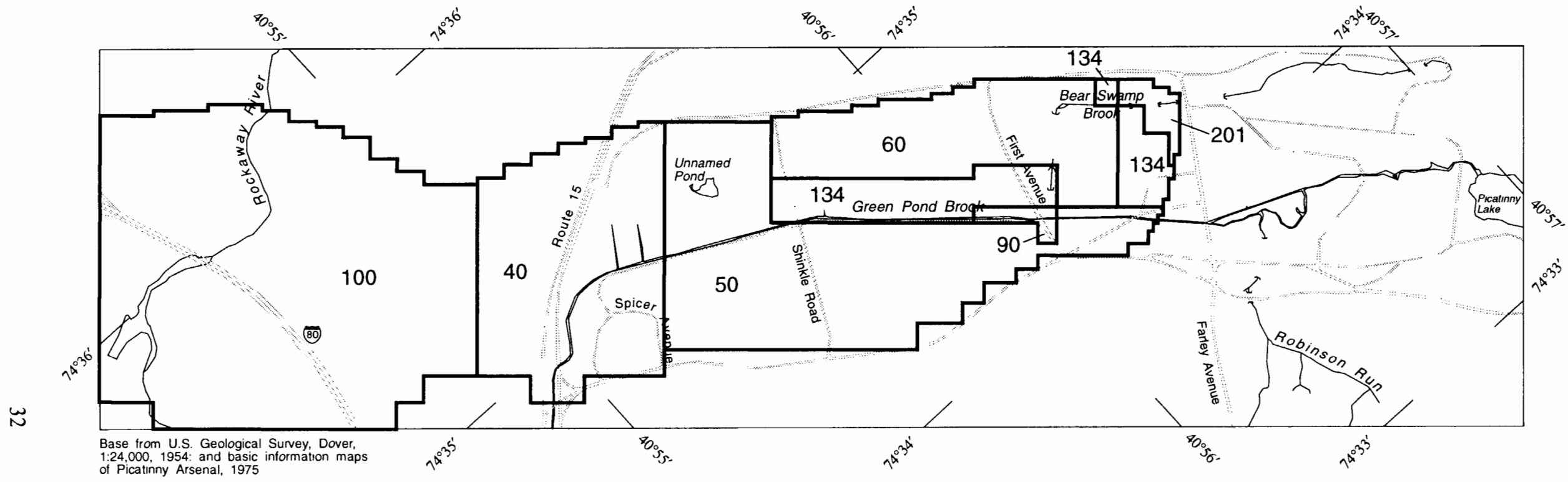

EXPLANATION

60 HYDRAULIC CONDUCTIVITY, IN FEET PER DAY

$0 \quad 5001,0001,5002,000$ FEET

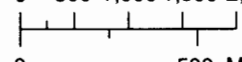

Figure 21. Areal distribution of horizontal hydraulic conductivities used to simulate ground-water flow in model layer A1, Picatinny Arsenal and vicinity, New Jersey. 


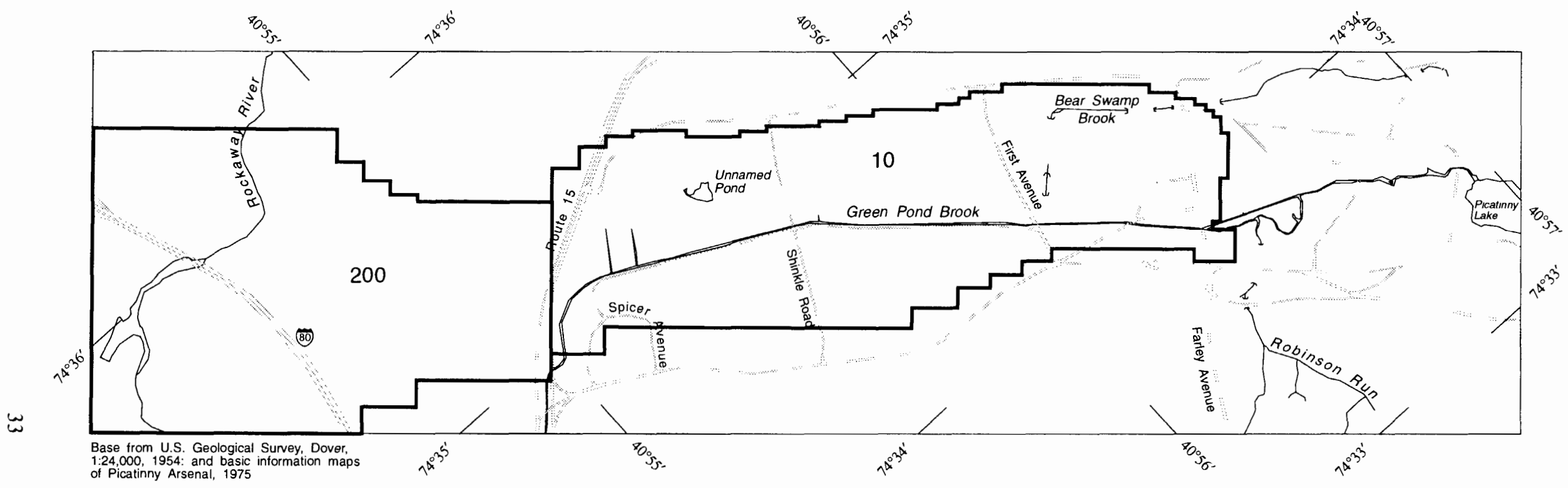

EXPLANATION

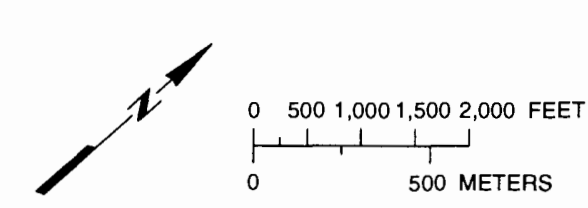

10 HYDRAULIC CONDUCTIVITY, IN FEET PER DAY

Figure 22. Areal distribution of horizontal hydraulic conductivities used to simulate ground-water flow in model layer A2, Picatinny Arsenal and vicinity, New Jersey. 


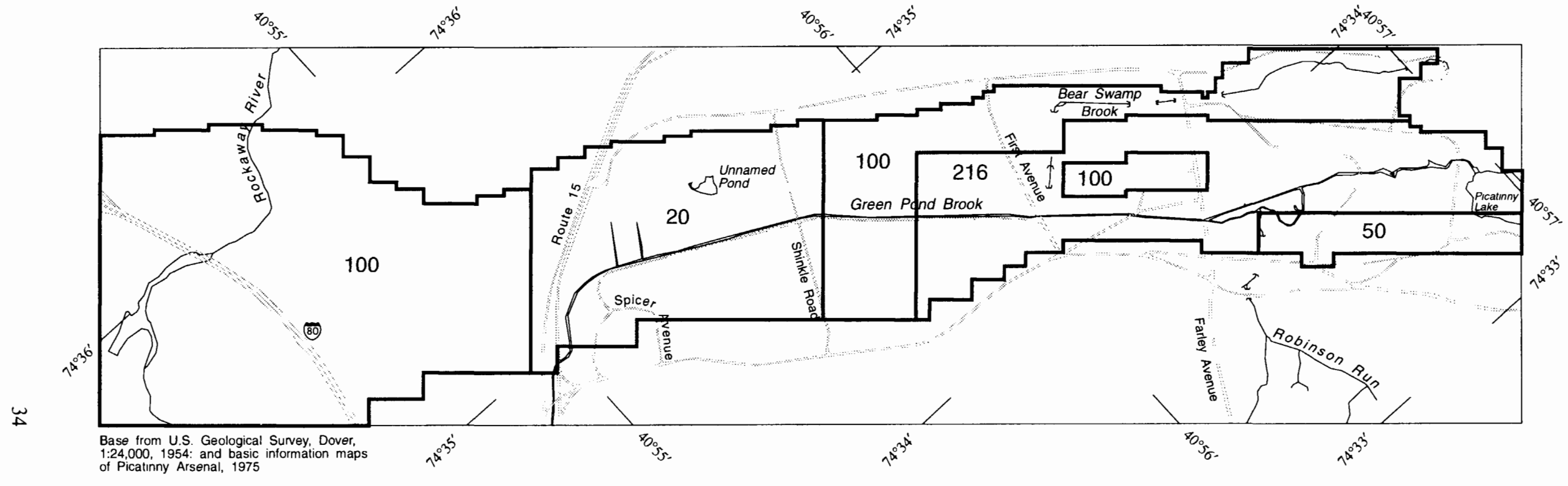

\section{EXPLANATION}

20 HYDRAULIC CONDUCTIVITY, IN FEET PER DAY

$5001,0001,5002,000$ FEET

500 METERS

Figure 23. Areal distribution of horizontal hydraulic conductivities used to simulate ground-water flow in model layer A3, Picatinny Arsenal and vicinity, New Jersey. 


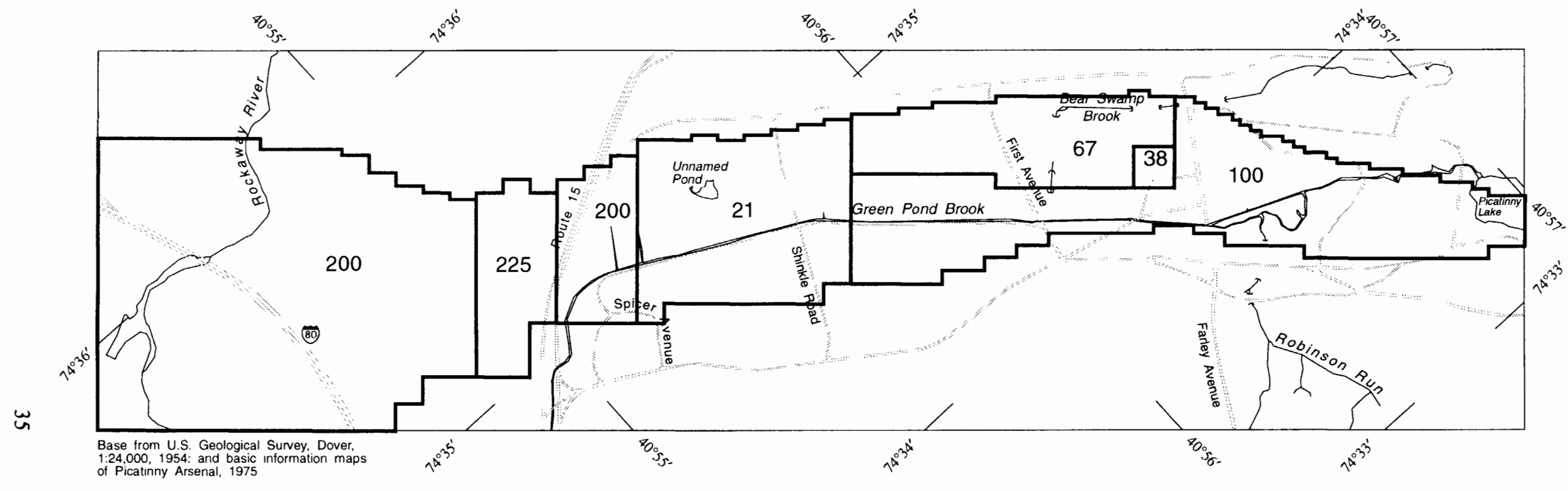

EXPLANATION

21 HYDRAULIC CONDUCTIVITY, IN FEET PER DAY

$0 \quad 5001,0001,5002,000$ FEET $\vdash, 1,1,1$

$0 \quad 500$ METERS

Figure 24. Areal distribution of horizontal hydraulic conductivities used to simulate ground-water flow in model layer A4, Picatinny Arsenal and vicinity, New Jersey. 


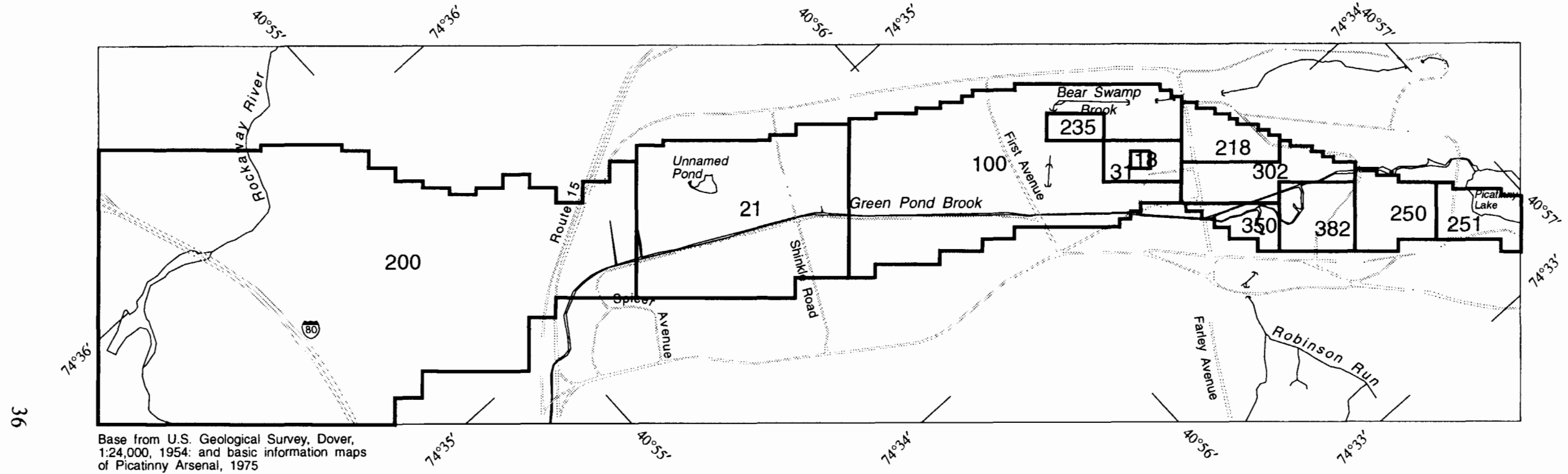

\section{EXPLANATION}

21 HYDRAULIC CONDUCTIVITY, IN FEET PER DAY

$0 \quad 5001,0001,5002,000$ FEET

$1+1,1,1$

500 METERS

Figure 25. Areal distribution of horizontal hydraulic conductivities used to simulate ground-water flow in model layer A5, Picatinny Arsenal and vicinity, New Jersey. 
Vertical leakance.--The vertical hydraulic conductivity of each confining unit was divided by the thickness of the layer to determine the vertical leakance. Initial vertical hydraulic conductivities in the low-permeability layers were based on the analysis of gamma-ray and lithologic logs of selected wells at Picatinny Arsenal and aquifer tests done at wells 129 and 410 (wells 27-81 and 27-86 in this report; fig. 2). Sargent and others (1990) report a vertical hydraulic conductivity of $0.065 \mathrm{ft} / \mathrm{d}$ for the confining unit overlying the confined glacial aquifer (A5) from their analysis of an aquifer test at well 129 in 1983. Layers with a high clay and (or) silt content were assigned a vertical hydraulic conductivity of $0.01 \mathrm{ft} / \mathrm{d}$. Layers with less clay or silt were assigned a vertical hydraulic conductivity of 0.05 to $0.7 \mathrm{ft} / \mathrm{d}$, depending on the amount of sand present. During model calibration, the hydraulic conductivities were adjusted; final vertical hydraulic conductivities are shown in figures 26 and 27 for confining units $\mathrm{C} 1$ and $\mathrm{C} 2$, respectively. Vertical hydraulic conductivities of the weathered bedrock layer were not varied areally, and a value of $0.5 \mathrm{ft} / \mathrm{d}$ was used in the model.

Withdrawals.--Ground-water-withdrawal data for the three production wells (410, 430A, and 129) in use at the arsenal during 1981-93 were compiled from daily records. Ground-water withdrawals at the arsenal have fluctuated through time and were less than $0.6 \mathrm{Mgal} / \mathrm{d}$ from January 1980 through March 1989, rose to $0.98 \mathrm{Mgal} / \mathrm{d}$ in August 1989, and reached a maximum of $1.3 \mathrm{Mgal} / \mathrm{d}$ in December 1989. The two main production wells in use at the arsenal during 1981-89, well 410 (27-86) and well 430A (27-84), are near Picatinny Lake (fig. 2). Each of these production wells has a withdrawal capacity of 350 $\mathrm{gal} / \mathrm{min}$. Production well 129 (27-81), near Farley Avenue (fig. 2), has a withdrawal capacity of $450 \mathrm{gal} / \mathrm{min}$. Pumping from this well was intermittent until July 1989 . All production wells are screened in model layer A5, the lowermost glacial aquifer. Average withdrawals of $222.36,197.22$, and $238.68 \mathrm{gal} / \mathrm{min}$ were used in the model for wells 129 , $439 \mathrm{~A}$, and 410 , respectively.

\section{Simulated Average Hydrologic Conditions, 1989-93}

The ground-water-flow model was calibrated by simulating the steady-state conditions assumed to exist during 1989-93. Simulated water levels were compared to water levels measured during January 19-22, 1993, a time considered to represent average conditions for 1989-93. In figure 28, the long-term water-level hydrograph for well 27-95 indicates that the water level measured in January 1993 represents water levels that are about $1 \mathrm{ft}$ higher than the average water level for well 27-95; therefore, the calibrated steady-state model, representing average 1989-93 conditions, should simulate water levels slightly ( $1 \mathrm{ft})$ lower than those measured in January 1993.

In January 1993, water levels in 166 wells were measured at Picatinny Arsenal. Some of the wells that were measured are screened in layers that are designated as confining units in the model. Of the 166 wells measured, 155 were used to calibrate the steady-state model. Locations of the wells used to calibrate the ground-water-flow model 


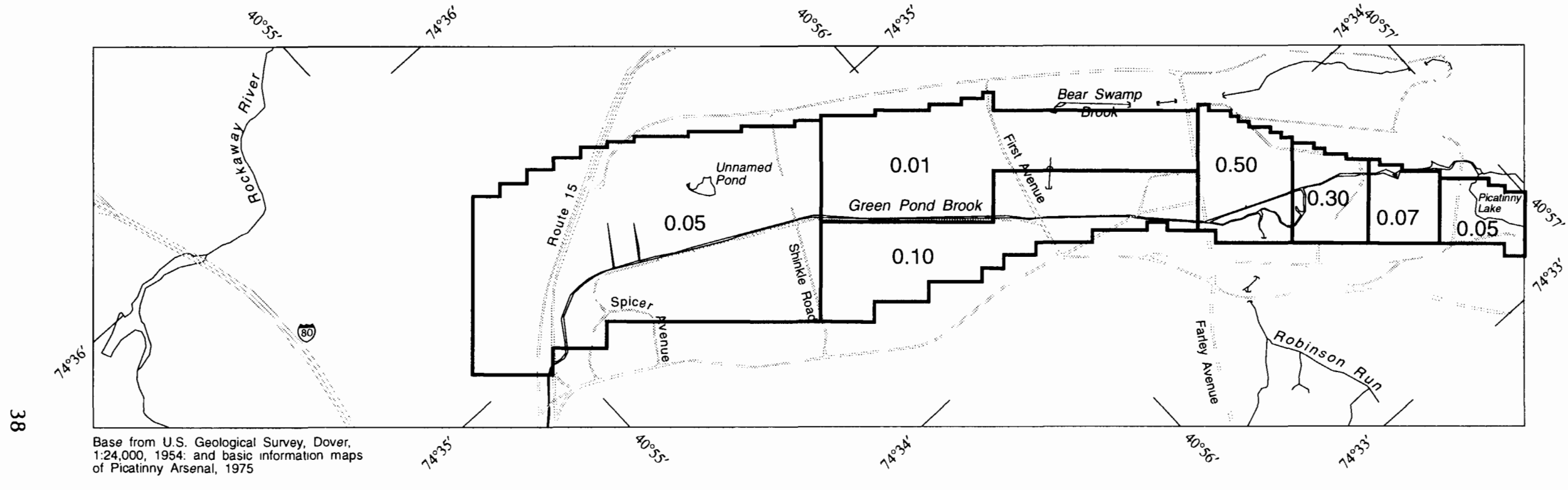

\section{EXPLANATION}

0.01 HYDRAULIC CONDUCTIVITY, IN FEET PER DAY $0 \quad 5001,0001,5002,000$ FEET

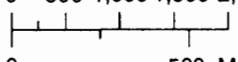

$0 \quad 500$ METERS

Figure 26. Areal distribution of vertical hydraulic conductivities used to simulate ground-water flow in model layer $\mathrm{C} 1$, Picatinny Arsenal and vicinity, New Jersey. 


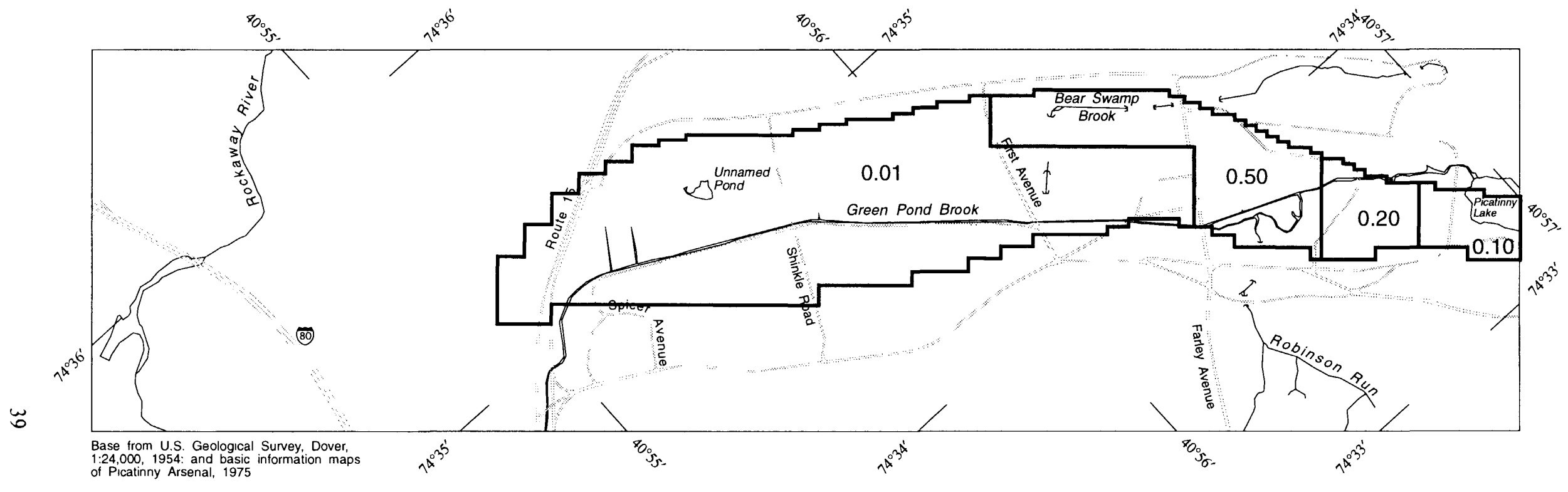

EXPLANATION

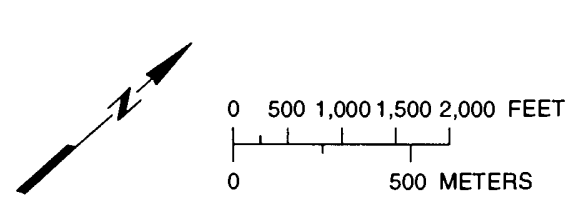

0.01 HYDRAULIC CONDUCTIVITY, IN FEET PER DAY

Figure 27. Areal distribution of vertical hydraulic conductivities used to simulate ground-water flow in model layer C2, Picatinny Arsenal and vicinity, New Jersey. 


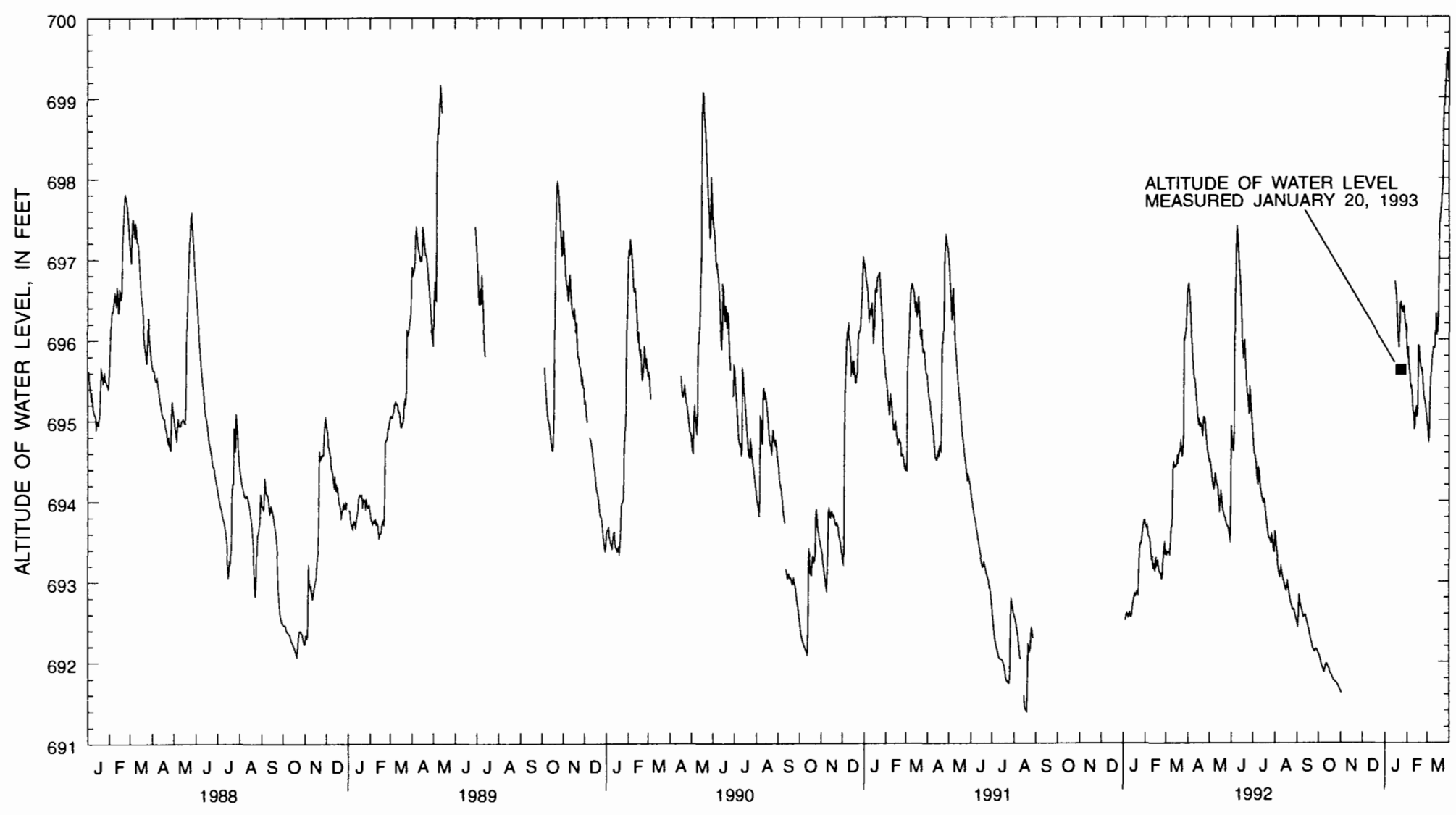

Figure 28. Water-level hydrograph of well 27-95 (9C), January 1988-March 1993, and water level measured on January 20, 1993, Picatinny Arsenal, New Jersey. 
are shown on plate 1. Water levels in confining layers are not generated by the modular model. Streamflow measurements made at five sites on Green Pond Brook on January 19 and 20,1993, were used for comparison with simulated discharge to appropriate model stream cells during model calibration.

During model calibration, horizontal and vertical hydraulic conductivities of aquifers and confining units and hydraulic conductivity of stream boundaries were adjusted to achieve a close match between the simulated and measured water levels, ground-water-head differences at well clusters, and streamflow. Calibration was considered to be satisfactory when simulated water levels were similar to the measured water levels, the simulated streamflows were similar to the measured inflow to and outflow from Green Pond Brook, and the simulated head differences at well clusters were similar to measured head differences.

During model calibration, water levels measured at wells near the valley walls and screened at the water table were compared to simulated water levels. A close match between the simulated and measured water levels in these areas was achieved, and the specified fluxes representing the upland runoff were not adjusted during model calibration.

As part of the calibration procedure, a sensitivity analysis of hydraulic parameters was done to evaluate the data and the effect of assumptions on the simulated results. For this model, recharge and, to a lesser extent, lakebed, aquifer, and confining-unit hydraulic conductivities of the glacial sediment were the most sensitive parameters. During model calibration, the recharge rate calculated from streamflow data was not adjusted. Hydraulic conductivities of the glacial sediments were adjusted during model calibration to within the range reported for glacial sediments (Meisler, 1976; Hill and others, 1990; Sargent and others, 1990).

\section{Water Levels}

The simulated potentiometric surfaces for the 1989-93 steady-state simulation are shown in figures 29 through 34 . Also shown in the figures is the location of observation wells for which the difference between the simulated and measured water levels is given in table 3. Locations and well numbers for wells in figures 29 through 34 are shown on plate 1. Because the steady-state ground-water-flow model approximates average 1989-93 conditions and the January 1993 water levels are representative of ground-water conditions that are slightly higher than average 1989-93 conditions, the simulated water levels should be lower than the January 1993 water levels (indicated as a negative difference in table 3). All measured water levels made in January 1993 were simulated to within $5 \mathrm{ft}$ of the measured water levels, except for one measurement from well 10-3A (27-968), which is screened in the bedrock. Herman and Mitchell (1991, pl. 1) show the Picatinny fault to be near well 10-3A. Well 10-3A could be affected by local fractures, and water levels in this well may not be representative of water levels in the bedrock. 


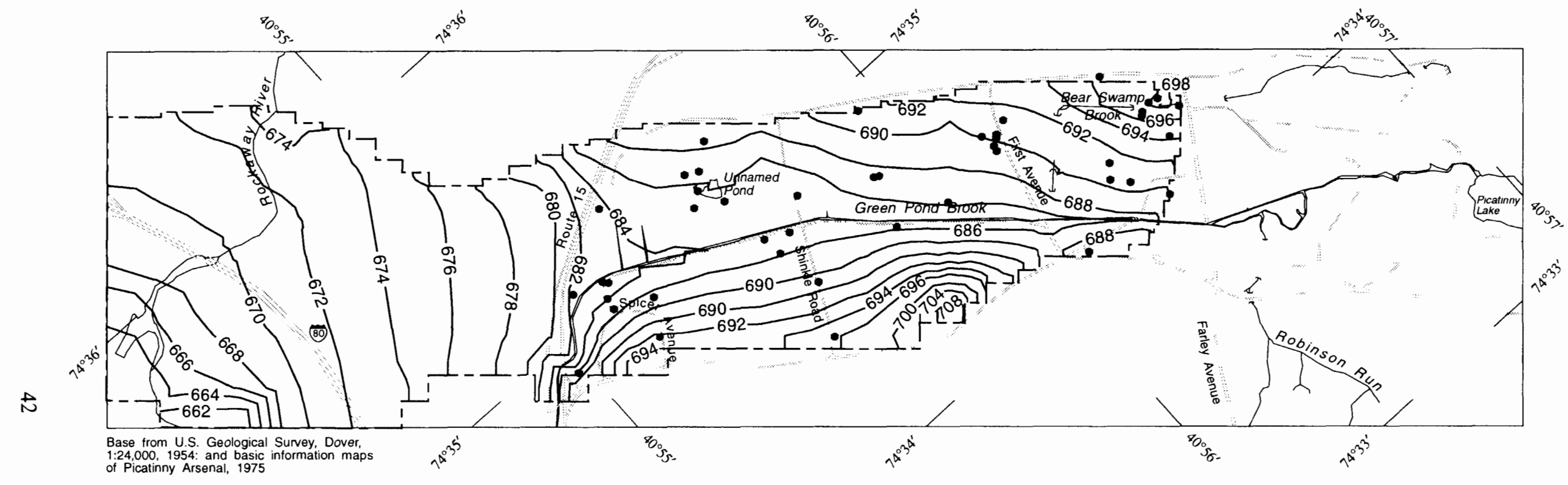

EXPLANATION
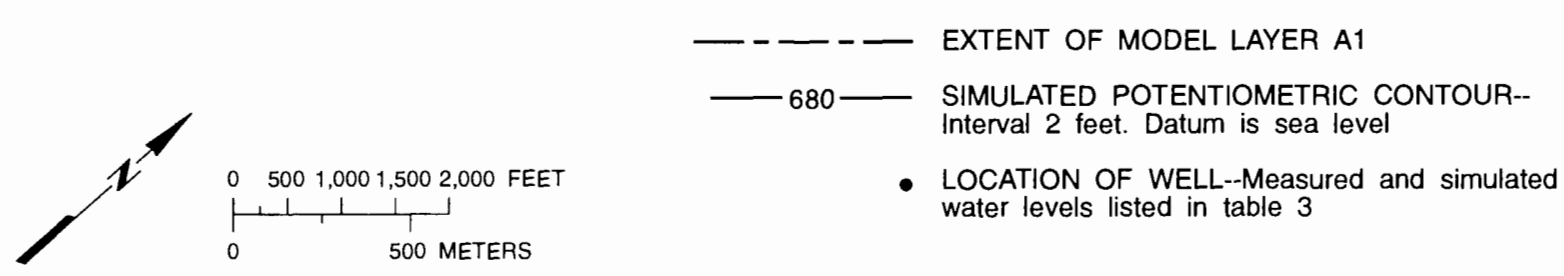

Figure 29. Simulated potentiometric surface of model layer A1, Picatinny Arsenal and vicinity, New Jersey. 


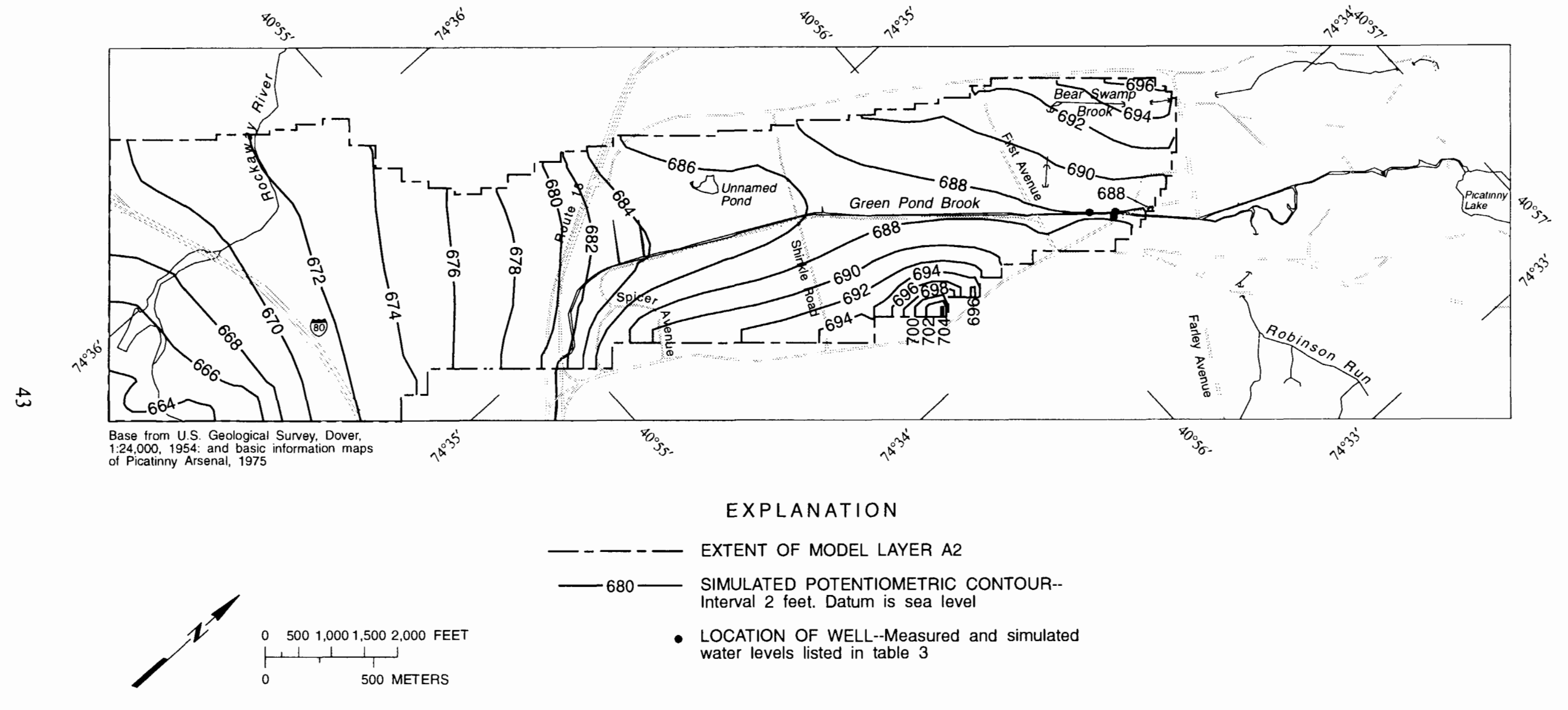

Figure 30. Simulated potentiometric surface of model layer A2, Picatinny Arsenal and vicinity, New Jersey. 


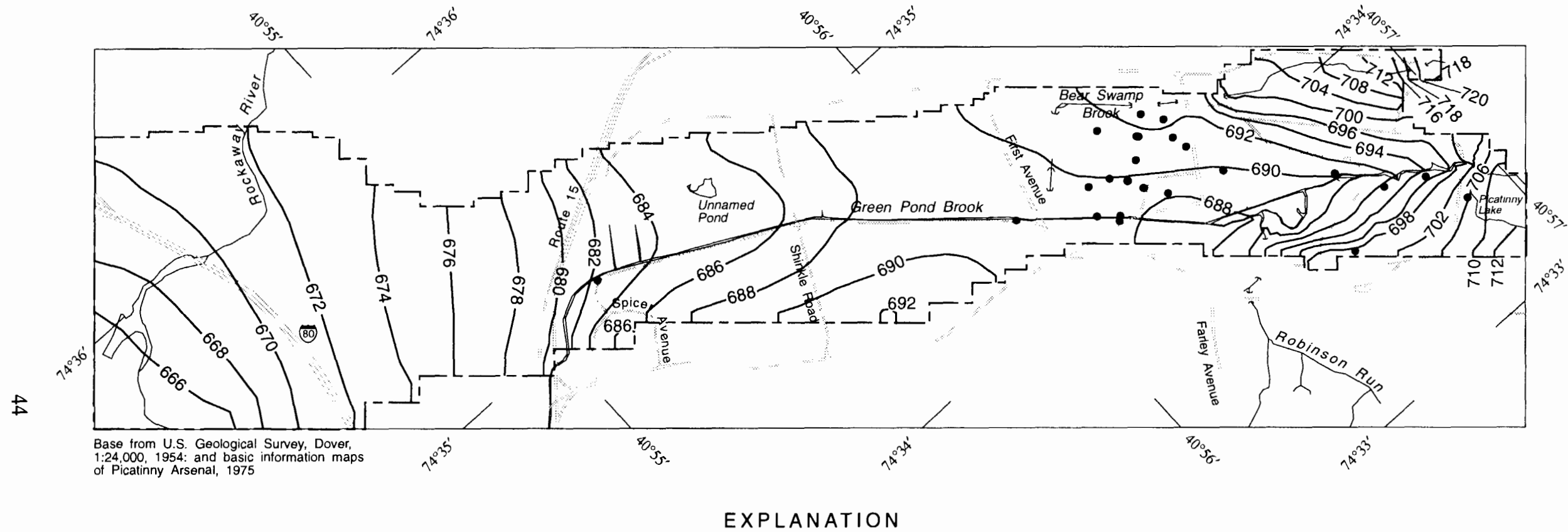

EXPLANATION

---- EXTENT OF MODEL LAYER A3

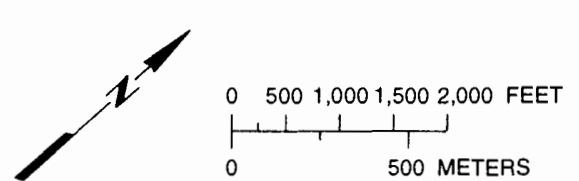

SIMULATED POTENTIOMETRIC CONTOUR--

interval, in feet, is variable. Datum is sea leve

- LOCATION OF WELL--Measured and simulated water levels listed in table 3

Figure 31. Simulated potentiometric surface of model layer A3, Picatinny Arsenal and vicinity, New Jersey. 


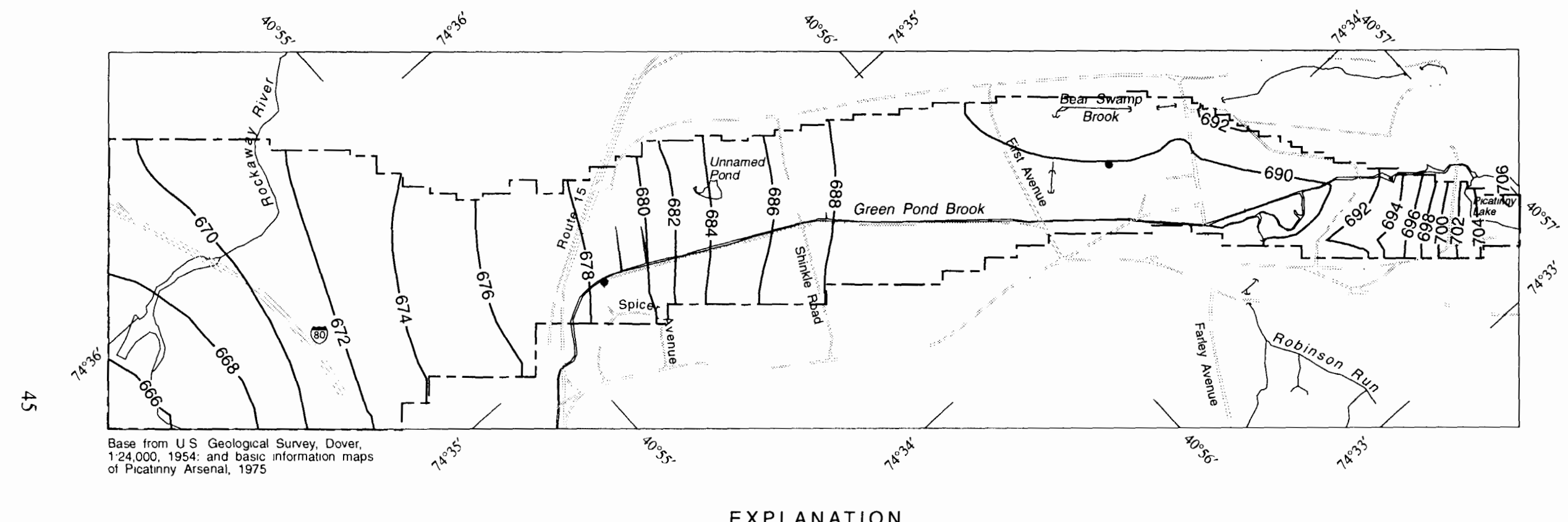

\section{EXPLANATION}

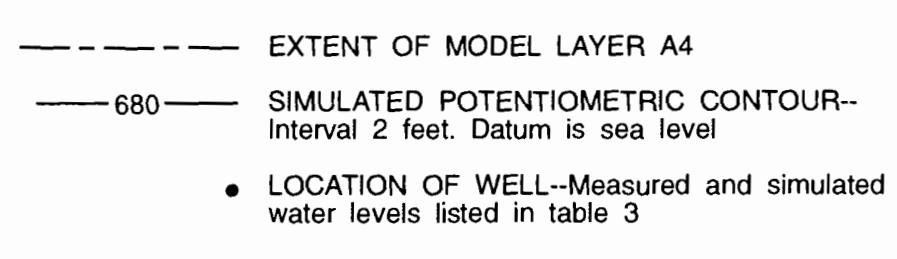

Figure 32. Simulated potentiometric surface of model layer A4, Picatinny Arsenal and vicinity, New Jersey. 


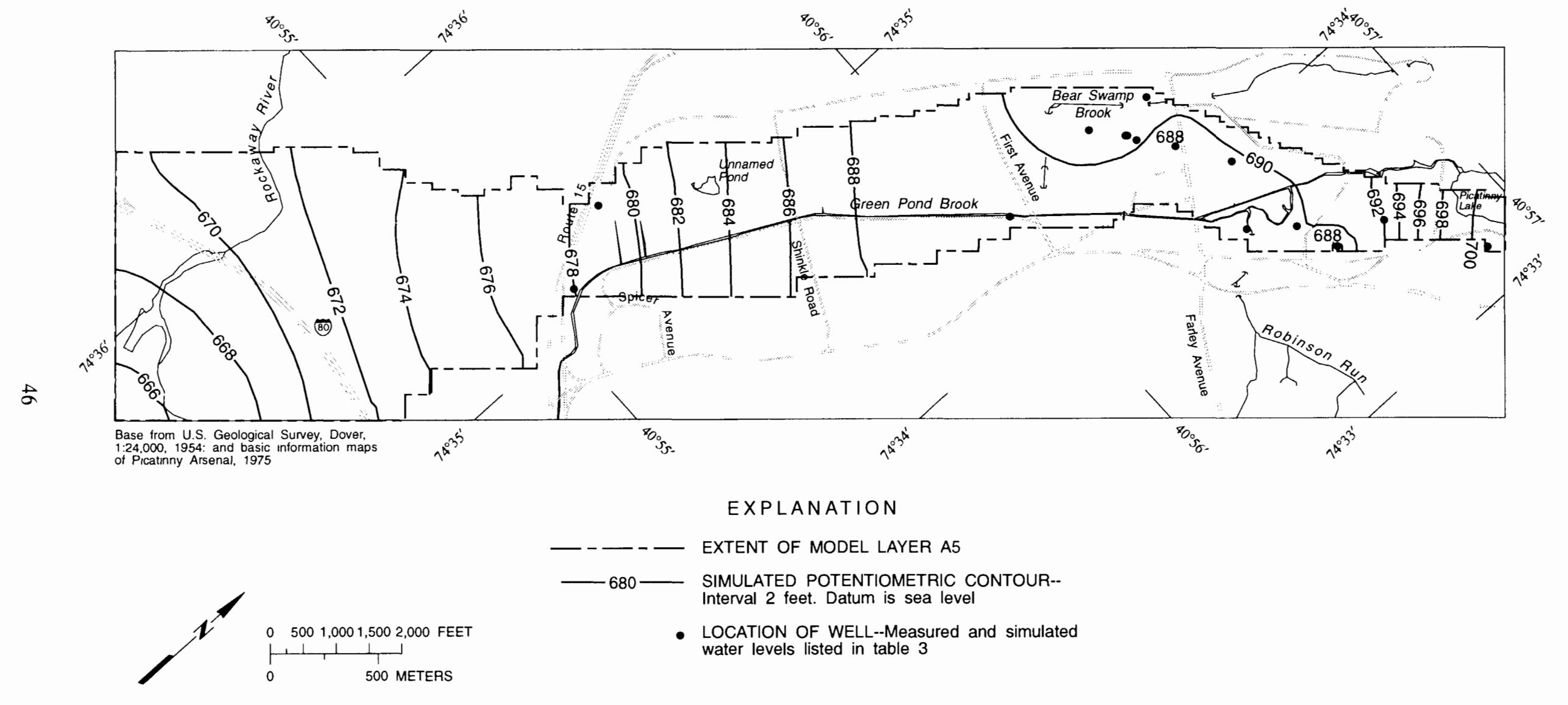

Figure 33. Simulated potentiometric surface of model layer A5, Picatinny Arsenal and vicinity, New Jersey. 


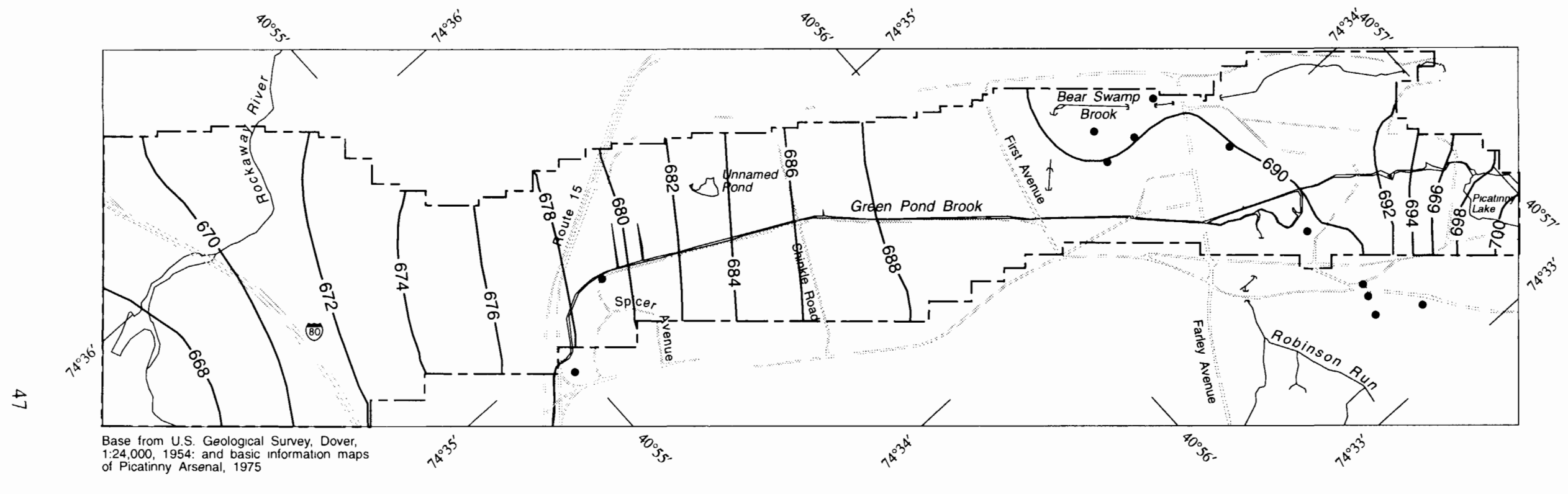

\section{EXPLANATION}

\section{EXTENT OF MODEL LAYER A6}

SIMULATED POTENTIOMETRIC CONTOUR-Interval 2 feet. Datum is sea level

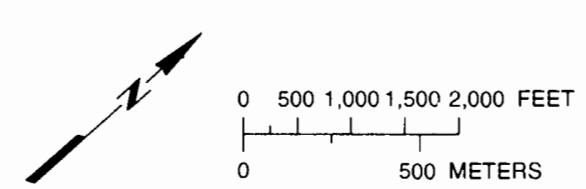

- LOCATION OF WELL--Measured and simulated water levels listed in table 3

Figure 34. Simulated potentiometric surface of model layer A6, Picatinny Arsenal and vicinity, New Jersey. 
The simulated potentiometric surface for model layer A1 is shown in figure 29. Ground-water flow in model layer A1 between First Street and Shinkle Road is toward Green Pond Brook, with a slight downvalley component. A ground-water divide is present northeast of Route 15 at the southern boundary of the arsenal. Northeast of Route 15, ground water in model layer A1 flows toward the arsenal, Green Pond Brook, and a small unnamed pond (fig. 29). Northwest of the ground-water divide, ground water flows down the valley toward the Rockaway River.

The steady-state simulated potentiometric contours in model layers A2 and A3 are shown in figures 30 and 31, respectively. Ground water between First Street and Shinkle Road in permeable model layers A2 and A3 flows toward Green Pond Brook; however, a downvalley component is present. Ground-water flow in layer A3 northwest of Farley Avenue is toward Green Pond Brook. There is a small discontinuity in the water-table surface between layers $\mathrm{A} 1$ and $\mathrm{A} 3$ because layer $\mathrm{A} 2$, which has lower permeability than both layers A1 and A3, rises across the water table (fig. 10). Ground-water-flow directions near Route 15 are southwestward to the Rockaway River and are similar to those in permeable model layer A1.

The steady-state simulated potentiometric surface in model layer A4 is shown in figure 32. A ground-water divide is present in model layer A4 about midway between First Street and Farley Avenue. South of the ground-water divide, ground water flows down the valley to the Rockaway River. North of the ground-water divide and west of Green Pond Brook, ground-water flow is to Green Pond Brook with a slight upvalley component. This upvalley component of flow is probably attributable to the extent of the overlying confining unit. The confining unit pinches out and does not extend to the valley wall. This breach in the confining unit permits downward flow into layer A4 and causes a local high in the potentiometric surface. East of Green Pond Brook and north of Farley Avenue, ground water flows to Green Pond Brook. This flow-direction anomaly is probably caused by a similar but smaller scale phenomenon on the opposite side of the valley. In the extreme northern part of the study area, ground water flows directly downvalley from Picatinny Lake. Again, south of the southern boundary of the arsenal, flow is toward the Rockaway River.

Average 1989-93 steady-state simulated potentiometric surfaces in permeable model layers A5 (the lowermost confined glacial aquifer) and A6 (the bedrock aquifer) are shown in figures 33 and 34, respectively. Ground-water-flow directions in these two layers are nearly identical. Ground water flows downvalley to the Rockaway River in both layers except between First and Ninth Streets, where ground water flows toward Green Pond Brook and production well 129. The broad zone in the central part of the arsenal where horizontal gradients are very low (that is, between the 688 - and 690 - $\mathrm{ft}$ contours) is probably caused by the local potentiometric high that overlies this area in layer A4 and the low horizontal hydraulic conductivities between Shinkle Road and Route 15 in layers A4 and A5. 
The measured head differences (January 1993) between the water-table-aquifer layers and the confined-aquifer layers were compared to simulation results at eight well clusters at the arsenal. Each well cluster consisted of at least two wells in close proximity; one well was screened in a water-table-aquifer layer (model layer A1, A2, or A3) and the other well was screened in a confined-aquifer layer (model layer A4, A5, or A6). The water level in the deepest well screened in the water-table aquifer was compared to the simulated head where more than one well in a well cluster was screened in the water-table aquifer. The level in the deepest well screened in the confined aquifer was compared to the simulated head where more than one well in a well cluster was screened in the confined aquifer.

Head differences in two well clusters (B65 and caf well) located between Farley Avenue and First Street (wells 27-246 through 27-249 and 27-242 through 27-245 on pl. 1) were similar. The measured head differences between the bottom water-table-aquifer layer (model layer A3) and the bedrock aquifer (model layer A6) in the B65 and caf well clusters were 2.79 and $3.38 \mathrm{ft}$, respectively. Ground-water flow is downward from the water-table aquifer to the bedrock aquifer. Simulated heads indicate similar flow directions at these two well clusters; head differences were $1.54 \mathrm{ft}$ for the B65 well cluster and $1.85 \mathrm{ft}$ for the caf well cluster.

Data from a well cluster (wells 27-970 and 27-971; pl. 1) adjacent to Green Pond Brook and just southwest of First Street indicate a slight downward head difference of $0.22 \mathrm{ft}$ between the water-table aquifer (model layer A3) and the confined glacial aquifer (model layer A5); however, water-level measurements made at these wells in December 1987 (Ground-Water Site Inventory data base, U.S. Geological Survey office, West Trenton, N.J.) indicate an upward head difference of $0.29 \mathrm{ft}$ during this time period. It appears that the direction of the vertical head difference at this well cluster oscillates over time. Simulated heads at this well cluster indicate an upward head difference of $0.25 \mathrm{ft}$. Data collected through time at this well cluster are not sufficient to determine the average head difference. This well cluster could be near the area in the confined glacial aquifers where ground-water flow directions change from discharging to Green Pond Brook to flowing downvalley and discharging to the Rockaway River. West of Shinkle Road and east of Route 15, measured water levels at five well clusters indicate the same downward head difference between the water-table aquifer and the confined aquifers, including areas adjacent to Green Pond Brook. Moreover, simulated heads indicate similar downward head difference, as shown in the following table: 


\begin{tabular}{lllcc}
\hline $\begin{array}{c}\text { Well-cluster } \\
\text { number or name }\end{array}$ & Model layer & Well number & $\begin{array}{c}\text { Measured head } \\
\text { difference (feet) }\end{array}$ & $\begin{array}{c}\text { Simulated head } \\
\text { difference (feet) }\end{array}$ \\
\hline \multirow{2}{*}{1179} & A2 & $27-1251$ & 6.73 & 1.95 \\
& A4 & $27-1252$ & & .39 \\
1180 & A2 & $27-1263$ & 6.07 & \\
& A4 & $27-1265$ & & 3.3 \\
Landfill & A3 & $27-251$ & 10.3 & 4.37 \\
wells & A6 & $27-250$ & & \\
SB2 & A1 & $27-1131$ & 7.26 & 4.06 \\
& A5 & $27-1130$ & & \\
\hline
\end{tabular}

\section{Stream Seepage}

The U.S. Geological Survey maintains two streamflow-gaging stations on Green Pond Brook at Picatinny Arsenal (fig. 2). One is $200 \mathrm{ft}$ downstream from (below) the dam on Picatinny Lake (U.S. Geological Survey station number 01379780). The other is at the southern boundary of the arsenal and $600 \mathrm{ft}$ upstream from the bridge on the northbound lane of Route 15 (U.S. Geological Survey station number 01379790); this station is referred to hereafter as the gaging station "at Wharton." The period of record for the gaging station below the dam on Picatinny Lake is from October 1984 to present (1993). The period of record for the gaging station at Wharton is from October 1982 to present. Both gaging stations are equipped to record stream stage continuously; streamflow is computed from the stream stage. Streamflow at the two U.S. Geological Survey gaging stations is field-measured every 6 or 12 weeks; these measurements are used to improve the accuracy of the streamflow computed from stage.

During the January 1993 ground-water-level measurements at Picatinny Arsenal, streamflow was measured at four sites on Green Pond Brook. Locations of the streamflowmeasurement sites are shown on plate 1 . Streamflow at this time was considered to be from ground-water discharge (base flow) and not from surface runoff. Stream stage at a nearby gaging station was checked just before the January 1993 ground-water-level measurements to confirm base-flow conditions.

The average 1984-93 base flow for Green Pond Brook (calculated from the continuous record) is $14.88 \mathrm{ft}^{3} / \mathrm{s}$ at the station below the dam at Picatinny Lake and 23.07 $\mathrm{ft}^{3} / \mathrm{s}$ at Wharton. Streamflow measured during the January 1993 ground-water-level measurements at these two sites was $17.9 \mathrm{ft}^{3} / \mathrm{s}$ below the dam at Picatinny Lake and 25.2 $\mathrm{ft}^{3} / \mathrm{s}$ at Wharton. Streamflow in January 1993 was slightly higher than the average base 
flow for the period of record, but can be used to calibrate the model. Simulated flow from or to the stream, when compared to the measured flow, should be lower than the measured flow.

A comparison of the simulated flows, January 1993 streamflow measurements, and the differences between streamflow measurements at selected sites on Green Pond Brook is given in table 4. No discharge measurements for the Rockaway River in the study area are available. The total measured gain in base flow to Green Pond Brook between discharge sites 9 and 17 (pl. 1) in January 1993 was $7.3 \mathrm{ft}^{3} / \mathrm{s}$. The average gain of base flow to Green Pond Brook between these sites calculated from the continuous data for 1984-93 is $8.19 \mathrm{ft}^{3} / \mathrm{s}$. The simulated gain is $7.66 \mathrm{ft}^{3} / \mathrm{s}$, which is close to both of the measured values.

Streamflow measurements made on January 19 and 20, 1993, at Green Pond Brook were used to define the variations in ground-water discharge to the brook. The data shown in table 4 show the brook to be gaining $2.76 \mathrm{ft}^{3} / \mathrm{s}$ between discharge-measurement sites 9 and 10 (pl. 1). Steady-state simulated flows between Green Pond Brook and the underlying sediments between discharge-measurement sites 9 and 10 were not simulated as closely as were the overall simulated flows for Green Pond Brook; however, the results are acceptable $\left(4.13 \mathrm{ft}^{3} / \mathrm{s}\right)$. Discharge measurements made at Green Pond Brook on January 19 and 20,1993 , show the brook to be gaining $2.4 \mathrm{ft}^{3} / \mathrm{s}$ between dischargemeasurement sites 13 and 17. Steady-state simulated flows show Green Pond Brook to be gaining $1.45 \mathrm{ft}^{3} / \mathrm{s}$ between sites 13 and 17 . The simulated flow is lower than the measured gain in streamflow but is acceptable. All other measured streamflows were matched closely by the steady-state model.

The steady-state simulated ground-water flow at each model node representing Bear Swamp Brook, Green Pond Brook, and the Rockaway River is shown in figure 35. Green Pond Brook gains ground water from the underlying sediments along most of its course through Picatinny Arsenal except at a few locations (black areas in figure 35) at the southern boundary of the arsenal and the location where Robinson Run enters Green Pond Brook. Bear Swamp Brook gains water from and loses water to the underlying sediments in its upper reaches on the arsenal property and then loses water to the underlying sediments beyond the building 24 area. The Rockaway River loses water to the underlying sediments in the northeastern half of the study area and then gains ground water from the underlying sediments in the southwestern half of the study area. 
Table 4. Steady-state simulated flows for selected reaches and measured discharge at selected sites, Green Pond Brook, Picatinny Arsenal, New Jersey

[All values are in cubic feet per second; --, not applicable]

\begin{tabular}{|c|c|c|c|c|c|c|}
\hline & $\begin{array}{c}\text { Discharge } \\
\text { measurements } \\
\text { at sites }\end{array}$ & & $\begin{array}{c}\text { Discharge } \\
\text { measurements } \\
\text { at sites }\end{array}$ & & $\begin{array}{c}\text { Discharge } \\
\text { measurements } \\
\text { at sites }\end{array}$ & \\
\hline Date & $9-17^{1}$ & $\begin{array}{c}\text { Difference }^{2} \\
\text { between sites }\end{array}$ & $0-10^{3}$ & $\begin{array}{c}\text { Difference }^{2} \\
\text { between sites }\end{array}$ & $10-12^{1}$ & $\begin{array}{l}\text { Difference } \\
\text { between sites }\end{array}$ \\
\hline Measurements during January $19-20,1993$ & $17.9-25.2$ & -7.3 & $17.29-20.05$ & -2.76 & $20.05-22.1$ & -2.05 \\
\hline Results from steady-state model & - & -7.66 & -- & -4.13 & - & -1.10 \\
\hline
\end{tabular}

\begin{tabular}{|c|c|c|c|c|}
\hline & $\begin{array}{c}\text { Discharge } \\
\text { measurements } \\
\text { at sites }\end{array}$ & & $\begin{array}{c}\text { Discharge } \\
\text { measurements } \\
\text { at sites }\end{array}$ & \\
\hline Date & $12-13^{1}$ & $\begin{array}{c}\text { Difference }^{2} \\
\text { between sites }\end{array}$ & $13-17$ & $\begin{array}{c}\text { Difference }^{2} \\
\text { between sites }\end{array}$ \\
\hline Measurements during January $19-20,1993$ & $22.1-22.8$ & -.7 & $22.8-25.2$ & -2.4 \\
\hline Results from steady-state model & -- & -1.14 & -- & -1.45 \\
\hline
\end{tabular}

\footnotetext{
${ }^{1}$ Numbers refer to location of discharge-measurement site shown in plate 1.

${ }^{2}$ Positive number indicates a loss of streamwater to the underlying aquifer; negative number indicates a gain of streamwater from the underlying aquifer.
} 


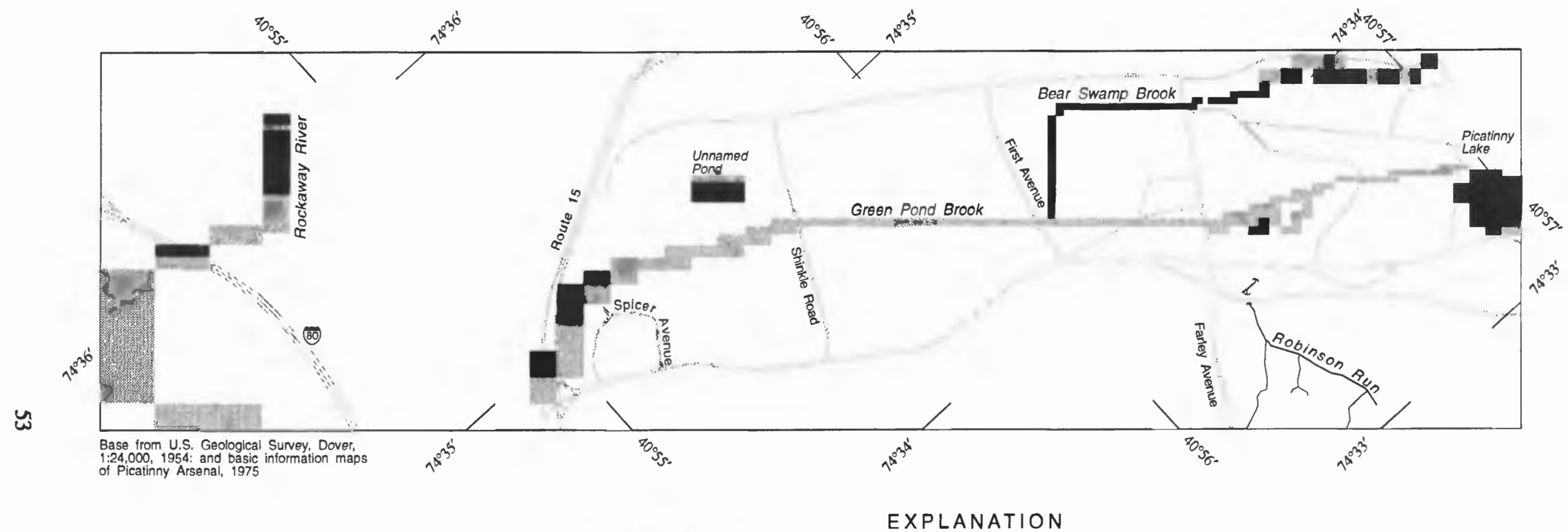

FLOW FROM STREAM, LAKE, OR POND TO UNDERLYING SEDIMENTS

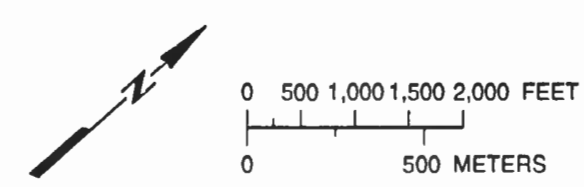

FLOW TO STREAM, LAKE, OR POND FROM UNDERLYING SEDIMENTS

Figure 35. Steady-state simulated flow for each model node for Bear Swamp Brook, Green Pond Brook, and Rockaway River, Picatinny Arsenal and vicinity, New Jersey. 


\section{System Budgets}

A summary of a steady-state ground-water budget calculated by use of the calibrated model is given in table 5. The major sources of water to the ground-water system are recharge from precipitation (34 percent of inflow) and runoff from the adjacent mountains (28 percent). Bear Swamp Brook, which carries water from uplands outside the modeled area, contributes 14 percent of inflow because it is a losing stream through virtually its entire reach (fig. 35). Seepage out of Picatinny Lake constitutes about 15 percent of inflow. Although Green Pond Brook is a gaining stream through most of its length, about 6 percent of inflow is contributed by a few losing reaches (fig. 35). Less than 3 percent of inflow is contributed as seepage from the Rockaway River.

Eighty-seven percent of ground-water outflow is accounted for by discharge to Green Pond Brook (62 percent) and the Rockaway River (25 percent). About 11 percent of ground-water outflow is discharge from wells. Less than 2 percent of the ground-water outflow is to Bear Swamp Brook and an unnamed pond (fig. 35).

\section{SUMMARY AND CONCLUSIONS}

Picatinny Arsenal has been a site of the manufacture of explosives since the mid1800's and, in 1908, was designated a U.S. Army Arsenal. The ground-water resources of the arsenal area are affected by numerous point sources of contamination as a result of these activities (Benioff and others, 1991). In response to the contamination of ground water in this area, Picatinny Arsenal, in cooperation with the U.S. Army Armament Research Development and Engineering Center, began a ground-water study with the U.S. Geological Survey. The objectives of this study were to (1) describe the hydrogeologic framework of Picatinny Arsenal and vicinity and (2) construct a valley-wide groundwater-flow model that simulates the ground-water-flow system of a 4.3-mi ${ }^{2}$ area centered on the arsenal. This model integrates all available hydrologic data at Picatinny Arsenal and vicinity into a consistent representation of the flow system.

Ground-water flow in the glacial sediments and bedrock aquifer at Picatinny Arsenal, N. J., was simulated with a modular three-dimensional finite-difference groundwater-flow model (McDonald and Harbaugh, 1988). A sequence of six permeable and three low-permeability layers was represented as aquifers and confining units, respectively. The glacial sediments that consist of layers of gravel, sand, silt, and clay were deposited on folded and faulted Precambrian to Paleozoic rocks during the Wisconsin glaciation.

Most of the model boundaries coincide with the natural hydrologic boundaries of this ground-water system. The upper model boundary at the water table includes areally distributed recharge. Surface-water runoff from the adjacent mountains was simulated as 
Table 5. Simulated steady-state ground-water budget of the glacial sediments and bedrock aquifer at Picatinny Arsenal and vicinity, New Jersey

[Values are in cubic feet per second; --, not applicable]

\begin{tabular}{lcl}
\hline \multicolumn{1}{c}{ Boundary } & In & Out \\
\hline & \multicolumn{2}{l}{-} \\
Recharge & 4.38 & -- \\
Picatinny Lake & 1.92 & -- \\
Valley-side recharge and springs & 3.66 & -- \\
Bear Swamp Brook & 1.80 & .11 \\
Green Pond Brook & .85 & 8.07 \\
Rockaway river & .33 & 3.23 \\
Wells & 1.47 & -- \\
Unnamed pond & -- & .06 \\
Total & 12.94 & 12.94 \\
\end{tabular}


additional recharge (specified fluxes) to the model cells that represent the area along the base of the adjacent mountains (the northwestern and southeastern parts of the modeled area), where the glacial sediments pinch out. Picatinny Lake, the Rockaway River, drainage ditches, Green Pond Brook, and Bear Swamp Brook are represented as headdependent leakage boundaries. The lateral boundaries in the glacial sediments and bedrock at Picatinny Lake and southwest of the Rockaway River are no-flow boundaries. Ground water that does not discharge to Green Pond Brook, Bear Swamp Brook, or the unnamed pond flows down the valley (southwestward) and is assumed to discharge to the Rockaway River. Flow from the bedrock to the glacial sediments at the valley wall was assumed to be negligible and was simulated as a no-flow boundary. The lower boundary, the bottom of the permeable bedrock, is a no-flow boundary.

Calibration of the steady-state model for average hydrologic conditions during 1989-93 was achieved primarily by trial-and-error adjustment of initial estimates of the horizontal and vertical hydraulic conductivities of the permeable and low-permeability layers, respectively. Model calibration was based partly on the comparison of simulated to measured water levels and head differences at well clusters and to streamflow gain or loss from the ground-water system.

Simulation results show that ground-water flow in the glacial sediments and bedrock at Picatinny Arsenal is controlled by the amount and distribution of ground-water recharge and the permeability of the bedrock and the glacial sediments. The principal source of ground water to this region is local precipitation. The low permeability and steep slopes of the adjacent mountains restrict the infiltration of the precipitation to these mountains. Most of the precipitation that falls on the mountains flows overland to their bases and infiltrates the highly permeable glacial sediments. All the precipitation that is not lost to the atmosphere through evapotranspiration, including the precipitation that flows into the ground-water system, eventually flows to either the Rockaway River, Green Pond Brook, or local surface-water bodies.

North of First Street, ground water flows down through the glacial sediments at the base of the mountains and eventually discharges to Green Pond Brook. Ground-waterflow directions at the southern boundary of the arsenal differ from those in the area north of First Street. Ground water near the axis of the southern part of the arsenal in the upper aquifer system is locally affected by seepage from Green Pond Brook at an altitude of 685 $\mathrm{ft}$. At times, Green Pond Brook loses water to the underlying upper aquifer system; this flux of water keeps the water level in the upper system higher than the water level in the deeper system, which is affected by its connection to the Rockaway River at an altitude of $660 \mathrm{ft}$.

Simulation results indicate that the major sources of water to the ground-water system are recharge from precipitation (34 percent of inflow) and runoff from the adjacent mountains ( 28 percent). Bear Swamp Brook, which carries water from uplands outside the 
modeled area, contributes 14 percent of inflow because it is a losing stream through virtually its entire reach. Seepage out of Picatinny Lake constitutes about 15 percent of inflow. Although Green Pond Brook is a gaining stream through most of its length, about 6 percent of inflow is contributed by a few losing reaches. Less than 3 percent of inflow is contributed as seepage from the Rockaway River.

Eighty-seven percent of ground-water outflow is accounted for by discharge to Green Pond Brook (62 percent) and the Rockaway River ( 25 percent). About 11 percent of the ground-water outflow is discharge to wells. Less than 2 percent of the ground-water outflow is to Bear Swamp Brook and an unnamed pond. 


\section{SELECTED REFERENCES}

Bayley, W.S., Salisbury, R.D., and Kummel, H.B., 1914, Raritan [Quadrangle], New Jersey, folio 191 of Geologic atlas of the United States: U. S. Geological Survey, $233 \mathrm{p}$.

Benioff, P.A., Bhattacharyya, M.H., Biang, C., Chiu, S.Y., Miller, S., Patton, T., Pearl, R., Yonk, A., and Yuen, C.R., 1991, Remedial investigation concept plan for Picatinny Arsenal, volume 2: Description of and sampling plans for remedial investigation sites: Argonne, Ill., Environmental Assessment and Information Sciences Division, Argonne National Laboratory, 18 chap.

Drake, A.A., Jr., 1969, Precambrian and lower Potomac geology of the Delaware Valley, New Jersey-Pennsylvania, in Geology of selected areas in New Jersey and eastern Pennsylvania and guidebook of excursions: Geological Society of America and associated societies annual meeting, Atlantic City, New Jersey, November 1969: New Brunswick, N.J., Rutgers University Press, p. 51-132.

Freeze, R.A., and Cherry, J.A., 1979, Groundwater: Englewood Cliffs, N.J., PrenticeHall, 604 p.

Gill, H.E., and Vecchioli, John, 1965, Availability of ground water in Morris County, New Jersey: New Jersey Department of Conservation and Economic Development, Special Report 25, 56 p.

Harte, P.T., Sargent, B.P., and Vowinkel, E.F., 1986, Description and results of test-drilling program at Picatinny Arsenal, New Jersey, 1982-84: U.S. Geological Survey Open-File Report 86-316, 54 p.

Hill, M.C., 1990, Precondition conjugate-gradient 2 (PCG2), a computer program for solving ground-water flow equations: U.S. Geological Survey Water-Resources Investigations Report 90-4048, v. 43 p.

Hill, M.C., Lennon, G.P., Brown, G.A., Hebson, C.S., and Rheaume, S.J., 1992, Geohydrology of, and simulation of ground-water flow in, the valley-fill deposits in the Ramapo River Valley, New Jersey: U.S. Geological Survey Water-Resources Investigations Report 90-4151, 92 p.

Herman, G.C., and Mitchell, J.P., 1991, Bedrock geologic map of the Green Pond Mountain region from Dover to Greenwood Lake, New Jersey: New Jersey Geological Survey, Geologic Map Series 91-2, 3 sheets. 


\section{SELECTED REFERENCES--Continued}

Lacombe, P.J., Sargent, B.P., Harte, P.T., and Vowinkel, E.F., 1986, Determination of geohydrologic framework and extent of ground-water contamination using surface geophysical techniques at Picatinny Arsenal, New Jersey: U.S. Geological Survey Water-Resources Investigations Report 86-4051, 31 p.

Ly ford, F.P., and Cohen, A.J., 1988, Estimation of water available for recharge to sand and gravel aquifers in the glaciated Northeastern United States, in Randall, A.D., and Johnson, A.I., eds., Regional aquifer systems of the United States; the Northeast glacial aquifers--Papers presented at American Water Resources Association Symposium on Monitoring, Modeling, and Mediating Water Quality, Syracuse, New York, May 17-20, 1987: American Water Resources Association Monograph Series No. 11, p. 37-61.

McDonald, M.G., and Harbaugh, A.W., 1988, A modular three-dimensional finitedifference ground-water flow model: U.S. Geological Survey Techniques of Water-Resources Investigations, book 6, chap. A1, 586 p.

Meisler, Harold, 1976, Computer simulation model of the Pleistocene valley-fill permeable layer in southwestern Essex and southeastern Morris Counties, New Jersey: U.S. Geological Survey Water-Resources Investigations 76-25, 69 p., 1 pl.

Morrissey, D.J., Randall, A.D., and Williams, J.H., 1988, Upland runoff as a major source of recharge to stratified drift in the glaciated Northeast, in Randall, A.D., and Johnson, A.I., eds., Regional aquifer systems of the United States; the Northeast glacial aquifers--Papers presented at American Water Resources Association Symposium on Monitoring, Modeling, and Mediating Water Quality, Syracuse, New York, May 17-20, 1987: American Water Resources Association Monograph Series No. 11, p. 17-36.

National Oceanic and Atmospheric Administration, Environmental Data Service, 1980-89, Climatological data, New Jersey: Asheville, N.C., National Climatic Data Center, v. 85-94 [published monthly].

Owens, J.P., and Sohl, N.F., 1969, Shelf and deltaic paleoenvironments in the CretaceousTertiary formations of the New Jersey Coastal Plain, in Geology of selected areas in New Jersey and eastern Pennsylvania and guidebook of excursions: Geological Society of America and associated societies, November 1969, Annual Meeting, Atlantic City, New Jersey: New Brunswick, New Jersey, Rutgers University Press, p. 235-278. 


\section{SELECTED REFERENCES--Continued}

Pettyjohn, W.A., and Henning, Roger, 1979, Preliminary estimate of ground-water recharge rates, related streamflow and water quality in Ohio: Columbus, Ohio, Ohio State University Water Resources Center, Project Completion Report 552, $323 \mathrm{p}$.

Pollock, D.W., 1989, Documentation of computer programs to compute and display pathlines using results from the U.S. Geological Survey modular three-dimensional finite-difference ground-water flow model: U.S. Geological Survey Open-File Report 89-381, 188 p.

Reynolds, R.J., and Brown, G.A., 1984, Hydrogeologic appraisal of a stratified-drift permeable layer near Smyrna, Chenango County, New York: U.S. Geological Survey Water-Resources Investigations Report 84-4029, 53 p., 6 pls.

Sargent, B.P., Fusillo, T.V., Storck, D.A., and Smith, J.A., 1990, Assessment of contamination of ground water and surface water in the area of Building 24, Picatinny Arsenal, New Jersey, 1986-87: U.S. Geological Survey Water-Resources Investigations Report 90-4057, 120 p.

Sargent, B.P., Green, J.W., Harte, P.T., and Vowinkel, E.F., 1986, Ground-water-quality data for Picatinny Arsenal, New Jersey, 1958-85: U.S. Geological Survey OpenFile Report 86-58, 66 p.

Sims, P.K., 1958, Geology and magnetite deposits of Dover District, Morris County, New Jersey: U.S. Geological Survey Professional Paper 287, 162 p.

Stanford, Scott, 1989, Surficial geologic map of the Dover quadrangle, Morris and Sussex Counties, New Jersey: New Jersey Geological Survey, Geological Survey Map 89-2, 1 sheet.

U. S. Department of Housing and Urban Development, Federal Insurance Administration, 1979, Flood insurance study, Township of Rockaway, Morris County, New Jersey: U.S. Department of Housing and Urban Development, $16 \mathrm{p}$.

Wolf, P.E., 1977, The geology and landscapes of New Jersey: New York, Crane, Russak and Company, $351 \mathrm{p}$. 
Table 3. Simulated and measured water levels for wells measured during January $20-22,1993$, for all simulated aquifers, Picatinny Arsenal, New Jersey

[Difference column lists differences between simulated and measured water levels; negative difference indicates that simulated water level is lower than measured water level]

\begin{tabular}{|c|c|c|c|c|c|c|c|}
\hline \multirow[b]{2}{*}{ Well number } & \multirow[b]{2}{*}{ Local name } & \multirow[b]{2}{*}{$\begin{array}{c}\text { Altitude of } \\
\text { land surface } \\
\text { (feet above } \\
\text { sea level) }\end{array}$} & \multirow{2}{*}{\multicolumn{2}{|c|}{$\begin{array}{l}\text { Screened interval } \\
\text { (feet below } \\
\text { land surface) }\end{array}$}} & \multicolumn{3}{|c|}{ Water levels } \\
\hline & & & & & $\begin{array}{l}\text { Simulated } \\
\text { (feet above } \\
\text { sea level) }\end{array}$ & $\begin{array}{c}\text { Measured } \\
\text { (feet above } \\
\text { sea level) }\end{array}$ & $\begin{array}{l}\text { Difference } \\
\text { (feet) }\end{array}$ \\
\hline \multicolumn{8}{|c|}{ Permeable layer I } \\
\hline $27-94$ & $9 B$ & 701.96 & 5.00 & 25.00 & 696.786 & 695.37 & 1.42 \\
\hline $27-95$ & $9 \mathrm{C}$ & 702.11 & 10.00 & $-\quad 20.30$ & 698.052 & 695.63 & 2.42 \\
\hline $27-97$ & 11 & 696.10 & 10.00 & $-\quad 20.30$ & 690.994 & 691.43 & -.44 \\
\hline $27-99$ & $12 \mathrm{~B}$ & 693.62 & 8.90 & $-\quad 19.30$ & 690.048 & 690.69 & -.64 \\
\hline $27-100$ & $12 \mathrm{C}$ & 694.00 & 3.40 & $-\quad 13.40$ & 690.246 & 690.90 & -.65 \\
\hline $27-101$ & 13 & 690.68 & 5.65 & $-\quad 16.20$ & 687.119 & 687.91 & -.79 \\
\hline $27-103$ & 15 & 687.40 & 9.30 & $-\quad 18.30$ & 685.572 & 686.99 & -1.42 \\
\hline $27-104$ & 16 & 692.63 & 10.00 & $-\quad 20.40$ & 683.188 & 684.41 & -1.22 \\
\hline $27-106$ & 18 & 688.26 & 6.25 & $-\quad 16.50$ & 686.695 & 685.77 & .92 \\
\hline $27-231$ & A & 703.83 & 20.3 & $-\quad 40.30$ & 689.334 & 689.96 & -.63 \\
\hline $27-232$ & B & 695.47 & 20.00 & $-\quad 29.00$ & 694.346 & 694.32 & .03 \\
\hline $27-233$ & $\mathrm{C}$ & 690.66 & 10.00 & $\begin{array}{l}-\quad 30.00\end{array}$ & 688.924 & 687.99 & .93 \\
\hline $27-234$ & D & 689.57 & 9.00 & $\begin{array}{l}-\quad 29.00\end{array}$ & 685.525 & 684.87 & .65 \\
\hline $27-235$ & $\mathrm{E}$ & 690.92 & 9.00 & $-\quad 20.00$ & 687.258 & 687.94 & -.68 \\
\hline $27-237$ & $\mathrm{G}$ & 693.28 & 20.00 & - $\quad 29.00$ & 691.313 & 691.66 & -.35 \\
\hline $27-238$ & $\mathrm{H}$ & 699.48 & 12.00 & 32.00 & 691.076 & 690.44 & .64 \\
\hline $27-241$ & $\mathrm{~K}$ & 704.90 & 8.00 & $-\quad 28.00$ & 696.288 & 695.81 & .48 \\
\hline $27-269$ & $12 D$ & 693.98 & 25.00 & $-\quad 30.00$ & 689.642 & 690.57 & -.93 \\
\hline $27-270$ & $12 \mathrm{E}$ & 690.05 & 15.00 & $-\quad 20.00$ & 686.153 & 687.51 & -1.36 \\
\hline $27-339$ & $12 I$ & 691.02 & 8.20 & $-\quad 13.20$ & 689.960 & 691.18 & -1.22 \\
\hline $27-341$ & $12 \mathrm{~F}$ & 692.03 & 9.00 & - $\quad 14.00$ & 689.392 & 690.09 & -.70 \\
\hline $27-951$ & $112-8$ & 695.62 & 15.90 & $-\quad 20.90$ & 690.431 & 689.06 & 1.37 \\
\hline $27-953$ & $112-10$ & 694.30 & 10.70 & $-\quad 15.70$ & 690.345 & 688.67 & 1.67 \\
\hline $27-962$ & $9 \mathrm{E}$ & 702.17 & 14.30 & - $\quad 19.30$ & 696.142 & 694.68 & 1.46 \\
\hline $27-967$ & $34-2$ & 703.30 & 8.00 & - $\quad 18.00$ & 694.200 & 692.75 & 1.45 \\
\hline $27-974$ & $10-3$ & 702.03 & 5.00 & $-\quad 15.00$ & 698.151 & 696.31 & 1.84 \\
\hline 271128 & SB $1-2$ & 690 & 8.00 & $-\quad 18.00$ & 686.418 & 687.82 & -1.40 \\
\hline 271129 & SB $1-3$ & 690.2 & 24.00 & 34.00 & 686.418 & 688.79 & -2.37 \\
\hline 271131 & SB2-2 & 688.4 & 25.00 & $-\quad 35.00$ & 682.596 & 685.14 & -2.54 \\
\hline 271135 & SB3-3 & 698.8 & 21.00 & $-\quad 31.00$ & 683.856 & 687.53 & -3.67 \\
\hline 271201 & $41-16$ & 691.31 & 15.30 & 20.30 & 688.209 & 688.07 & .14 \\
\hline 271210 & $41-23$ & 690.75 & 15.30 & $-\quad 20.30$ & 689.381 & 688.39 & .99 \\
\hline 271221 & $13-2$ & 703.02 & 15.20 & - $\quad 20.20$ & 697.735 & 695.89 & 1.84 \\
\hline 271243 & $1178-1$ & 690.2 & 11.90 & $-\quad 21.90$ & 683.419 & 684.22 & -.80 \\
\hline 271244 & $1179-3$ & 687.8 & 10.20 & $-\quad 20.20$ & 683.780 & 684.97 & -1.19 \\
\hline 271245 & $1179-6$ & 690.6 & 9.80 & 19.80 & 688.437 & 687.79 & .65 \\
\hline 271250 & $1179-4$ & 689.2 & 12.20 & 22.20 & 686.095 & 686.12 & -.03 \\
\hline 271256 & $3548-3$ & 690.1 & 12.20 & 22.20 & 686.781 & 687.37 & -.59 \\
\hline 271258 & $3548-2$ & 690.9 & 3.60 & $-\quad 13.60$ & 687.196 & 687.65 & -.45 \\
\hline 271259 & $1179 \mathrm{~A}-1$ & 688.1 & 12.40 & 22.40 & 684.102 & 684.12 & -.02 \\
\hline
\end{tabular}


Table 3. Simulated and measured water levels for wells measured during January 20 - 22, 1993 , for all simulated aquifers, Picatinny Arsenal, New Jersey--Continued

\begin{tabular}{|c|c|c|c|c|c|c|c|}
\hline \multirow{2}{*}{ Well number } & \multirow[b]{2}{*}{ Local name } & \multirow[b]{2}{*}{$\begin{array}{c}\text { Altitude of } \\
\text { land surface } \\
\text { (feet above } \\
\text { sea level) }\end{array}$} & & & \multicolumn{3}{|c|}{ Water levels } \\
\hline & & & \multicolumn{2}{|c|}{$\begin{array}{l}\text { Screened interval } \\
\text { (feet below } \\
\text { land surface) }\end{array}$} & $\begin{array}{l}\text { Simulated } \\
\text { (feet above } \\
\text { sea level) }\end{array}$ & $\begin{array}{l}\text { Measured } \\
\text { (feet above } \\
\text { sea level) }\end{array}$ & $\begin{array}{l}\text { Difference } \\
\quad \text { (feet) }\end{array}$ \\
\hline $\begin{array}{l}271262 \\
271264 \\
271266 \\
271269 \\
271271\end{array}$ & $\begin{array}{c}1179 \mathrm{~A}-2 \\
1180-2 \\
1179 \mathrm{~A}-3 \\
\mathrm{C}-1 \mathrm{~B} \\
18-1\end{array}$ & $\begin{array}{l}688.1 \\
689.7 \\
688.4 \\
691.4 \\
697.61\end{array}$ & $\begin{array}{r}9.50 \\
10.50 \\
12.50 \\
12.30 \\
10.60\end{array}$ & $\begin{array}{ll}- & 19.50 \\
- & 20.50 \\
- & 22.50 \\
- & 22.30 \\
- & 20.60\end{array}$ & $\begin{array}{l}684.312 \\
684.479 \\
684.442 \\
690.792 \\
691.186\end{array}$ & $\begin{array}{l}684.09 \\
684.49 \\
684.15 \\
689.98 \\
691.76\end{array}$ & $\begin{array}{r}0.22 \\
-.01 \\
.29 \\
.81 \\
. .57\end{array}$ \\
\hline $\begin{array}{l}271272 \\
271273 \\
271276 \\
271277 \\
271278\end{array}$ & $\begin{array}{c}80-1 \\
80-2 \\
70-1 \mathrm{~A} \\
82-1 \\
82-2\end{array}$ & $\begin{array}{l}690.57 \\
690.63 \\
690.12 \\
690.03 \\
690.20\end{array}$ & $\begin{array}{r}24.80 \\
9.40 \\
10.10 \\
12.80 \\
22.90\end{array}$ & $\begin{array}{ll}- & 29.80 \\
- & 14.40 \\
- & 15.10 \\
- & 17.80 \\
- & 27.90\end{array}$ & $\begin{array}{l}685.281 \\
685.280 \\
687.912 \\
686.484 \\
686.484\end{array}$ & $\begin{array}{l}685.56 \\
685.25 \\
688.68 \\
688.54 \\
688.63\end{array}$ & $\begin{array}{r}-.28 \\
.03 \\
-.77 \\
-2.06 \\
-2.15\end{array}$ \\
\hline $\begin{array}{l}271281 \\
271285 \\
271287 \\
271288 \\
271290\end{array}$ & $\begin{array}{c}70-3 \\
\text { WG3-3 } \\
\text { WG9-2 } \\
\text { WG9-3 } \\
36-2\end{array}$ & $\begin{array}{l}691.50 \\
690.71 \\
691.37 \\
691.35 \\
692.26\end{array}$ & $\begin{array}{r}10.00 \\
9.80 \\
23.20 \\
9.50 \\
19.60\end{array}$ & $\begin{array}{ll}- & 15.00 \\
- & 14.80 \\
- & 28.20 \\
- & 14.50 \\
- & 24.60\end{array}$ & $\begin{array}{l}688.648 \\
688.807 \\
688.919 \\
688.918 \\
688.590\end{array}$ & $\begin{array}{l}689.64 \\
689.85 \\
690.10 \\
690.18 \\
690.25\end{array}$ & $\begin{array}{l}-.99 \\
-1.04 \\
-1.18 \\
-1.26 \\
-1.66\end{array}$ \\
\hline $\begin{array}{l}271291 \\
271332 \\
271333 \\
271334 \\
271335\end{array}$ & $\begin{array}{c}36-3 \\
\text { DM-19-1 } \\
\text { DM-19-2 } \\
\text { DM-19-3 } \\
\text { DM-20-1 }\end{array}$ & $\begin{array}{l}692.21 \\
690.1 \\
690.9 \\
690.9 \\
686.3\end{array}$ & $\begin{array}{r}10.90 \\
9.50 \\
9.50 \\
10.00 \\
10.00\end{array}$ & $\begin{array}{ll}- & 15.90 \\
- & 19.50 \\
- & 19.50 \\
- & 20.00 \\
- & 20.00\end{array}$ & $\begin{array}{l}688.591 \\
684.493 \\
684.788 \\
685.935 \\
685.790\end{array}$ & $\begin{array}{l}690.24 \\
684.67 \\
684.52 \\
685.79 \\
685.75\end{array}$ & $\begin{array}{r}-1.65 \\
-.18 \\
.27 \\
.14 \\
.04\end{array}$ \\
\hline $\begin{array}{l}271336 \\
271337 \\
271341 \\
271342 \\
271343\end{array}$ & $\begin{array}{l}\text { DM-20-2 } \\
\text { DM-20-3 } \\
\text { DM-24-1 } \\
\text { DM-25-1 } \\
\text { DM-25-2 }\end{array}$ & $\begin{array}{l}685.4 \\
691.3 \\
685.3 \\
692.8 \\
692.8\end{array}$ & $\begin{array}{r}10.00 \\
10.00 \\
10.00 \\
9.50 \\
9.90\end{array}$ & $\begin{array}{ll}- & 20.00 \\
- & 20.00 \\
- & 20.00 \\
- & 19.80 \\
- & 20.10\end{array}$ & $\begin{array}{l}686.660 \\
688.722 \\
686.035 \\
683.227 \\
684.022\end{array}$ & $\begin{array}{l}685.46 \\
689.41 \\
684.95 \\
686.36 \\
685.63\end{array}$ & $\begin{array}{r}1.20 \\
-.69 \\
1.08 \\
-3.13 \\
-1.61\end{array}$ \\
\hline $\begin{array}{l}271344 \\
271345 \\
271346 \\
271347 \\
271715\end{array}$ & $\begin{array}{l}\text { DM-25-3 } \\
\text { DM-25-4 } \\
\text { DM-25-5 } \\
\text { DM-27-1 } \\
\text { SBF }\end{array}$ & $\begin{array}{l}693.5 \\
695.4 \\
691.9 \\
687.6 \\
694.8\end{array}$ & $\begin{array}{r}9.80 \\
9.50 \\
9.50 \\
10.00 \\
--\end{array}$ & $\begin{array}{cc}- & 19.80 \\
- & 19.50 \\
- & 19.50 \\
- & 20.00 \\
- & --\end{array}$ & $\begin{array}{l}685.433 \\
692.127 \\
686.801 \\
685.162 \\
692.113\end{array}$ & $\begin{array}{l}686.45 \\
691.63 \\
687.80 \\
686.72 \\
690.94\end{array}$ & $\begin{array}{r}-1.02 \\
.50 \\
-1.00 \\
-1.56 \\
1.17\end{array}$ \\
\hline \multicolumn{8}{|c|}{ Permeable layer 2} \\
\hline $\begin{array}{l}27-938 \\
27-941 \\
27-943 \\
271213 \\
271248\end{array}$ & $\begin{array}{c}41-2 \\
41-5 \\
41-9 \\
92-9 \\
1179-1\end{array}$ & $\begin{array}{l}692.58 \\
688.75 \\
690.40 \\
699.94 \\
688.0\end{array}$ & $\begin{array}{l}15.60 \\
12.20 \\
15.80 \\
20.30 \\
40.20\end{array}$ & $\begin{array}{ll}- & 20.60 \\
- & 17.20 \\
- & 20.80 \\
- & 25.30 \\
- & 50.20\end{array}$ & $\begin{array}{l}687.877 \\
688.079 \\
688.137 \\
690.797 \\
684.616\end{array}$ & $\begin{array}{l}687.41 \\
686.28 \\
686.06 \\
690.56 \\
686.36\end{array}$ & $\begin{array}{r}.47 \\
1.80 \\
2.08 \\
.24 \\
-1.74\end{array}$ \\
\hline $\begin{array}{l}271251 \\
271263 \\
271282 \\
271284 \\
271286\end{array}$ & $\begin{array}{c}1179-4 \mathrm{~A} \\
1180-1 \\
70-4 \\
\text { WG3-2 } \\
\text { WG9-1 }\end{array}$ & $\begin{array}{l}689.1 \\
689.1 \\
691.97 \\
690.95 \\
691.40\end{array}$ & $\begin{array}{l}49.40 \\
51.30 \\
21.30 \\
20.30 \\
26.00\end{array}$ & $\begin{array}{ll}- & 59.40 \\
- & 61.30 \\
- & 26.30 \\
- & 25.30 \\
- & 31.00\end{array}$ & $\begin{array}{l}686.332 \\
685.348 \\
688.852 \\
688.996 \\
689.106\end{array}$ & $\begin{array}{l}687.31 \\
687.55 \\
689.62 \\
689.87 \\
690.07\end{array}$ & $\begin{array}{r}-.98 \\
-2.20 \\
-.77 \\
-.87 \\
-.96\end{array}$ \\
\hline
\end{tabular}


Table 3. Simulated and measured water levels for wells measured during January $20-22,1993$, for all simulated aquifers, Picatinny Arsenal, New Jersey--Continued

\begin{tabular}{|c|c|c|c|c|c|c|c|}
\hline \multirow[b]{2}{*}{ Well number } & \multirow[b]{2}{*}{ Local name } & \multirow[b]{2}{*}{$\begin{array}{l}\text { Altitude of } \\
\text { land surface } \\
\text { (feet above } \\
\text { sea level) }\end{array}$} & & & \multicolumn{3}{|c|}{ Water levels } \\
\hline & & & \multicolumn{2}{|c|}{$\begin{array}{c}\text { Screened interval } \\
\text { (feet below } \\
\text { land surface) }\end{array}$} & $\begin{array}{c}\text { Simulated } \\
\text { (feet above } \\
\text { sea level) } \\
\end{array}$ & $\begin{array}{c}\text { Measured } \\
\text { (feet above } \\
\text { sea level) } \\
\end{array}$ & $\begin{array}{c}\text { Difference } \\
\text { (feet) }\end{array}$ \\
\hline \multicolumn{8}{|c|}{ Permeable layer 3} \\
\hline $\begin{array}{l}27-92 \\
27-243 \\
27-249 \\
27-251 \\
27-267\end{array}$ & $\begin{array}{c}8 \\
\text { CAF-2 } \\
65-4 \\
\text { LF-2 } \\
129-\mathrm{OB}\end{array}$ & $\begin{array}{l}712.20 \\
702.74 \\
700.23 \\
693.29 \\
703.38\end{array}$ & $\begin{array}{r}3.30 \\
31.00 \\
30.00 \\
60.00 \\
19.60\end{array}$ & $\begin{array}{ll}- & 13.30 \\
- & 36.00 \\
- & 35.00 \\
- & 65.00 \\
- & 23.20\end{array}$ & $\begin{array}{l}705.876 \\
691.364 \\
691.196 \\
682.749 \\
690.568\end{array}$ & $\begin{array}{l}709.25 \\
692.88 \\
692.44 \\
686.35 \\
691.69\end{array}$ & $\begin{array}{l}-3.37 \\
-1.52 \\
-1.24 \\
-3.60 \\
-1.12\end{array}$ \\
\hline $\begin{array}{l}27-268 \\
27-271 \\
27-304 \\
27-937 \\
27-940\end{array}$ & $\begin{array}{c}151 \\
320 \\
\text { CAF-5 } \\
41-1 \\
41-4\end{array}$ & $\begin{array}{l}694.36 \\
696.61 \\
703.24 \\
692.59 \\
688.61\end{array}$ & $\begin{array}{l}25.00 \\
25.00 \\
24.00 \\
39.60 \\
28.10\end{array}$ & $\begin{array}{ll}- & 30.00 \\
- & 30.00 \\
- & 29.00 \\
- & 44.60 \\
- & 33.10\end{array}$ & $\begin{array}{l}689.688 \\
690.375 \\
691.185 \\
688.664 \\
688.953\end{array}$ & $\begin{array}{l}690.27 \\
689.66 \\
692.50 \\
689.90 \\
686.69\end{array}$ & $\begin{array}{r}-.58 \\
.72 \\
-1.31 \\
-1.24 \\
2.26\end{array}$ \\
\hline $\begin{array}{l}27-942 \\
27-944 \\
27-946 \\
27-947 \\
27-949\end{array}$ & $\begin{array}{l}41-8 \\
112-1 \\
112-3 \\
112-4 \\
112-6\end{array}$ & $\begin{array}{l}690.55 \\
697.24 \\
698.18 \\
698.26 \\
695.59\end{array}$ & $\begin{array}{l}30.80 \\
32.00 \\
46.10 \\
37.00 \\
36.10\end{array}$ & $\begin{array}{ll}- & 35.80 \\
- & 37.00 \\
- & 51.10 \\
- & 42.00 \\
- & 41.10\end{array}$ & $\begin{array}{l}688.728 \\
688.865 \\
689.409 \\
689.400 \\
689.697\end{array}$ & $\begin{array}{l}689.33 \\
689.43 \\
689.62 \\
689.52 \\
689.08\end{array}$ & $\begin{array}{l}-.60 \\
-.57 \\
-.21 \\
-.12 \\
.62\end{array}$ \\
\hline $\begin{array}{l}27-950 \\
27-952 \\
27-954 \\
27-955 \\
27-956\end{array}$ & $\begin{array}{l}112-7 \\
112-9 \\
I-2 \\
92-3 \\
92-4\end{array}$ & $\begin{array}{l}695.66 \\
694.33 \\
693.22 \\
700.22 \\
699.95\end{array}$ & $\begin{array}{l}46.10 \\
31.10 \\
31.90 \\
50.20 \\
38.00\end{array}$ & $\begin{array}{ll}- & 51.10 \\
- & 36.00 \\
- & 36.90 \\
- & 55.20 \\
- & 43.00\end{array}$ & $\begin{array}{l}689.692 \\
689.850 \\
689.554 \\
690.319 \\
690.319\end{array}$ & $\begin{array}{l}689.27 \\
688.88 \\
688.67 \\
691.06 \\
691.02\end{array}$ & $\begin{array}{l}.42 \\
.97 \\
.88 \\
-.74 \\
-.74\end{array}$ \\
\hline $\begin{array}{l}27-957 \\
27-960 \\
27-961 \\
27-963 \\
27-971\end{array}$ & $\begin{array}{c}92-5 \\
\text { CAF-6 } \\
9 \mathrm{D} \\
31-2 \mathrm{~A} \\
39-2\end{array}$ & $\begin{array}{l}699.65 \\
702.21 \\
702.16 \\
702.13 \\
692.39\end{array}$ & $\begin{array}{l}25.90 \\
50.90 \\
26.00 \\
25.90 \\
90.00\end{array}$ & $\begin{array}{lr}- & 30.90 \\
- & 55.90 \\
- & 31.00 \\
- & 30.90 \\
- & 100.00\end{array}$ & $\begin{array}{l}690.315 \\
691.361 \\
692.333 \\
692.075 \\
689.059\end{array}$ & $\begin{array}{l}691.05 \\
692.94 \\
694.83 \\
695.17 \\
689.85\end{array}$ & $\begin{array}{r}-.74 \\
-1.58 \\
-2.50 \\
-3.09 \\
-.79\end{array}$ \\
\hline $\begin{array}{l}271202 \\
271203 \\
271208 \\
271209 \\
271211\end{array}$ & $\begin{array}{c}41-17 \\
41-18 \\
41-21 \\
41-22 \\
92-7\end{array}$ & $\begin{array}{l}691.08 \\
690.94 \\
690.89 \\
690.76 \\
700.04\end{array}$ & $\begin{array}{l}35.20 \\
55.10 \\
53.70 \\
35.60 \\
55.50\end{array}$ & $\begin{array}{ll}- & 40.20 \\
- & 60.10 \\
- & 58.70 \\
- & 40.40 \\
- & 60.50\end{array}$ & $\begin{array}{l}689.111 \\
689.109 \\
688.824 \\
688.833 \\
690.405\end{array}$ & $\begin{array}{l}689.92 \\
688.05 \\
688.63 \\
688.48 \\
690.76\end{array}$ & $\begin{array}{r}-.81 \\
1.06 \\
.19 \\
.35 \\
-.36\end{array}$ \\
\hline $\begin{array}{l}271212 \\
271215 \\
271220 \\
271222 \\
271274\end{array}$ & $\begin{array}{l}92-8 \\
9 \mathrm{G} \\
13-1 \\
24-5 \\
80-3\end{array}$ & $\begin{array}{l}699.94 \\
701.87 \\
703.01 \\
701.13 \\
690.77\end{array}$ & $\begin{array}{l}35.30 \\
35.20 \\
35.60 \\
35.70 \\
37.80\end{array}$ & $\begin{array}{ll}- & 40.30 \\
- & 40.20 \\
- & 40.60 \\
- & 40.70 \\
- & 47.80\end{array}$ & $\begin{array}{l}690.403 \\
692.491 \\
693.148 \\
692.744 \\
688.957\end{array}$ & $\begin{array}{l}690.63 \\
695.35 \\
695.91 \\
695.62 \\
686.32\end{array}$ & $\begin{array}{r}-.23 \\
-2.86 \\
-2.76 \\
-2.88 \\
2.64\end{array}$ \\
\hline $\begin{array}{l}271279 \\
271280 \\
271283 \\
271289 \\
271725\end{array}$ & $\begin{array}{c}82-3 \\
70-2 \\
\text { WG3-1 } \\
36-1 \\
477-1\end{array}$ & $\begin{array}{l}690.87 \\
691.30 \\
690.75 \\
692.37 \\
698.50\end{array}$ & $\begin{array}{l}37.80 \\
34.60 \\
31.80 \\
35.10 \\
24.00\end{array}$ & $\begin{array}{ll}- & 42.80 \\
- & 39.60 \\
- & 36.80 \\
- & 45.10 \\
- & 29.00\end{array}$ & $\begin{array}{l}689.021 \\
689.044 \\
689.155 \\
689.345 \\
692.142\end{array}$ & $\begin{array}{l}688.24 \\
690.04 \\
689.95 \\
690.34 \\
691.63\end{array}$ & $\begin{array}{r}.78 \\
-1.00 \\
-.80 \\
-1.00 \\
.51\end{array}$ \\
\hline 271726 & $436-1$ & 693.41 & 8.00 & $-\quad 13.00$ & 695.014 & 692.05 & 2.96 \\
\hline
\end{tabular}


Table 3. Simulated and measured water levels for wells measured during January $20-22,1993$, for all simulated aquifers, Picatinny Arsenal, New Jersey--Continued

\begin{tabular}{|c|c|c|c|c|c|c|c|}
\hline \multirow[b]{2}{*}{ Well number } & \multirow[b]{2}{*}{ Local name } & \multirow[b]{2}{*}{$\begin{array}{l}\text { Altitude of } \\
\text { land surface } \\
\text { (feet above } \\
\text { sea level) }\end{array}$} & \multirow{2}{*}{\multicolumn{2}{|c|}{$\begin{array}{l}\text { Screened interval } \\
\text { (feet below } \\
\text { land surface) }\end{array}$}} & \multicolumn{3}{|c|}{ Water levels } \\
\hline & & & & & $\begin{array}{l}\text { Simulated } \\
\text { (feet above } \\
\text { sea level) }\end{array}$ & $\begin{array}{l}\text { Measured } \\
\text { (feet above } \\
\text { sea level) }\end{array}$ & $\begin{array}{l}\text { Difference } \\
\text { (feet) }\end{array}$ \\
\hline \multicolumn{8}{|c|}{ Permeable layer 4} \\
\hline $\begin{array}{l}27-252 \\
27-281 \\
271252 \\
271265 \\
271268\end{array}$ & $\begin{array}{c}\text { LF-3 } \\
\mathrm{H}-3(\mathrm{M}) \\
1179-9 \mathrm{~B} \\
1180-2 \mathrm{~A} \\
\mathrm{C}-1 \mathrm{~A}\end{array}$ & $\begin{array}{l}693.08 \\
699.16 \\
689.20 \\
689.2 \\
691.7\end{array}$ & $\begin{array}{r}152.00 \\
115.00 \\
141.00 \\
124.00 \\
77.20\end{array}$ & $\begin{array}{l}-\quad 157.00 \\
-\quad 125.00 \\
-\quad 151.00 \\
-\quad 134.00 \\
-\quad 87.20\end{array}$ & $\begin{array}{l}679.499 \\
689.796 \\
684.378 \\
684.957 \\
687.715\end{array}$ & $\begin{array}{l}679.50 \\
690.61 \\
680.54 \\
681.48 \\
689.99\end{array}$ & $\begin{array}{r}-0.00 \\
-.81 \\
3.84 \\
3.48 \\
-2.27\end{array}$ \\
\hline \multicolumn{8}{|c|}{ Permeable layer 5} \\
\hline $\begin{array}{l}27-81 \\
27-82 \\
27-84 \\
27-86 \\
27-87\end{array}$ & $\begin{array}{c}129 \\
130 \\
430 \mathrm{~A} \\
410 \\
305 \mathrm{~A}\end{array}$ & $\begin{array}{l}704.05 \\
701.59 \\
701.41 \\
710.98 \\
695.81\end{array}$ & $\begin{array}{r}98.00 \\
102.00 \\
62.00 \\
75.00 \\
70.80\end{array}$ & $\begin{array}{rr}- & 113.00 \\
- & 117.00 \\
- & 82.00 \\
- & 85.00 \\
- & 90.80\end{array}$ & $\begin{array}{l}687.627 \\
689.492 \\
691.600 \\
687.609 \\
689.647\end{array}$ & $\begin{array}{l}689.79 \\
688.09 \\
693.30 \\
690.43 \\
689.62\end{array}$ & $\begin{array}{r}-2.16 \\
1.40 \\
-1.70 \\
-2.82 \\
.03\end{array}$ \\
\hline $\begin{array}{l}27-244 \\
27-245 \\
27-247 \\
27-256 \\
27-276\end{array}$ & $\begin{array}{c}\text { CAF-3 } \\
\text { CAF-4 } \\
65-2 \\
507 \mathrm{~B} \\
178\end{array}$ & $\begin{array}{l}702.80 \\
702.91 \\
700.00 \\
731.63 \\
698.90\end{array}$ & $\begin{array}{r}123.00 \\
168.00 \\
201.00 \\
70.00 \\
64.00\end{array}$ & $\begin{array}{rr}- & 128.00 \\
- & 173.00 \\
- & 206.00 \\
- & 80.00 \\
- & 74.00\end{array}$ & $\begin{array}{l}689.574 \\
689.577 \\
689.736 \\
700.512 \\
689.528\end{array}$ & $\begin{array}{l}690.51 \\
690.46 \\
689.59 \\
702.07 \\
690.30\end{array}$ & $\begin{array}{r}-.94 \\
-.88 \\
.15 \\
-1.56 \\
-.77\end{array}$ \\
\hline $\begin{array}{l}27-278 \\
27-307 \\
27-969 \\
27-970 \\
27-973\end{array}$ & $\begin{array}{c}176-\mathrm{SH} \\
\mathrm{DH}-3 \\
10-4 \\
39-1 \\
95-2\end{array}$ & $\begin{array}{l}689.31 \\
690.47 \\
701.93 \\
692.68 \\
695.17\end{array}$ & $\begin{array}{r}50.00 \\
46.00 \\
85.50 \\
195.00 \\
190.00\end{array}$ & $\begin{array}{lr}- & 60.00 \\
- & 51.00 \\
- & 95.50 \\
- & 205.00 \\
- & 200.00\end{array}$ & $\begin{array}{l}689.907 \\
689.356 \\
689.554 \\
689.316 \\
689.534\end{array}$ & $\begin{array}{l}690.17 \\
690.46 \\
694.09 \\
689.63 \\
690.97\end{array}$ & $\begin{array}{r}-.26 \\
-1.10 \\
-4.54 \\
-.31 \\
-1.44\end{array}$ \\
\hline $\begin{array}{l}271130 \\
271134\end{array}$ & $\begin{array}{c}\text { SB2-1A } \\
\text { SB3-2 }\end{array}$ & $\begin{array}{l}688 \\
699.5\end{array}$ & $\begin{array}{l}158.00 \\
170.00\end{array}$ & $\begin{array}{ll}- & 168.00 \\
- & 180.00\end{array}$ & $\begin{array}{l}678.229 \\
679.797\end{array}$ & $\begin{array}{l}677.88 \\
679.62\end{array}$ & $\begin{array}{l}.35 \\
.18\end{array}$ \\
\hline \multicolumn{8}{|c|}{ Permeable layer 6} \\
\hline $\begin{array}{l}27-83 \\
27-242 \\
27-246 \\
27-250 \\
27-277\end{array}$ & $\begin{array}{c}302 \mathrm{D} \\
\text { CAF-1 } \\
65-1 \\
\text { LF-1 } \\
176-1\end{array}$ & $\begin{array}{l}697.02 \\
702.72 \\
700.27 \\
692.85 \\
689.45\end{array}$ & $\begin{array}{l}110.00 \\
253.00 \\
267.00 \\
325.00 \\
275.00\end{array}$ & $\begin{array}{ll}- & 403.00 \\
- & 268.00 \\
- & 287.00 \\
- & 345.00 \\
- & 305.00\end{array}$ & $\begin{array}{l}689.651 \\
689.513 \\
689.660 \\
679.450 \\
689.883\end{array}$ & $\begin{array}{l}689.05 \\
689.59 \\
689.65 \\
676.06 \\
690.46\end{array}$ & $\begin{array}{r}.60 \\
-.08 \\
.01 \\
3.39 \\
-.58\end{array}$ \\
\hline $\begin{array}{l}27-280 \\
27-968 \\
121133\end{array}$ & $\begin{array}{l}\mathrm{H}-2(\mathrm{D}) \\
10-3 \mathrm{~A} \\
\text { SB3-2 }\end{array}$ & $\begin{array}{l}699.23 \\
701.88 \\
688.8\end{array}$ & $\begin{array}{l}203.00 \\
249.00 \\
243.00\end{array}$ & $\begin{array}{l}-\quad 223.00 \\
-\quad 264.00 \\
-\quad 253.00\end{array}$ & $\begin{array}{l}689.601 \\
689.508 \\
678.118\end{array}$ & $\begin{array}{l}689.50 \\
701.68 \\
676.21 \\
\end{array}$ & $\begin{array}{r}.10 \\
-12.17 \\
1.91 \\
\end{array}$ \\
\hline
\end{tabular}




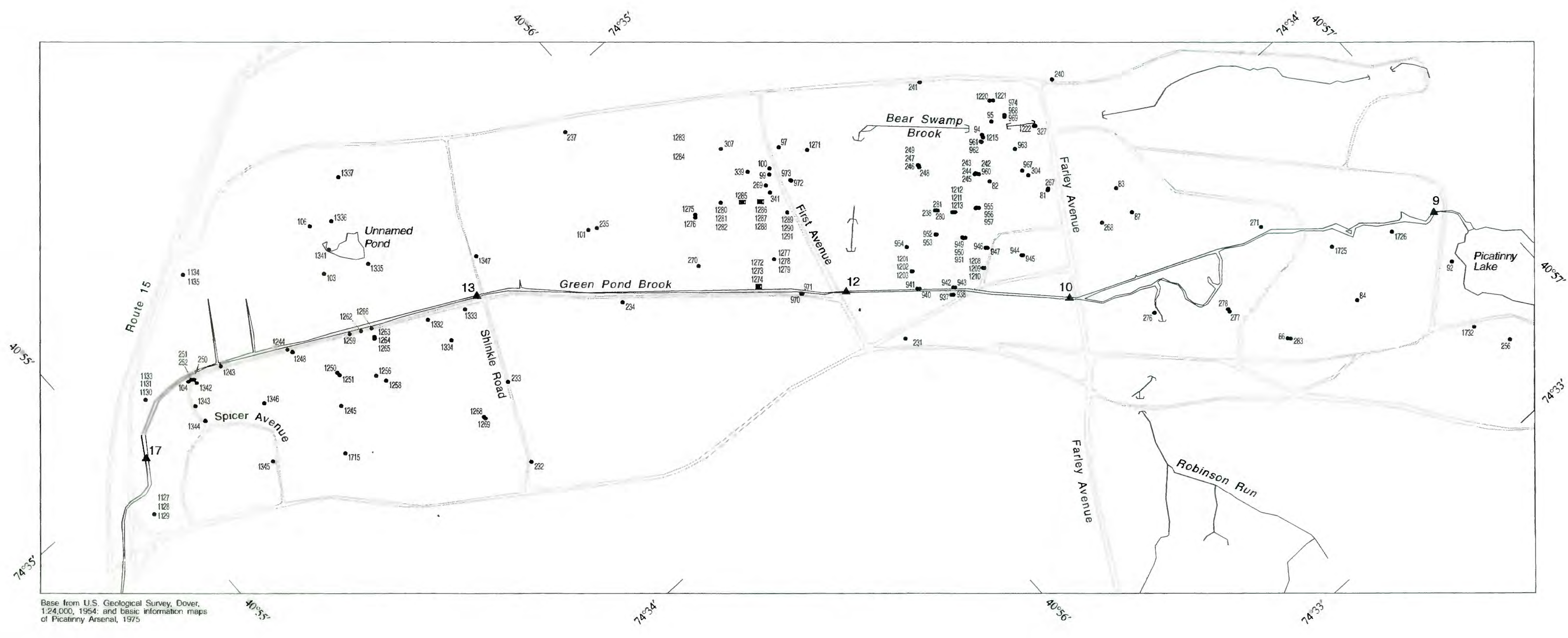

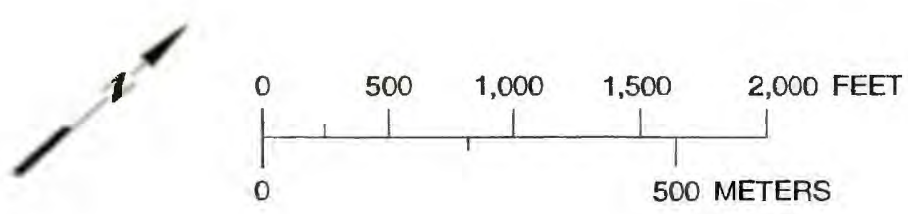

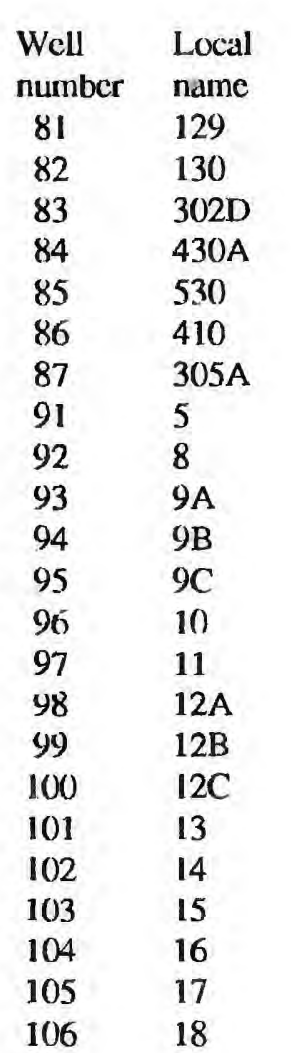

$\begin{array}{ll}\begin{array}{l}\text { Well } \\ \text { number }\end{array} & \text { Local } \\ 256 & \text { name } \\ 257 & 507 \mathrm{~B} \\ 261 & \text { DH-8 } \\ 267 & 129-\mathrm{OB} \\ 268 & 151 \\ 269 & 12 \mathrm{D} \\ 270 & 12 \mathrm{E} \\ 271 & 320 \\ 276 & 178 \\ 277 & 176-1 \\ 278 & 176-\mathrm{SH} \\ 280 & \text { H-2(D) } \\ 281 & \text { H-3(M) } \\ 282 & \text { H-1(S) } \\ 283 & 410-\mathrm{OBS} \\ 304 & \text { CAF-5 } \\ 307 & \text { DH-3 } \\ 326 & 10-2 \\ 327 & 24-1 \\ 328 & 31-4 \\ 329 & 31-2 \\ 330 & 31-3 \mathrm{~A} \\ 331 & 34-1\end{array}$

$\begin{array}{ll}\begin{array}{ll}\text { Well } \\ \text { number }\end{array} & \text { Local } \\ 332 & 112 \\ 333 & 130-3 \\ 334 & 92-1 \\ 335 & 92-2 \\ 336 & 31-1 \\ 337 & 64-1 \\ 338 & 12 \mathrm{~J} \\ 339 & 12 \mathrm{I} \\ 340 & 12 \mathrm{H} \\ 341 & 12 \mathrm{~F} \\ 342 & 12 \mathrm{G} \\ 937 & 41-1 \\ 938 & 41-2 \\ 939 & 41-3 \\ 940 & 41-4 \\ 941 & 41-5 \\ 942 & 41-8 \\ 943 & 41-9 \\ 944 & 112-1 \\ 945 & 112-2 \\ 946 & 112-3 \\ 947 & 112-4 \\ 948 & 112-5\end{array}$

$\begin{array}{ll}\begin{array}{l}\text { Well } \\ \text { number }\end{array} & \text { Local } \\ 949 & \text { name } \\ 942-6 \\ 950 & 112-7 \\ 951 & 112-8 \\ 952 & 112-9 \\ 953 & 112-10 \\ 954 & \mathrm{I}-2 \\ 955 & 92-3 \\ 956 & 92-4 \\ 957 & 92-5 \\ 958 & 111-1 \\ 959 & 111-2 \\ 960 & \mathrm{CAF}-6 \\ 961 & 9 \mathrm{D} \\ 962 & 9 \mathrm{E} \\ 963 & 31-2 \mathrm{~A} \\ 964 & 31-5 \\ 965 & 31-6 \\ 966 & 31-7 \\ 967 & 34-2 \\ 968 & 10-3 \mathrm{~A} \\ 969 & 10-4 \\ 970 & 39-1 \\ 971 & 39-2\end{array}$

$\begin{array}{ll}\text { Well } & \text { Local } \\ \text { number } & \text { name } \\ 972 & 95-1 \\ 973 & 95-2 \\ 974 & 10-3 \\ 1127 & \text { SB1-1A } \\ 1128 & \text { SB1-2 } \\ 1129 & \text { SB1-3 } \\ 1130 & \text { SB2-1A } \\ 1131 & \text { SB2-2 } \\ 1132 & \text { SB3-1A } \\ 1133 & \text { SB2-3 } \\ 1134 & \text { SB3-2 } \\ 1135 & \text { SB3-3 } \\ 1152 & 1179-4 B \\ 1199 & 41-10 \\ 1200 & 41-11 \\ 1201 & 41-16 \\ 1202 & 41-17 \\ 1203 & 41-18 \\ 1204 & 41-12 \\ 1205 & 41-13 \\ 1206 & 41-14 \\ 1207 & 41-15 \\ 1208 & 41-21\end{array}$

$\begin{array}{ll}\text { Well } & \text { Local } \\ \text { number } & \text { name } \\ 1209 & 41-22 \\ 1210 & 41-23 \\ 1211 & 92-7 \\ 1212 & 92-8 \\ 1213 & 92-9 \\ 1214 & \text { CAF-7 } \\ 1215 & 9 \mathrm{G} \\ 1216 & 9 \mathrm{H} \\ 1217 & 92-10 \\ 1218 & 92-11 \\ 1219 & 92-12 \\ 1220 & 13-1 \\ 1221 & 13-2 \\ 1222 & 24-5 \\ 1243 & 1178-1 \\ 1244 & 1179-3 \\ 1245 & 1199-6 \\ 1246 & 1179-5 \\ 1247 & 1179-7 \\ 1248 & 1179-1 \\ 1249 & 1179-2 \\ 1250 & 1179-4 \\ 1251 & 1179-4 \mathrm{~A}\end{array}$

$\begin{array}{ll}\text { Well } & \text { Local } \\ \text { number } & \text { name } \\ 1253 & 1179 \mathrm{D}-1 \\ 1254 & 1181-3 \\ 1255 & 1179 \mathrm{D}-2 \\ 1256 & 3548-3 \\ 1257 & 181-2 \\ 1258 & 3548-2 \\ 1259 & 1179 \mathrm{~A}-1 \\ 1260 & 3548-1 \\ 1261 & 1181-1 \\ 1262 & 1179 \mathrm{~A}-2 \\ 1263 & 1180-1 \\ 1264 & 1180-2 \\ 1265 & 1180-2 \mathrm{~A} \\ 1266 & 1179 \mathrm{~A}-3 \\ 1267 & 1180-3 \\ 1268 & \mathrm{C}-1 \mathrm{~A} \\ 1269 & \mathrm{C}-1 \mathrm{~B} \\ 1271 & 18-1 \\ 1272 & 80-1 \\ 1273 & 80-2 \\ 1274 & 80-3 \\ 1275 & 70-1 \\ 1276 & 70-1 \mathrm{~A}\end{array}$

$\begin{array}{lll}\text { Local } & \text { Well } & \text { Local } \\ \text { name } & \text { number } & \text { name } \\ 82-1 & 1329 & \text { DM-17-1 } \\ 82-2 & 1330 & \text { DM-17-2 } \\ 82-3 & 1331 & \text { DM-17-3 } \\ 70-2 & 1332 & \text { DM-19-1 } \\ 70-3 & 1333 & \text { DM-19-2 } \\ 70-4 & 1334 & \text { DM-19-3 } \\ \text { WG3-1 } & 1335 & \text { DM-20-1 } \\ \text { WG3-2 } & 1336 & \text { DM-20-2 } \\ \text { WG3-3 } & 1337 & \text { DM-20-3 } \\ \text { WG9-1 } & 1338 & \text { DM-23-1 } \\ \text { WG9-2 } & 1339 & \text { DM-23-2 } \\ \text { WG9-3 } & 1340 & \text { DM-23-3 } \\ \text { 36-1 } & 1341 & \text { DM-24-1 } \\ \text { 36-2 } & 1342 & \text { DM-25-1 } \\ \text { 36-3 } & 1343 & \text { DM-25-2 } \\ \text { WG11-1 } & 1344 & \text { DM-25-3 } \\ \text { WG11-2 } & 1345 & \text { DM-25-4 } \\ \text { WG11-3 } & 1346 & \text { DM-25-5 } \\ \text { 95-3 } & 1347 & \text { DM-27-1 } \\ \text { 95-4 } & 1715 & \text { SBF } \\ \text { DM-6-1 } & 1725 & 477-1 \\ \text { DM-6-2 } & 1726 & 436-1 \\ \text { DM-6-3 } & 1732 & \text { 506-1 }\end{array}$

LOCATION OF STREAMFLOW-MEASUREMENT SITES, JANUARY 19 AND 20, 1993, AND WELLS USED TO CALIBRATE THE VALLEY-WIDE GROUND-WATER-FLOW MODEL, PICATINNY ARSENAL, NEW JERSEY 